\title{
Nanofluids in the Service of High Voltage Transformers: Breakdown Properties of Transformer Oils with Nanoparticles, a Review
}

\author{
Jacek Fal ${ }^{1}{ }^{\mathbb{D}}$, Omid Mahian $^{2}$ and Gaweł Żyła ${ }^{1, * \mathbb{C}}$ \\ 1 Department of Physics and Medical Engineering, Rzeszow University of Technology, 35-959 Rzeszow, \\ Poland; jacekfal@prz.edu.pl \\ 2 Center for Advanced Technologies, Ferdowsi University of Mashhad, 91775-1111 Mashhad, Iran; \\ omid.mahian@gmail.com \\ * Correspondence: gzyla@prz.edu.pl
}

Received: 3 October 2018; Accepted: 23 October 2018; Published: 28 October 2018

\begin{abstract}
The continuous development of electrical systems and high voltage transformers builds the need for looking for new insulating media or to improve the insulating properties of commercially available transformer oils (TO) by various modification techniques. One of these techniques is the modification of existing mineral oils by the addition of different types of nanoparticles in various concentrations. These types of materials, suspensions of nanoparticles called nanofluids, have found numerous applications in the energy industry, especially in heat exchanger systems and solar cells. Much research has been done on attempts to replace mineral oils (MO), which are harmful for the environment, with natural ester oils (NE), but to make this possible, it is necessary to improve the insulating properties of these oils, for example by adding nanoparticles. This paper presents an extensive overview of the insulating properties; including for AC, DC and the lightning impulse breakdown voltage; for both mineral and natural ester oils containing various type of nanoparticles (NP). It is presented that the use of nanofluids could improve the efficiency of existing high voltage infrastructures with a low financial cost.
\end{abstract}

Keywords: breakdown voltage; lightning breakdown voltage; nanofluids; insulating properties

\section{Introduction}

At the end of the 20th Century, Choi and Eastman showed that the thermal conductivity of conventional liquids could be enhanced by suspending nanoparticles (NP) in them; they called this type of dispersion a "nanofluid" [1]. Nanofluids are two-phase mixtures where the solid phase is comprised of nanoparticles with sizes less than $100 \mathrm{~nm}$. After 1995, a large amount of research was done on nanofluids (NF). Figure 1 shows the significant increase in the number of papers on nanofluids, and citations to published articles, that has occurred since then. The studies on nanofluids can be classified into different groups, such as investigations into preparation and the measuring of properties, as well as research into different applications in engineering, sciences and medicine. Since instability has always been one of the main challenges in the implementation of nanofluids, scientists have attempted continuously to improve the preparation techniques to have more stable nanofluids [2-6]. Most of the industrial applications of nanofluids are correlated with their higher effective thermal conductivity compared to common liquids; therefore, heat transfer characteristics of nanofluids have been the subject of many experimental and theoretical studies [7-23]. 

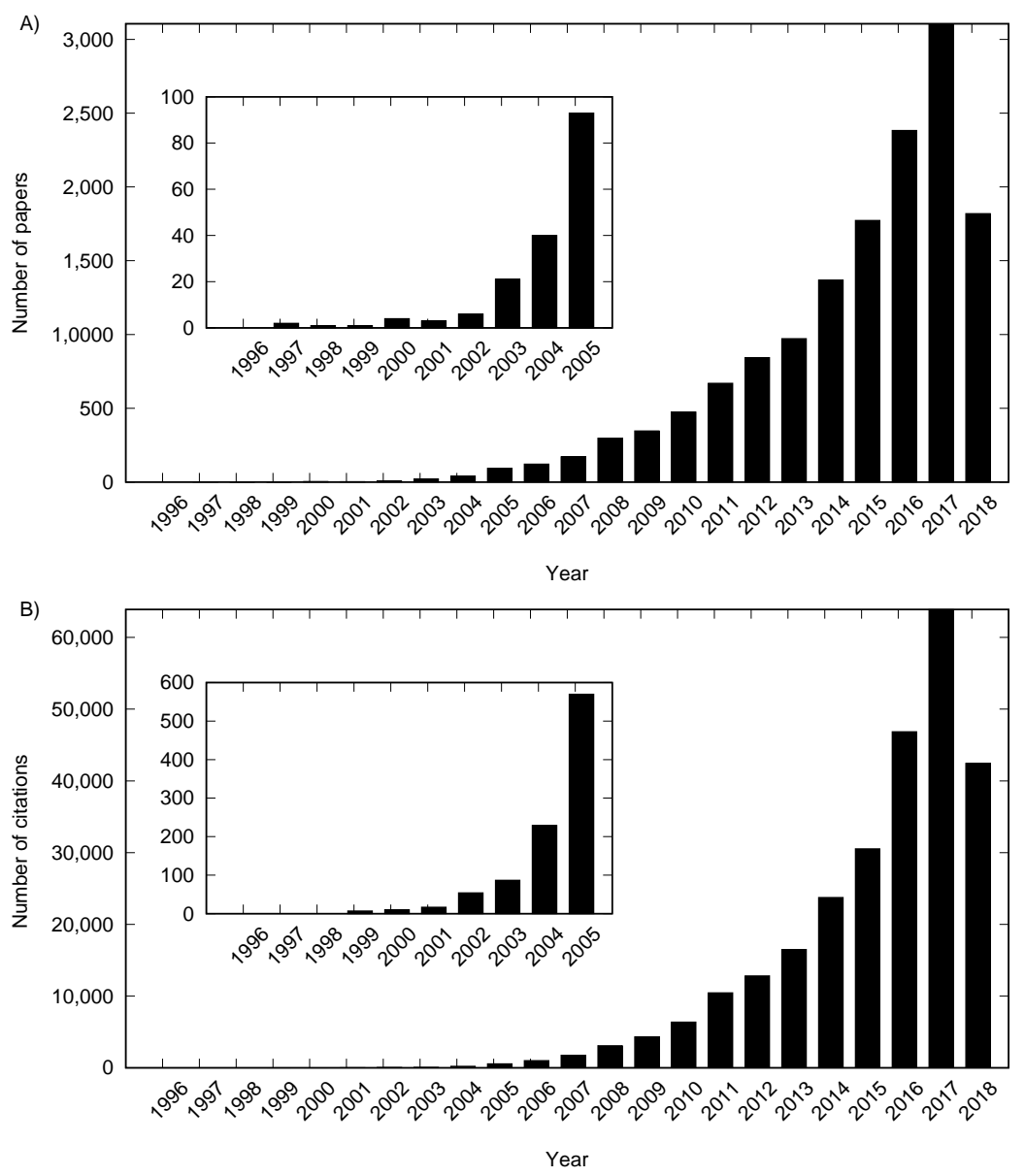

Figure 1. Number of (A) papers and (B) citation of papers with the word "nanofluid" or "nanofluids" in the title, abstract or keywords. Based on Web of Science as of 7 August 2018.

Moreover, the required pumping power in thermal systems depends on rheological properties; therefore, the rheological properties should also be evaluated to have a perfect design [24-30]. Researchers have also investigated the optical specifications [31-33], surface tension and wetting behavior [34] and electrical properties of nanofluids [35-39] due to their importance in the design of solar energy and electronic-based devices.

The other group of studies on nanofluids deals with the applications [40-43]. In recent years, scholars have focused on replacing fossil fuel-based systems by renewable energy based systems such as solar collectors and photovoltaic panels as a solution to air pollution and the global warming crisis, on the one hand, and the shortage of fossil fuel sources, on the other hand. Therefore, it would be worthy to increase the efficiency and performance of such systems. Adding nanoparticles to conventional working fluids might be used as a passive technique to ameliorate the performance of the target systems. Mahian et al. [44] evaluated the potential of nanofluids for efficiency enhancement of various solar energy systems, especially solar collectors. They concluded that nanofluids are mostly (not always) helpful to improve the performance of solar energy devices. Recently, many research studies have been done on the application of nanofluids in renewable energy systems; here, some of them are reviewed. Kim et al. [45] investigated experimentally the performance of a U-tube solar collector where the working fluid was alumina/water nanofluid. It was found that using nanofluid with a volume concentration of $1 \%$ provides a higher efficiency compared to the concentration of $1.5 \%$. Moreover, they found that to achieve the maximum efficiency, alumina nanoparticles with the smallest size should be added to the base fluid (BF). The results indicated that efficiency decreases by $5.3 \%$ with the increase of nanoparticle size from $20 \mathrm{~nm}-100 \mathrm{~nm}$. Loni et al. [46] theoretically studied 
the potential of oil-based nanofluids containing different nanoparticles, including $\mathrm{Al}_{2} \mathrm{O}_{3}, \mathrm{Cu}, \mathrm{SiO}_{2}$ and $\mathrm{TiO}_{2}$ nanoparticles, on the performance of a dish concentrator having a cylindrical cavity receiver. They concluded that adding nanoparticles is advantageous from the second law of thermodynamics viewpoint, but it has a negative effect on the thermal efficiency of the system. Copper nanoparticles were introduced as the best option for adding to the base liquid. Hassani et al. [47] reported the usefulness of nanofluids in the performance enhancement of hybrid photovoltaic and thermal solar (PV/T) systems. Mahian et al. [48] showed that adding nanoparticles to the working fluid flowing in a heat exchanger coupled with a single slope solar still can enhance both the energy and exergy efficiencies of the solar still, although the amount of enhancement is negligible. Besides renewable energy systems, nanofluids have been employed efficiently to modify the performance of thermal systems. Various types of heat exchangers such as heat pipes, shell and tube, double pipe and plate are widely used in industries such as aerospace, food, automobile, air conditioning and electronic devices [49]. For instance, Hosseinian et al. [50] experimentally studied the effects of MWCNT-water nanofluid at three mass fractions (mas fr) including $0.04,0.17$ and $0.25 \%$ on the heat transfer rate from a double pipe heat exchanger that was under vibration. They found that vibration is effective in the decrease of sedimentation of nanoparticles on the tube surface. Moreover, the thermal analysis showed that using nanofluids with a mass fraction of $0.04 \%$ and applying the maximum value of vibration $\left(9 \mathrm{~ms}^{-2}\right)$ can enhance the heat transfer coefficient by $100 \%$. Xing et al. [51] investigated the performance of a vertical pulsating heat pipe using MWCNT-based nanofluids. They found that the thermal resistance of the water-based heat pipe was $34 \%$ higher than that of the nanofluid-based heat pipe (with a mass fraction of $0.1 \mathrm{wt} \%$ ), so nanofluids can be suggested as a suitable option to enhance the heat pipe efficiency. Furthermore, Sarafraz et al. [52] experimentally investigated a plate heat exchanger using $\mathrm{CuO} /$ water nanofluid (concentrations of $0.1,0.2,0.3$ and $0.4 \mathrm{wt} \%$ ), where vibration was applied to reduce deposition of nanoparticles. They found that nanofluid at a mass fraction of $0.3 \%$ provided the maximum rate of heat transfer. Moreover, vibration intensifies the heat transfer. Shahrul et al. [53] evaluated the performance of a shell and tube heat exchanger using different water-based nanofluids. They reported that the values of highest heat transfer coefficient were enhanced by 50,15 and $9 \%$ for $\mathrm{ZnO}, \mathrm{Al}_{2} \mathrm{O}_{3}$ and $\mathrm{SiO}_{2}$ nanoparticles, respectively, compared to the base fluid. These results reveal that the thermal conductivity of nanoparticles plays a crucial role in heat transfer enhancement of heat exchangers as $\mathrm{ZnO}$ nanoparticles have higher thermal conductivity than $\mathrm{Al}_{2} \mathrm{O}_{3}$ and $\mathrm{SiO}_{2}$ nanoparticles.

In the above, a brief review of nanofluid applications in different energy systems was presented. The other possible application of nanofluids is in electrical equipment such as alternating current (AC) transformers, direct current (DC) transmission systems, converter transformers [54] or traction station/supply where DC is used. Insulation materials for all these systems are very similar or even the same, but with differences in their configuration [55]. Due to this, investigations in both AC and DC breakdown voltage (BDV) have been conducted by researchers. The DC BDV test also can be performed instead AC BDV, if we use DC voltage with a value equal to the AC voltage peak [56]. The advantage of using the DC to breakdown test is that the testing voltage is reached very fast and it is constant, opposite to the AC voltage, where the peak value is available only for a short period of time during one cycle. Additionally, DC is safer from the human health point of view [57].

Energy consumption is growing day by day because of population growth and the industrialization of human life. Accordingly, researchers are motivated to find novel solutions to minimize the energy usage. Indeed, electrical systems are one of the main targets for consumption optimization. Primom et al. [58] gave a literature overview related to the utilization of nanofluids in high voltage transformers. They considered such properties of nanofluids based on transformer oils such as breakdown voltage, streamer propagation, partial discharge, thermal properties and factors affecting it based on the chosen articles.

The primary goal of this review paper is to extend, order and systematize knowledge on the breakdown voltage in the context of the application of nanofluids in high voltage transformers. 
This kind of application could improve the efficiency of existing high voltage infrastructure with low financial cost and without any significant changes in actual working systems.

\section{Methods of Measurements}

Breakdown voltage is one of the most important properties of insulating oils used in high voltage transformers. This parameter allows one to define the ability of transformer oil to be used as an insulating medium in electrical devices. The breakdown voltage test can also be used for the determination of impurities in transformer oils such as moisture, cellulose fibers, conducting particles or other contaminants. The presence of these impurities could decrease the breakdown voltage of transformer oils. On the other hand, the high values of BDV tests are not proof that the sample contains no impurities. It is possible that the concentration of contaminants is not enough to cause degradation of the insulating properties. Measurements of transformer oils breakdown voltage are mainly conducted according to two types of standards, The American Society for Testing and Materials (ASTM) and the International Electrotechnical Commission (IEC). ASTM introduced two standards for measuring BDV values: the first is ASTM D1816 [59], and the second is ASTM D877 [60]. For natural ester oils, the ASTM D6871 [61] standard was introduced, which refers to both previously mentioned standards. The main difference between them is in the shape of the electrodes used in the experiments. IEC presented one standard, which is IEC 6015 [62]. All standards, in detail, show test methods for measuring the breakdown voltage of insulating oils. The main differences in test procedures between each standard are presented in Table 1.

Table 1. Comparison of BDV measuring standards [59,60,62].

\begin{tabular}{cccc}
\hline & \multicolumn{3}{c}{ Standards } \\
\cline { 2 - 4 } & ASTM D1816 & ASTM D 877 & IEC 60156 \\
\hline Electrodes' shape & sphere-capped plate & plate & spherical or spherically-capped \\
\hline Electrodes' material & brass & brass & brass or steel \\
\hline Gap (mm) & 2 or 1 & 2.54 & 2.5 \\
\hline Test temperature & & room temperature & $2 \mathrm{kV} / \mathrm{s}$ \\
\hline Rate of voltage rise & $0.5 \mathrm{kV} / \mathrm{s}$ & $3 \mathrm{kV} / \mathrm{s}$ & $1-5$ different samples \\
\hline Number of sequence & 5 & 5 & 20 \\
\hline Time between BDV (s) & $60-90$ & 60 & 2 \\
\hline $\begin{array}{c}\text { Time between filling and } \\
\text { start of testing (min) }\end{array}$ & $3-5$ & $2-3$ & \\
\hline
\end{tabular}

Another important examination for insulating transformer oils is lightning impulse breakdown voltage (LI BDV), which tests the ability of transformer oil to withstand impulse electric stress. In contrast to the BDV test, LI BDV is less dependent on contaminants that can be found in transformer oils. Measurements procedures for LI BDV are also described in detail by two standard organizations, ASTM and IEC, which introduced the following norms: ASTM D3300 [63] and IEC 60897 [64]. The main assumptions and comparison of both standards are summarized in Table 2.

The notation of concentration in the paper is the same as in the source papers, where authors, due to a lack of uniformity in concentration notation, use various units to describe concentrations of samples. 
Table 2. Comparison of LI BDV measuring standards [63,64].

\begin{tabular}{ccc}
\hline & \multicolumn{2}{c}{ Standards } \\
\cline { 2 - 3 } & ASTM D3300 & IEC 60897 \\
\hline Electrodes' shape & point to sphere or sphere to sphere & point to sphere \\
Electrodes' material & steel or brass sphere and steel point & steel \\
Gap (mm) & 25.4 or 3.8 & $10-25$ \\
Test temperature & room temperature & $15-30{ }^{\circ} \mathrm{C}$ \\
Number of sequence & 5 & 5 \\
Time between filling and start of testing $(\mathrm{min})$ & 2 & 5 \\
\hline
\end{tabular}

\section{Breakdown Voltage of Nanofluids}

Researchers and engineers are interested in improvement of the insulating properties of the breakdown voltage of transformer oils. Many attempts have been made to increase breakdown voltage in transformer oils by the addition of various types of nanoparticles with and without surfactants. Furthermore, natural oils have been tested as a more environmentally-friendly alternative to mineral oils. The most often used nanoparticles are oxides of metals, carbon and nitrides, as presented in the following sections.

\subsection{Iron Oxide Nanoparticles}

One of the most widely-used group of materials is iron oxide nanoparticles, which are added in various concentrations to increase the BDV of different insulating oils. Du et al. [65] conducted studies on the AC breakdown voltage properties of transformer oil containing $\mathrm{Fe}_{3} \mathrm{O}_{4}$ nanoparticles with concentrations in the range of $0.05 \mathrm{~g} / \mathrm{L}-0.30 \mathrm{~g} / \mathrm{L}$ and the addition of $0.15 \mathrm{ppm}$ of hexadecyl trimethyl ammonium bromide (CTAB) $(0.15 \mathrm{~g})$ as a surfactant. The average size of nanoparticles was $10 \mathrm{~nm}$. They observed initial improvement in AC BDV up to a 100-ppm load of nanoparticles, and it was about $10 \%(55 \mathrm{kV})$. Above this concentration, the value of AC BDV is decreasing, even below $50 \mathrm{kV}$, which is the AC BDV value of pure transformer oil. The nanofluids based on vegetable oils (VO) and iron oxide nanoparticles were investigated by $\mathrm{Li}$ et al. [66]. The stability of the nano-suspension was checked by the natural sedimentation method. The obtained results show that the mean breakdown voltage of vegetable oil with dispersed nanoparticles was $20 \%$ higher than pure oil.

Peppas et al. [67] studied nanofluids based on natural ester oil and $\mathrm{Fe}_{3} \mathrm{O}_{4}$ nanoparticles with an average diameter less than $50 \mathrm{~nm}$ with the surface modified by oleic acid (OA). Measurements were conducted according to the IEC standard, with a $2 \mathrm{kV} / \mathrm{s}$ rising rate in voltage. They compared the AC breakdown voltage of three samples, pure natural ester oil, natural ester oil with $\mathrm{Fe}_{3} \mathrm{O}_{4}$ nanoparticles and mineral oil. The results showed improvement in the values of BDV for natural ester oil with nanoparticles by $7 \%$. With the addition of nanoparticles, the BDV of natural ester oil increased almost to the mineral oil level. Mohamad et al. [68] studied $\mathrm{Fe}_{3} \mathrm{O}_{4}$ nanoparticles with a size range 15-20 nm suspended in palm oil and modified by oleic acid as a surfactant. The sample of nanofluid with a concentration of $0.01 \mathrm{~g} / \mathrm{L}$ was measured according to the ASTM D6871 standard. The moisture content was lower than $18.0 \mathrm{ppm}$ and $24.9 \mathrm{ppm}$, respectively for pure oil and nanofluid. The two spherical electrodes of $36 \mathrm{~mm}$ in diameter and have a distance of $1 \mathrm{~mm}$ were used. As other researchers, Mohamad et al. also concluded that modification of pure oil by $\mathrm{Fe}_{3} \mathrm{O}_{4}$ nanoparticles can improve the insulating properties of oil. The combination of palm oil and $0.01 \mathrm{~g} / \mathrm{L}$ of iron oxide nanoparticles improved AC BDV 42\%. All results obtained by Mohammad et al. are presented in Figure 2. This also presents a graphical representation of the results obtained by other researchers discussed in the following parts of this review and expressing concentrations as g/L. Rafiq et al. [69] prepared five samples with the following $w / v$ concentrations of $\mathrm{Fe}_{3} \mathrm{O}_{4}$ nanoparticles in oil: $0.05,0.10,0.20,0.40,0.60$ and $0.80 \mathrm{~g} / \mathrm{L}$. The content of moisture for each sample was approximately $15 \mathrm{ppm}$. To achieve better stability of nanofluids, they used oleic acid as a surfactant. AC breakdown voltage for all samples was 
measured according to the IEC 60156 standard. Two spherical brass electrodes with a gap of $2 \mathrm{~mm}$ and a $2 \mathrm{kV} / \mathrm{s}$ voltage rise were employed. The results showed an increase in AC BDV with increasing of the concentration up to $40 \% w / v$, but above this value, it clearly decreases in BDV, as presented in Figure 3. The highest value of BDV was 1.15 times greater than that of pure oil. Rafiq et al. [70] also investigated magnetic $\mathrm{Fe}_{3} \mathrm{O}_{4}$ nanoparticles dispersed in mineral oil with an unspecified concentration. They conducted measurements of BDV values according to the IEC standard and found that nanofluids exhibit 1.14 times higher values of BDV compared to pure mineral oil.

Zou et al. [71] investigated natural ester-based nanofluid with $\mathrm{Fe}_{3} \mathrm{O}_{4}$ nanoparticles and oleic acid as the surfactant. Measurements were performed according to the IEC 156 standard. The average value was calculated, and it was found that $\mathrm{Fe}_{3} \mathrm{O}_{4}$ natural ester nanofluids increase AC BDV by $20 \%$ compared to pure base fluid. Kudelicik et al. [72] investigated the DC breakdown voltage of $\mathrm{Fe}_{3} \mathrm{O}_{4}$ suspended in transformer oil (ITO100). They studied the dependence of breakdown voltage for nanofluids with three different volume concentrations $(0.2,1$ and $2 \mathrm{vol} \%)$ and various distances between electrodes. They used two spherical electrodes $(2.7 \mathrm{~cm}$ in radius) made with cooper, and the distance between them was set with an accuracy of $0.01 \mathrm{~mm}$. The measurements were carried out for distances from $0.1-0.6 \mathrm{~mm}$. The experimental uncertainty was determined as $\pm 10 \%$. For low volume concentrations ( 0.2 and $1 \%$ ) of nanoparticles in transformer oil, they observed an increase in DC BDV; on the other hand, for $2 \mathrm{vol} \%$, a decrease in DC BDV was observed, which was lower than pure transformer oil. Furthermore, the breakdown voltage was increasing with the increasing of distance between electrodes. The details of these investigations are presented in Table 3, which also contains a summary of the results obtained by other researchers, who investigated DC BDV of transformer oils. Segal et al. [73] prepared samples of mineral oil with magnetite nanoparticles $\left(\mathrm{Fe}_{3} \mathrm{O}_{4}\right)$ and with four different levels of moisture content. Each sample aged for 34 weeks at $185^{\circ} \mathrm{C}$. AC BDV measurements were performed according to ASTM D877, and they observed a decrease in AC BDV for both pure oil and nanofluid with increasing moisture content. Additionally, Segal et al. observed also that inclusion of magnetite nanoparticles into oil caused an increase in AC BDV values.

Peppas et al. [74] studied the breakdown voltage of nanofluids containing commercially available $\mathrm{Fe}_{2} \mathrm{O}_{3}$ nanoparticles ( $<50 \mathrm{~nm}$ in diameter) modified by oleic acid and synthesized oleate-coated $\mathrm{Fe}_{2} \mathrm{O}_{3}$ nanoparticles (iron-oleated and oleic acid) and both dispersed in natural ester oil. They prepared six samples for each type of nanofluid with different concentrations from $0.004-0.014 \% w / w$ with a $0.002 \%$ $w / w$ step. The stability of those nanofluids was also investigated, and it turned out that samples containing commercially available nanoparticles had much lower stability (one week to one month) than that synthesized samples (at least 16 months). The maximum value in BDV was very similar in both cases, and it was approximately $78 \mathrm{kV}$ at $0.008 \% w / w$ and $0.012 \% w / w$ for commercially available nanoparticles and synthesized ones, respectively. 


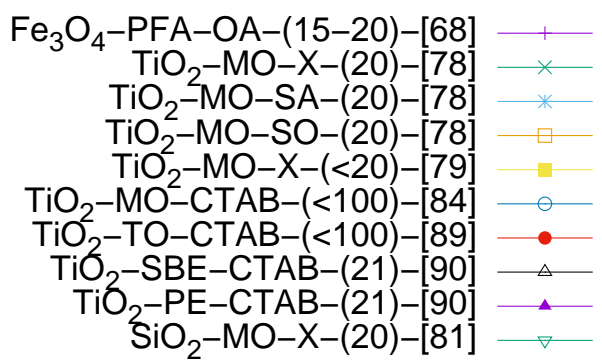

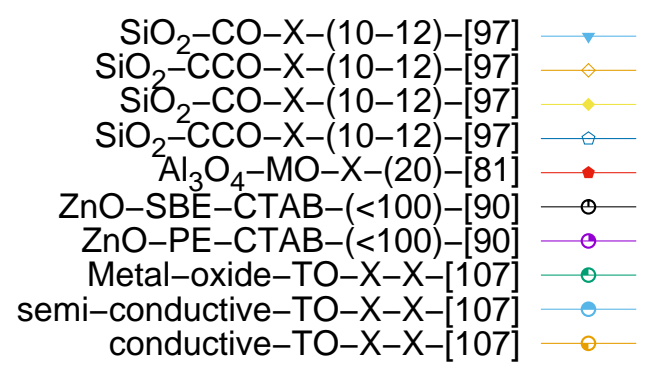
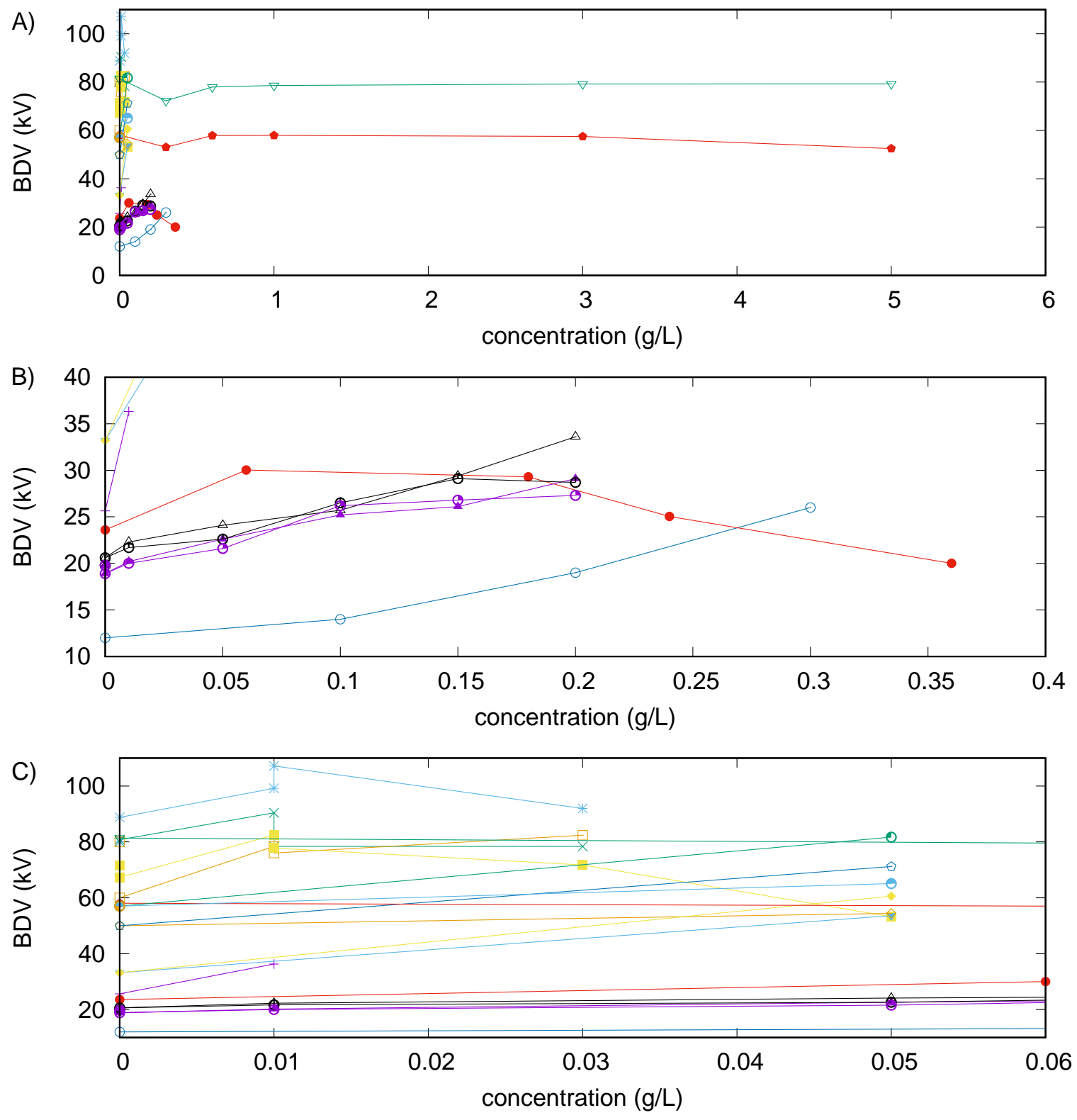

Figure 2. Graphical representation of the values of AC BDV for various types of oil-based nanoparticle nanofluids in concentrations expressed as g/L. (A) Full range of concentration, (B) magnification in concentration range $0-0.4 \mathrm{~g} / \mathrm{L}$ and $(\mathrm{C})$ magnification in concentration range $0-0.06 \mathrm{~g} / \mathrm{L}$. Structure of legend: nanoparticle-base fluid-surfactant-(nanoparticle size)-ref. $\mathrm{X}$, no data available. 

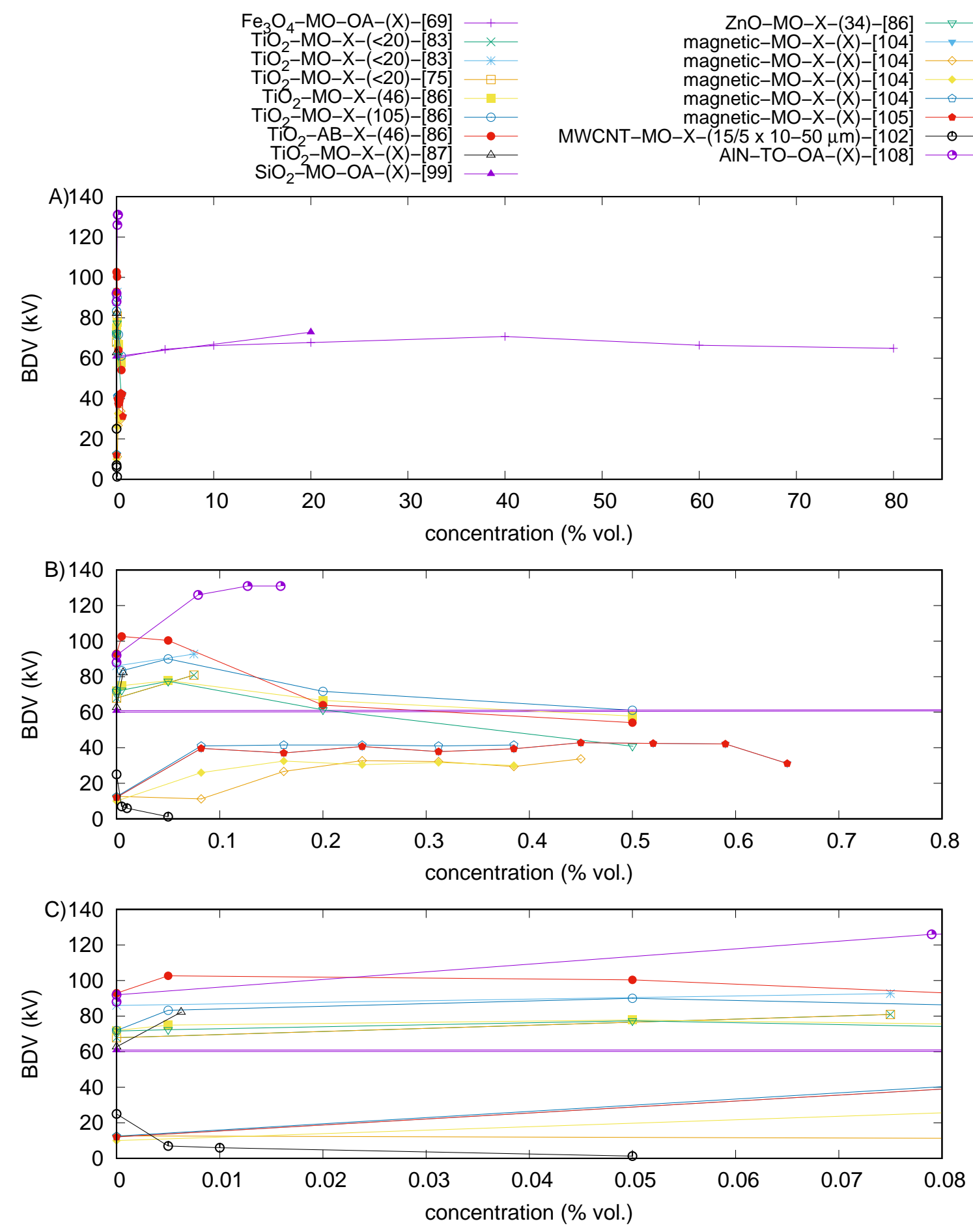

Figure 3. Graphical representation of values of AC BDV for various types of oil-based nanoparticle nanofluids in concentrations expressed by \% of volume. (A) Full range of concentration, (B) magnification in concentration range $0-0.8 \mathrm{vol} \%$ and $(\mathbf{C})$ magnification in concentration range $0-0.08 \mathrm{vol} \%$. Structure of legend: nanoparticle-base fluid-surfactant-(nanoparticle size)-ref. $X$, no data available. 
Table 3. Summary of DC breakdown voltage for various nanofluids.

\begin{tabular}{|c|c|c|c|c|c|c|c|c|c|c|}
\hline NP & BF & Surfactant & Size (nm) & Concentration & $\mathrm{BDV}+(\mathrm{kV})$ & BDV + enh & $\mathrm{BDV}-(\mathrm{kV})$ & BDV - enh & Standard & Ref. \\
\hline \multirow{25}{*}{$\mathrm{Fe}_{3} \mathrm{O}_{4}$} & \multirow{25}{*}{$\mathrm{MO}$} & \multirow{25}{*}{ oleic acid } & \multirow{25}{*}{10.6} & $\mathrm{vol} \%$ & gap $0.2 \mathrm{~mm}$ & & & & \multirow{25}{*}{-} & \multirow{25}{*}[72]{$^{*}$} \\
\hline & & & & 0.0 & 3.40 & 1.00 & - & - & & \\
\hline & & & & 0.2 & 52.68 & 1.05 & - & - & & \\
\hline & & & & 1.0 & 54.41 & 1.08 & - & - & & \\
\hline & & & & 2.0 & 52.38 & 1.04 & - & - & & \\
\hline & & & & \multicolumn{3}{|c|}{ gap $0.3 \mathrm{~mm}$} & & & & \\
\hline & & & & 0.0 & 3.40 & 1.00 & - & - & & \\
\hline & & & & 0.2 & 52.68 & 1.05 & - & - & & \\
\hline & & & & 1.0 & 54.41 & 1.08 & - & - & & \\
\hline & & & & 2.0 & 52.38 & 1.04 & - & - & & \\
\hline & & & & \multicolumn{3}{|c|}{ gap $0.4 \mathrm{~mm}$} & & & & \\
\hline & & & & 0.0 & 3.40 & 1.00 & - & - & & \\
\hline & & & & 0.2 & 52.68 & 1.05 & - & - & & \\
\hline & & & & 1.0 & 54.41 & 1.08 & - & - & & \\
\hline & & & & 2.0 & 52.38 & 1.04 & - & - & & \\
\hline & & & & \multicolumn{3}{|c|}{ gap $0.5 \mathrm{~mm}$} & & & & \\
\hline & & & & 0.0 & 3.40 & 1.00 & - & - & & \\
\hline & & & & 0.2 & 52.68 & 1.05 & - & - & & \\
\hline & & & & 1.0 & 54.41 & 1.08 & - & - & & \\
\hline & & & & 2.0 & 52.38 & 1.04 & - & - & & \\
\hline & & & & \multicolumn{3}{|c|}{ gap $0.6 \mathrm{~mm}$} & & & & \\
\hline & & & & 0.0 & 3.40 & 1.00 & - & - & & \\
\hline & & & & 0.2 & 52.68 & 1.05 & - & - & & \\
\hline & & & & 1.0 & 54.41 & 1.08 & - & - & & \\
\hline & & & & 2.0 & 52.38 & 1.04 & - & - & & \\
\hline \multirow{3}{*}{$\mathrm{TiO}_{2}$} & \multirow{3}{*}{$\mathrm{MO}$} & \multirow{3}{*}{-} & \multirow{3}{*}{$<20$} & vol $\%$ & & & & & \multirow{3}{*}{$\begin{array}{l}\text { ASTM } \\
\text { D3300 }\end{array}$} & \multirow{3}{*}{ [75] } \\
\hline & & & & 0.0 & 49.1 & 1.00 & 66.3 & 1.00 & & \\
\hline & & & & 0.075 & 45.1 & 0.92 & 84.6 & 1.28 & & \\
\hline \multirow{2}{*}{$\mathrm{TiO}_{2}$} & \multirow{2}{*}{$\mathrm{MO}$} & \multirow{2}{*}{-} & \multirow{2}{*}{$<20$} & 0.0 & - & 1.00 & - & - & \multirow{2}{*}{-} & \multirow{2}{*}{ [76] } \\
\hline & & & & $X$ & - & 1.27 & - & - & & \\
\hline
\end{tabular}

* Data read from graph. $\mathrm{X}$, no data available. 


\subsection{Titanium Oxide Nanoparticles}

Another commonly studied material is titanium oxide $\left(\mathrm{TiO}_{2}\right)$ nanoparticles. Du et al. [77] investigated transformer mineral oil-based nanofluids with $\mathrm{TiO}_{2}$ rutile nanoparticles, silicon oil (SO)-treated $\mathrm{TiO}_{2}$ and octadecanoic acid (ODA)-treated $\mathrm{TiO}_{2}$. The average size of the used nanoparticles was less than $20 \mathrm{~nm}$. The concentration of nanoparticles was in the range $0.003-0.05 \mathrm{~g} / \mathrm{mL}$, and moisture content did not exceed $17.5 \mathrm{ppm}$. AC breakdown voltage was measured according to the IEC 60156 standard. They found that optimum concentrations for improvement of AC BDV depended on surface treatment of nanoparticles. Among studied samples, the highest improvement was observed for octadecanoic acid-treated $\mathrm{TiO}_{2}$ suspensions with a concentration of $0.01 \mathrm{~g} / \mathrm{mL}$, and it was $52.9 \%$. For nanofluid containing $\mathrm{TiO}_{2}$ nanoparticles treated by silicon oil, the optimum concentration was also $0.01 \mathrm{~g} / \mathrm{mL}$, but the value of BDV was greater, only $29.6 \%$, than for pure oil. The lowest improvement was reached for untreated $\mathrm{TiO}_{2}$ nanoparticles, and it was $27.5 \%$ for a concentration of $0.006 \mathrm{~g} / \mathrm{mL}$. Lv et al. [78] used spherical $\mathrm{TiO}_{2}$ nanoparticles with various concentration to modify the breakdown voltage properties of transformer oil. Three types of nanofluids with four concentrations $(0.003,0.006,0.010,0.030 \mathrm{~g} / \mathrm{L})$ were prepared. The first contained pure transformer oil with spherical $\mathrm{TiO}_{2}$ nanoparticles. The second and third samples contained modified $\mathrm{TiO}_{2}$ nanoparticles by stearic acid (SA) and silicon oil, respectively. BDV was measured in accordance with the IEC 60156 standard at room temperature. Based on the obtained results, the authors concluded that the best improvement in AC BDV was provided by the addition of stearic acid modified $\mathrm{TiO}_{2}$ nanoparticles with a concentration of $0.010 \mathrm{~g} / \mathrm{L}$; above this content of nanoparticles, AC BDV decreased, but still remained higher than pure oil (up to $0.03 \mathrm{~g} / \mathrm{L}$ ). While silicon oil-modified $\mathrm{TiO}_{2}$ transformer oil-based nanofluid initially showed decreases in AC BDV by $25 \%$, only for a concentration of $0.03 \mathrm{~g} / \mathrm{L}$ did AC BDV increase by $3 \%$. Furthermore, samples with unmodified $\mathrm{TiO}_{2}$ particles are not favorable to enhance the BDV of transformer oil; in turn, in low concentrations, below $0.006 \mathrm{~g} / \mathrm{L}$, a little improvement is visible, and above this concentration of nanoparticles, the BDV of this type of nanofluid decreases. Yue et al. [79] conducted studies of BDV of transformer oil-based nanofluids containing $\mathrm{TiO}_{2}$ nanoparticles with a concentration ranging from $0.003 \mathrm{~g} / \mathrm{L}-0.05 \mathrm{~g} / \mathrm{L}$. Moisture content in all samples was less than $10 \mathrm{ppm}$. Measurements were performed at room temperature and agreed with the IEC 60156 standard. Two brass spherical electrodes with a $2.5 \mathrm{~mm}$ distance between them were employed. Results presented by Yue et al. clearly indicated that using a low concentration of $\mathrm{TiO}_{2}$ nanoparticles increases AC BDV, but above a $0.006 \mathrm{~g} / \mathrm{L}$ concentration of nanoparticles, the BDV value decreases and even reaches a value lower than that of pure oil. Du et al. [80] measured the AC BDV of $\mathrm{TiO}_{2}$ transformer oil-based nanofluids. The dimension of the used nanoparticles was less than $20 \mathrm{~nm}$ in diameter, and surface of the nanoparticles was also modified by surfactant. Measurements proceeded under the ASTM D1816 standard. Results showed that the BDV of transformer oil containing $\mathrm{TiO}_{2}$ nanoparticles increased up to $19.1 \%$. Lv et al. [81] prepared $\mathrm{TiO}_{2}$ transformer oil nanofluids and studied their insulating properties. Nanoparticles with a $20 \mathrm{~nm}$ diameter without any surface modification were used to prepare nanofluids with concentrations in the range of $0-5.0 \mathrm{~g} / \mathrm{L}$. Measurements of BDV were conducted according to the IEC 60156 standard at room temperature. Results showed the dependence of $\mathrm{BDV}$ on $\mathrm{TiO}_{2}$ nanoparticle concentrations. The maximum enhancement was achieved for $0.6 \%$, and it was $13 \%$. In excess of this concentration, the value of BDV decreased even lower than that of pure oil. Mutian et al. [82] used semiconductive $\mathrm{TiO}_{2}$ nanoparticles to modify the breakdown properties of aged mineral oil. Nanoparticles with a size less than $20 \mathrm{~nm}$ in diameter and modified by surfactant were used. Measurements were performed according to ASTM standards (ASTM D1816) at room temperature, using two brass spherical electrodes with a $2 \mathrm{~mm}$-gap and a $2 \mathrm{kV} / \mathrm{s}$ voltage rise. Results showed a 7.8\% enhancement in AC BDV in the presence of $\mathrm{TiO}_{2}$ nanoparticles. Yue-fan et al. [83] studied AC BDV of mineral oil modified by adding $\mathrm{TiO}_{2}$ nanoparticles with a diameter less than $20 \mathrm{~nm}$ and a $0.075 \mathrm{vol} \%$ concentration. The content of moisture in all samples was between 9-10 ppm. They also measured the BDV of nanofluids after aging it at $130{ }^{\circ} \mathrm{C}$ for six days. All samples were dried after the aging process to control water content. Measurements were performed according to 
the IEC 60156 standard with brass spherically-capped electrodes and a $2 \mathrm{~mm}$ distance between them, as well as a $2 \mathrm{kV} / \mathrm{s}$ rise in voltage. Yue-fan et al. observed a 19\% increase in AC BDV for mineral oil containing a $0.075 \%$ volume concentration of nanoparticles. They also noticed that the AC BDV for aged samples was higher compared to fresh samples, but it was caused by the lower content of water after drying. Samples after drying stand out due to the lower increase in AC BDV, which was only $8 \%$. Mineral oil with the addition of $0.075 \% \mathrm{TiO}_{2}$ nanoparticles by volume concentration was investigated by Du et al. [75]. Measurements were conducted in line with the ASTM D1816 standard at room temperature. Results showed a $24 \%$ increase in AC BDV for mineral oil with the addition of nanoparticles. The DC BDV was also measured, and an increase was in negative DC BDV, being $27.6 \%$, wherein for positive DC BDV, a decrease was observed, being $8 \%$. Mansour et al. [84] examined the influence of $\mathrm{TiO}_{2}$ nanoparticles with a diameter less than $100 \mathrm{~nm}$ and cetyltrimethylammonium bromide $(\mathrm{CTAB})$ as the dispersant on the BDV properties of commercially available mineral oil. They prepared six samples with various contents of CTAB $(0.1,0.2,0.3,0.6,1.0,1.5 \mathrm{vol} \%$ fraction) to assess the minimum diameter of agglomeration and a good degree of dispersion. The $0.3 \mathrm{vol} \%$ fraction of CTAB as the dispersant had been chosen using an optical microscope. The three samples with concentrations of $0.1,0.2,0.3 \mathrm{~g} / \mathrm{L}$ and a $0.3 \mathrm{vol} \%$ fraction of CTAB were prepared and investigated according to the ASTM D1816 standard at room temperature with a $2.7 \mathrm{~mm}$ gap and a voltage rise of $500 \mathrm{~V} / \mathrm{s}$. Results indicate an increase in BDV with increasing concentration of nanoparticles in the base fluid, and this increase was $217 \%$. Bakrutheen et al. [85] studied the dielectric breakdown voltage of mineral oil containing two different volume fractions ( $\mathrm{vol} f \mathrm{fr}$ ) of $\mathrm{TiO}_{2}$ nanoparticles $(0.01 \%$ and $0.075 \%$ ). All measurements were conducted in line with the IEC 60156 standard at room temperature with a $2 \mathrm{kV} / \mathrm{s}$ rise in voltage. Measurements conducted immediately after preparation showed a significant decrease in values of BDV for both concentrations. This fact was attributed to moisture absorption from the surrounding during samples preparation. To decrease the moisture content, samples were heated up to $100^{\circ} \mathrm{C}$. After heating the samples up to $100{ }^{\circ} \mathrm{C}$ and cooling them to ambient temperature, BDV measurements were repeated, and a $9 \%$ and $20 \%$ increase in BDV values for a $0.1 \%$ and $0.075 \mathrm{vol} \%$ fraction was observed, respectively. Hanai et al. [86] studied the insulating properties of mineral oil with two different types of $\mathrm{TiO}_{2}$ nanoparticles (anatase and rutile) with various volume concentrations, as well as alkyl benzene $(\mathrm{AB})$ with $\mathrm{TiO}_{2}$-anatase nanoparticles. Samples were prepared with a concentration range from $0-0.5 \mathrm{vol} \%$ using a two-step method, and the water content was less than $15 \mathrm{ppm}$. They used two stainless steel spherical electrodes with a $2.0 \mathrm{~mm}$ gap. Measurements were conducted at room temperature with a $3 \mathrm{kV} / \mathrm{s}$ voltage rise. The maximum enhancement in $\mathrm{BDV}$ was achieved for $\mathrm{TiO}_{2}$-rutile nanoparticles with a volume concentration of $0.05 \%$. In turn, for alkyl benzene containing $\mathrm{TiO}_{2}$-rutile nanoparticles, the maximum enhancement was achieved for a $0.005 \mathrm{vol} \%$ concentration, and it was only $10 \%$. Similar improvement was observed in the case of mineral oil with $\mathrm{TiO}_{2}$-anatase nanoparticles. Additionally, Hanai et al. found that for all cases, the maximum enhancement was observed for a surface area of nanoparticles around $10^{2} \mathrm{~cm}^{2} / \mathrm{mL}$. Zhong et al. [87] studied the influence of $\mathrm{TiO}_{2}$ nanoparticle inclusion with $0.00625 \mathrm{vol} \%$ concentration into natural ester oil FR3 (Cargill Inc., Wayzata, MN, USA). Measurements were conducted according to the ASTM D1816 standard at room temperature with a $2 \mathrm{kV} / \mathrm{s}$ rate of voltage rise. They observed an increase in BDV from $62.71 \mathrm{kV}$ for pure natural ester oil to $82.23 \mathrm{kV}$ for natural ester oil containing $\mathrm{TiO}_{2}$ nanoparticles. Hu et al. [88] studied the time effect on the BDV properties of pure mineral oil and with the addition of $\mathrm{TiO}_{2}$ nanoparticles. They placed samples at a temperature of $130{ }^{\circ} \mathrm{C}$ for 36 days. During this process, every six days, BDV was measured. Each sample before measurements was degassed at less than $1 \mathrm{kPa}$ for two days, which allowed reaching a moisture content below $5 \mathrm{ppm}$. Measurements were conducted in line with the IEC 60156 standard, and the results indicated that BDV decreased with ageing. After 36 days of experiment, the breakdown voltage decreased $58 \%$ and $50 \%$ for pure oil and $\mathrm{TiO}_{2}$-modified oil, respectively. Additionally, it was observed that $\mathrm{BDV}$ for $\mathrm{TiO}_{2}$ nanofluid was always higher than that of pure mineral oil and the end of the test was $40 \%$ higher than the pure oil sample. Rafiq et al. [76] also worked with $\mathrm{TiO}_{2}$ nanoparticles 
suspended in insulating mineral oil. They performed measurements of BDV according to the standard of IEC 60156, using two brass spherically-capped electrodes and a $2 \mathrm{kV} / \mathrm{s}$ voltage rising rate for fresh samples and after the aging process (after heating at $130{ }^{\circ} \mathrm{C}$ for six days). Their results showed a $19 \%$ increase in AC BDV for the fresh sample and a 7\% increase for the sample after ageing. Furthermore, DC BDV was measured, and it was found that the addition of $\mathrm{TiO}_{2}$ nanoparticles to mineral oil caused a $27 \%$ increase in the value of DC BDV. Atiya et al. [89] studied the BDV of transformer oil with dispersed $\mathrm{TiO}_{2}$ nanoparticles with various concentrations modified by CTAB. First, six samples with various contents of surfactant were prepared and examined by an optical microscope, TEM analysis and zeta potential, to choose the best amount of surfactant. Next, four samples with different concentrations of $\mathrm{TiO}_{2}$ nanoparticles were prepared by dispersing $\mathrm{TiO}_{2}$ nanoparticles in a base fluid. Measurements were conducted in line with the ASTM D1816 standard for a ramp voltage up to $500 \mathrm{~V} / \mathrm{s}$ and $1.5 \mathrm{~mm}$ gap sizes. The obtained results showed that the maximum enhancement was achieved for the lowest concentrations of nanoparticles $(0.06 \mathrm{~g} / \mathrm{L})$ in the base fluid, and it was $27 \%$. Saenkhumwong et al. [90] studied the BDV properties of two types of nanofluids based on soybean ester (SBE) and palm ester (PE) in comparison with mineral oil. They prepared five samples with various concentrations (from $0-0.2 \mathrm{~g} / \mathrm{L}$ ) of $\mathrm{TiO}_{2}$ nanoparticles and CTAB as the surfactant for each type of base fluid. Measurements were conducted according to the ASTM D1816 standard and revealed that both soybean and palm ester with dispersed $\mathrm{TiO}_{2}$ nanoparticles showed an increase in the values of BDV with increasing concentration of nanoparticles in natural oils. The maximum enhancement was achieved for concentrations of $0.2 \mathrm{~g} / \mathrm{L}$ for both types of natural oil, and it was $70 \%$ and $47 \%$ for soybean ester and palm ester, respectively. Pugazhendhi et al. [91] conducted studies on the AC BDV properties of mixtures of mineral oil and $\mathrm{TiO}_{2}$ nanoparticles with three different concentrations. They found an increase in BDV for two of three prepared samples; one of them was below BDV values of pure transformer oil. The maximum enhancement was noted for a $0.005 \mathrm{wt} \%$ concentration, and it was $31 \%$. The impact of $\mathrm{TiO}_{2}$ nanoparticles on insulating properties was also investigated by Mansour et al. [92]. They prepared two types of nanofluids containing $\mathrm{TiO}_{2}$ nanoparticles, both in the concentration range between 0.01 and $0.1 \mathrm{~g} / \mathrm{L}$. The first group of samples was prepared without any surfactant and the second with CTAB as the surfactant. Results showed improvement in BDV in both cases, but nanofluids containing surfactants exhibited greater improvement. In the tested concentration range, the maximum increase was observed for $0.07 \mathrm{~g} / \mathrm{L}$ and $0.1 \mathrm{~g} / \mathrm{L}$, and it was $117 \%$ and $126 \%$, respectively, for samples without surfactant and with CTAB.

\subsection{Silicone Oxide Nanoparticles}

Another type of nanoparticle used to modify BDV properties is silicon oxide. Lv et al. [81] studied AC BDV for mineral oil containing $\mathrm{SiO}_{2}$ nanoparticles with various concentrations and without any surfactant. Their study showed that the addition of $\mathrm{SiO}_{2}$ nanoparticles to mineral oil led to a decrease in $\mathrm{BDV}$ in the whole range of tested concentrations $(0-5 \mathrm{~g} / \mathrm{L})$. $\mathrm{SiO}_{2}$ transformer oil-based nanofluids with volume fractions of $0.01 \%$ and $0.075 \%$ were also investigated by Bakrutheen et al. [85]. They found that values of BDV for both nanofluids, measured immediately after preparation, were lower than that of pure oil, and they attributed this to moisture absorption from the air during sample preparation. To remove moisture from the samples, each of them was heated up to $100{ }^{\circ} \mathrm{C}$ and then cooled to ambient temperature. Repeated measurements revealed a $35 \%$ and a $39 \%$ increase in BDV for a $0.01 \%$ and a $0.075 \mathrm{vol} \%$ fraction, respectively. Jin et al. [93,94] studied the breakdown voltage properties of mineral oil with dispersed $\mathrm{SiO}_{2}$ nanoparticles with two different mass fractions and two ranges of humidity. Samples with humidity between 20 and $30 \mathrm{ppm}$ (average $24 \mathrm{ppm}$ ) and 10 and $20 \mathrm{ppm}$ (average $15 \mathrm{ppm}$ ) were measured according to the IEC 60156 standard. Results indicated that the moisture level in samples had a significant impact on the values of BDV. Additionally, it was found that an increase in the concentration of nanoparticles increased BDV by $19 \%$ and $27 \%$ for $0.01 \%$ and $0.02 \%$ mass fractions, respectively, in the case of samples with higher humidity. For samples with a lower content of humidity, the BDV enhancement was also observed, but the nanoparticles' effect was 
less, being $12 \%$ and $17 \%$ for $0.01 \%$ and $0.02 \%$ mass fractions, respectively. Jin et al. [95] also studied the $\mathrm{BDV}$ properties of $\mathrm{SiO}_{2}$ mineral oil-based nanofluids with particles modified by surfactant and two moisture levels. They prepared samples with two types of $\mathrm{SiO}_{2}$ nanoparticles. The first was unmodified particles with a $15 \mathrm{~nm}$ average size, and the second was particles modified by Z6011 with an average size of $25 \mathrm{~nm}$, both with a $0.01 \%$ mass fraction. Results indicated that surface modification of $\mathrm{SiO}_{2}$ nanoparticles reduced the BDV values for both moisture levels. For the sample with a $25 \mathrm{ppm}$ moisture content, it was $37 \%$, but for the sample with a $15 \mathrm{ppm}$ moisture content, it was just $1 \%$. Samples with unmodified nanoparticles showed a $12 \%$ and $20 \%$ increase in BDV for the samples with lower and higher humidity, respectively. Rafiq et al. [96] studied the BDV properties of two oil-based nanofluids with $\mathrm{SiO}_{2}$ nanoparticles synthesized at different temperatures, $80^{\circ} \mathrm{C}$ and $100{ }^{\circ} \mathrm{C}$, for nanoparticles called A and B, respectively. Both samples were prepared with $20 \%$ concentrations of nanoparticles, and measurements were conducted according to the IEC 60156 standard. They found that $\mathrm{BDV}$ was increased by the addition of $\mathrm{SiO}_{2}$ nanoparticles with a $20 \%$ concentration for both types of nanoparticles, and it was $5.7 \%$ and $11.6 \%$ for the A and B nanoparticles, respectively. Karthik and Raymon [97] looked for a biodegradable alternative for insulating mineral oil and tested two types of natural oil with a $0.05 \mathrm{~g} / \mathrm{L}$ concentration of $\mathrm{SiO}_{2}$ nanoparticles. The BDV of corn oil (CO)- and coconut oil (CCO)-based nanofluids were examined according to the IEC 60156 standard. Measurements were conducted at $30{ }^{\circ} \mathrm{C}$ and $60{ }^{\circ} \mathrm{C}$, and the results showed a $61.4 \%$ and an $8.8 \%$ increase in BDV for corn oil- and coconut oil-based nanofluids at $30^{\circ} \mathrm{C}$, respectively. The BDV for these samples at $60{ }^{\circ} \mathrm{C}$ was also increased, and it was $82.5 \%$ and $42.4 \%$ for corn oil- and coconut oil-based nanofluids, respectively. Prasad and Chandrasekar [98] conducted a study on the influence of additions of $\mathrm{SiO}_{2}$ nanoparticles with various mass concentrations on the BDV properties of natural ester oil FR3. They performed measurements according to IEC 60156 with three different gaps between electrodes $(1 \mathrm{~mm}$, $2.5 \mathrm{~mm}, 4 \mathrm{~mm}$ ). Similarly, Kudelcik et al. [72] observed increasing values of DC BDV with increasing distance between electrodes, and Prasad and Chandrasekar observed BDV enhancement for increasing gap between electrodes for all samples. They also found an increase in BDV with increasing mass concentration of $\mathrm{SiO}_{2}$ nanoparticles in the base fluid, and the maximum enhancement was observed for the highest tested concentration $(0.1 \mathrm{wt} \%$ ), being $33.1 \%, 49.7 \%$ and $41.7 \%$ for $1 \mathrm{~mm}, 2.5 \mathrm{~mm}$ and $4 \mathrm{~mm}$ gaps, respectively. Rafiq and Lv [99] studied the impact of a $20 \mathrm{vol} \%$ concentration addition of $\mathrm{SiO}_{2}$ nanoparticles on the BDV properties of mineral oil. Measurements conducted according to the IEC standard showed a 19.7\% enhancement in AC BDV in comparison with the pure oil sample. Dong et al. [100] investigated the insulating properties of mineral oil with surface-modified $\mathrm{SiO}_{2}$ nanoparticles with various volume fractions. They conducted measurements in line with the IEC 60156 standard and found a nonlinear increase in BDV with the increasing content of nanoparticles in the base fluid up to a $0.06 \mathrm{vol} \%$ fraction. Above this concentration, a decrease was observed, but it was still higher than the BDV for pure oil sample. The maximum enhancement observed for a $0.06 \mathrm{vol} \%$ fraction was 33\%. Jianzhuo et al. [101] prepared five samples with various volume fractions of $\mathrm{SiO}_{2}$ nanoparticles dispersed in transformer oil using oleic acid as the surfactant. The measurements were conducted at room temperature $\left(25^{\circ} \mathrm{C}\right)$, and the moisture content was $10 \mathrm{ppm}$. Their results indicated that the increase in nanoparticles content in transformer oil up to a $0.1 \mathrm{vol} \%$ fraction caused an increase in BDV, but above this concentration, a BDV decrease was observed, which was still higher than that in the case of pure base fluid. The most favorable value of BDV in this case was 1.4 higher than that of pure transformer oil.

\subsection{Aluminum Oxide Nanoparticles}

$\mathrm{Al}_{2} \mathrm{O}_{3}$ dispersed in mineral oil with five different concentrations and their BDV properties were studied by $\mathrm{Lv}$ et al. [81]. They used $\mathrm{Al}_{2} \mathrm{O}_{3}$ nanoparticles with a $20 \mathrm{~nm}$ diameter without any surfactant. They performed measurements of BDV according to IEC 60156. Results showed that in the case of $\mathrm{SiO}_{2}$, transformer oil nanofluids decreased in their BDV values in the whole tested range of concentrations. The maximum decrease in BDV was observed for concentrations of $0.3 \mathrm{~g} / \mathrm{L}$ 
and $5.0 \mathrm{~g} / \mathrm{L}$, and it was $20 \%$. Aluminum oxide nanoparticles suspended in transformer oil were also studied by Mansour et al. [92]. They studied the difference between nanofluids containing $\mathrm{Al}_{2} \mathrm{O}_{3}$ nanoparticles suspended in base fluids without any surfactant and with surfactant (sodium dodecyl benzene sulfonate (SDBS)). Four samples for both types of nanofluids were prepared using $\mathrm{Al}_{2} \mathrm{O}_{3}$ nanoparticles with a $50 \mathrm{~nm}$ diameter with concentrations between 0.01 and $0.1 \mathrm{~g} / \mathrm{L}$. Their results clearly indicated that using surfactant improved the insulating properties of transformer nanofluids. In contrast to samples without surfactant, where adding nanoparticles negatively affected BDV in the whole range of tested concentrations, all samples with surfactant exhibited higher values of BDV than that of the pure base fluid. The maximum increase was noted for a concentration of $0.04 \mathrm{~g} / \mathrm{L}$, and it was higher by $28 \%$ than that pure transformer oil.

\subsection{Zinc Oxide Nanoparticles}

Bakrutheen et al. [85] investigated the AC BDV properties of mineral oil with dispersed ZnO nanoparticles with $0.01 \%$ and a $0.075 \mathrm{vol} \%$ fraction and two moisture content levels. Samples were measured immediately after preparation and indicated deterioration in the BDV values, which was attributed to the absorption of water from the surroundings during sample preparation. After removing the excess of moisture by heating samples up to $100{ }^{\circ} \mathrm{C}$ and repeating measurements of BDV, $32 \%$ and $41 \%$ increases were observed for $0.01 \%$ and $0.075 \mathrm{vol} \%$ concentrations, respectively. Hanai et al. [86] also conducted a study on the BDV properties of mineral oil with $\mathrm{ZnO}$ nanoparticles. They used nanoparticles of $34 \mathrm{~nm}$ in diameter dispersed in four various volume concentrations in the range from $0.005-0.05 \%$. The results obtained by Hanai et al. revealed that the addition of $\mathrm{ZnO}$ nanoparticles in some concentrations could improve the insulating properties of mineral oil. For concentrations up to $0.05 \%$, BDV values increased, but above this level of inclusion of nanoparticles, the insulating properties of $\mathrm{ZnO}$ mineral oil-based nanofluid decreased below the level of pure oil, achieving even a $43 \%$ decrease in BDV for a $0.5 \mathrm{vol} \%$ concentration. Saenkhumwong et al. [90] examined the possibilities of using natural ester oils (soybean and palm ester) instead of mineral oils in electrical systems. To improve the insulating properties, they proposed to use $\mathrm{ZnO}$ nanoparticles with a diameter less than $100 \mathrm{~nm}$ and CTAB as the surfactant. They prepared five samples with concentrations ranging from $0.01-0.20 \mathrm{~g} / \mathrm{L}$ for both types of natural oils. Measurements conducted in line with the ASTM D1816 standard revealed that both types of nanofluids were characterized by increasing values of BDV with increasing concentration of nanoparticles. The maximum improvement was achieved for $0.15 \mathrm{~g} / \mathrm{L}$ (soybean ester) and $0.20 \mathrm{~g} / \mathrm{L}$ (palm ester), and it was $47 \%$ and $38 \%$, respectively.

\subsection{Carbon-Based Nanoparticles}

Jin et al. [93] prepared nano-suspensions of mineral oil and fullerene nanoparticles with two different mass fractions in order to investigate their AC BDV properties in comparison with pure mineral oil. The size was specified by the dynamic light scattering (DLS) technique, and it was approximately $70 \mathrm{~nm}$. Samples with $0.05 \%$ and $0.1 \%$ mass fractions and a humidity level of $24 \mathrm{ppm}$ were studied according to the IEC 60156 standard. The study showed the favorable effect of nanoparticles addition on the BDV properties for both concentrations. The highest improvement was noticed for $0.1 \%$, and it was $34 \%$, while the enhancement for $0.05 \%$ was $20 \%$. Fontes et al. [102] prepared nanofluids with multi-wall carbon nanotubes (MWCNT) and nanodiamonds dispersed in mineral oil. They used MWCNT with the following dimensions: 15, $5 \mathrm{~nm}$ and 10-50 $\mu \mathrm{m}$ for the outer diameter, inner diameter and length, respectively, to prepare samples with three volume concentrations: $0.005,0.01$ and $0.05 \%$. The same concentrations were prepared using spherical diamond nanoparticles with a $6 \mathrm{~nm}$ diameter. The BDV of all samples were measured according to the ASTM D1816 standard. The results obtained by Fontes et al. clearly showed a huge decrease in values of the BDV properties for both types of nanofluids. The maximum degradation of BDV was observed for the MWCNT transformer oil nanofluid with the highest volume concentration $(0.05 \%)$, and it was $95 \%$, while for the nanodiamond transformer oil nanofluid, it was $76 \%$. 


\subsection{Other Nanoparticles}

Jian et al. [103] examined the AC BDV for mineral oil modified by three different concentrations of semiconductive nanoparticles. Nanoparticles with diameters less than $20 \mathrm{~nm}$ were used to prepare samples with low, medium and high concentrations. Moisture content in samples did not exceed $100 \mathrm{ppm}$. The properties of all samples were measured according to the IEC 60156 standard, and the results show that the best improvement in BDV values was obtained for a medium concentration of semiconductive nanoparticles, being $16 \%$. Lee et al. [104,105] studied the BDV properties of magnetic mineral oil-based nanofluids with various concentrations, different gap sizes and under the influence of a magnetic field [104]. They prepared samples with a volume concentration in the range of $0.08-0.39 \%$, and the BDV was measured according to the IEC 60156 standard. EFH-1 ferrofluid was used as a modifier of the insulating properties of the mineral oil. They found that an increase in the gap distance between electrodes decreased BDV, which was opposite the results presented by Prasad et al. [98]. Furthermore, the effect of the external magnetic field $(250 \mathrm{mT})$ was observed. A summary of Lee et al.'s measurements is presented in Table 4. Lee et al. [106] also studied a mixture of EFH-1 ferrofluid and transformer oil with volume concentrations starting form $0.08-0.65 \%$ using the measuring stand presented in Figure 4. They conducted measurements according to the IEC 60156 standard with a $1.5 \mathrm{~mm}$ gap and a $1.0 \mathrm{kV} / \mathrm{s}$ voltage rise. Results showed approximately 3.3 times higher values of BDV in comparison to pure transformer oil for volume concentrations up to $0.6 \%$.

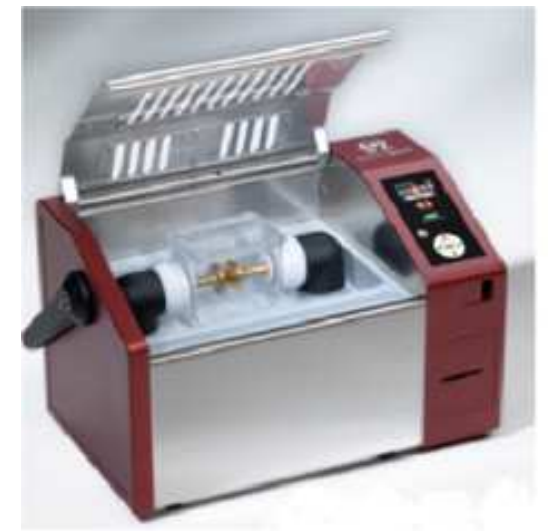

(a) BA75

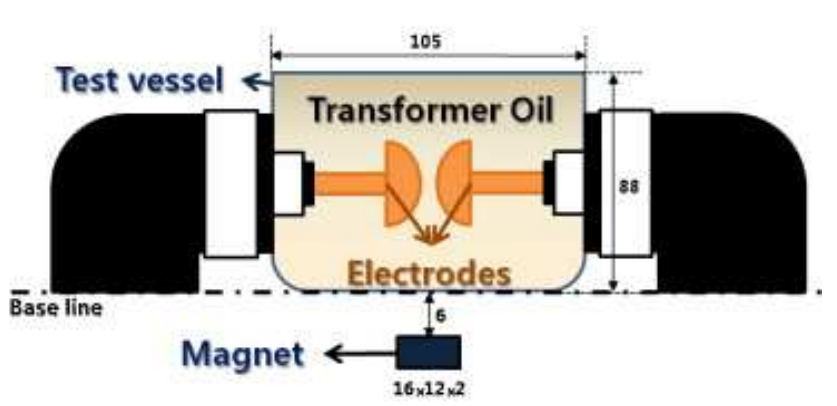

(b) Schematic of main components of BA75

Figure 4. Device for BDV measurements. Reproduced with permission from [106].

For higher concentrations, a visible decrease in the value of BDV is noticed. $\mathrm{ZrO}_{2}$ nanoparticles with a diameter less than $50 \mathrm{~nm}$, dispersed with various mass concentrations in the transformer oil and their AC BDV values were studied by Pugazhendhi et al. [91]. Their results showed the maximum increase for a $0.01 \mathrm{wt} \%$ concentration of $\mathrm{ZrO}_{2}$ nanoparticles, and it was $23 \%$. Above a $0.01 \mathrm{wt} \%$ concentration was observed a decrease in the BDV value from $75.24 \mathrm{kV}$ to $66.13 \mathrm{kV}$. Lv et al. [107] performed studies of the BDV properties of insulating, semiconducting and conducting nanoparticles dispersed in transformer oil with a $0.05-\mathrm{g} / \mathrm{L}$ concentration. They found improvement for all samples, and the highest was for insulating nanoparticles (43\%). The enhancement for other samples was $14 \%$ and $23 \%$ for semiconducting and conducting nanoparticles, respectively. Liu et al. [108] conducted measurements of the AC BDV of AlN nanoparticles with a $40 \mathrm{~nm}$ diameter, dispersed in mineral oil with various concentrations. They found that AlN mineral oil nanofluids were stable at least six months. The maximum enhancement was observed for $0.127 \mathrm{vol} \%$ and $0.159 \mathrm{vol} \%$, and it was $149 \%$.

The results of all values of AC BDV measurements discussed in this review are summarized in Table 4 and plotted in Figure 5. 


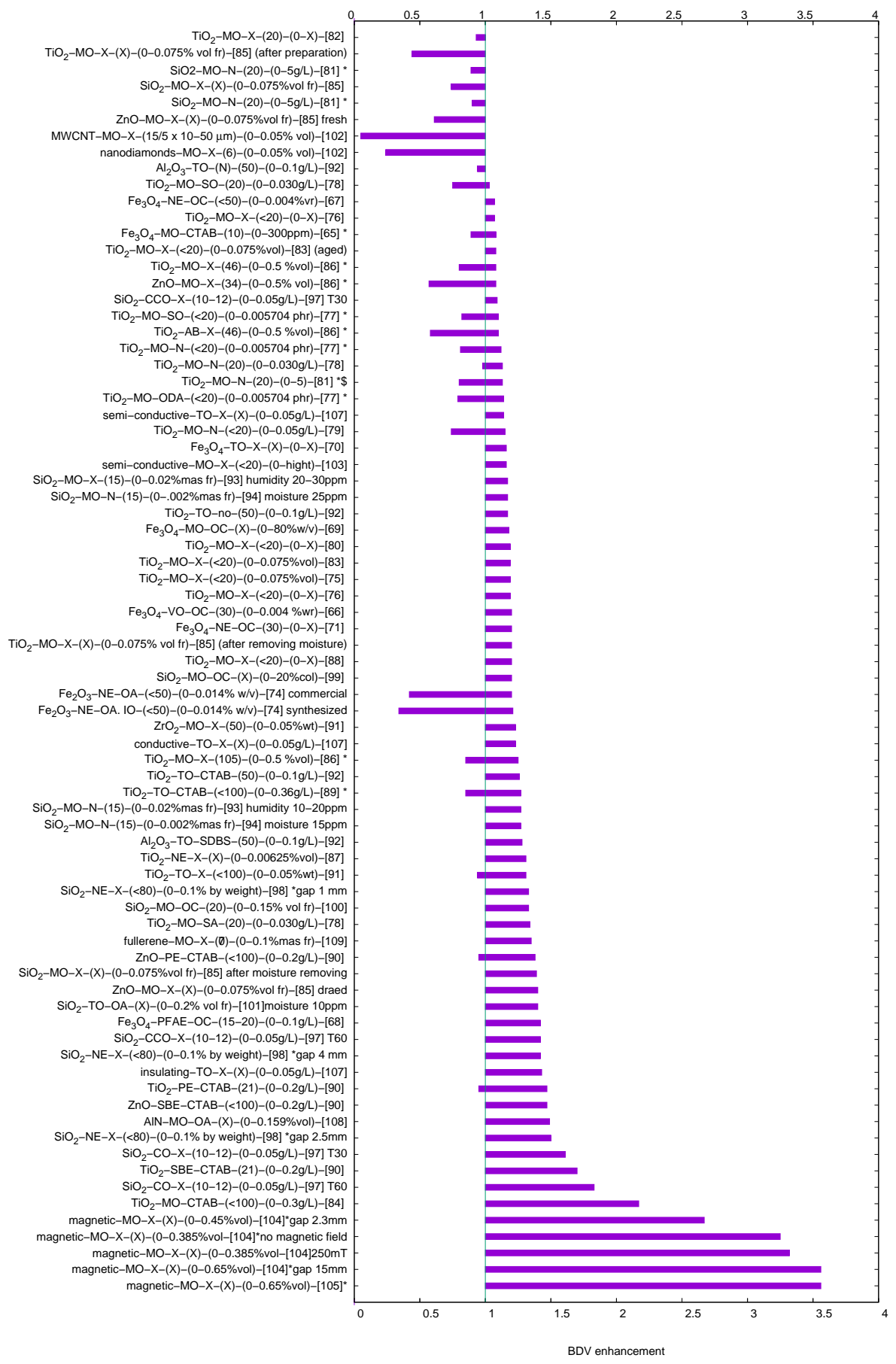

Figure 5. Range of enhancement in AC BDV values of nanoparticle oil-based nanofluids. Structure of legend: nanoparticle-base fluid-surfactant-(nanoparticle size)-(concentration range)-ref. $X$, no data available; N, no surfactant; Y, with surfactant, but unspecified; ${ }^{*}$, data read from graph. 
Table 4. Summary of the AC breakdown voltage for various nanofluids.

\begin{tabular}{|c|c|c|c|c|c|c|c|c|c|}
\hline NP & BF & Surfactant & Size (nm) & Concentrations & BDV & BDV enh & Comments & Standard & Ref. \\
\hline $\mathrm{Fe}_{3} \mathrm{O}_{4}$ & $\mathrm{MO}$ & $\begin{array}{c}\text { СТAB } \\
(0.15 \mathrm{~g})\end{array}$ & 10 & $\begin{array}{c}0 \mathrm{ppm} \\
50 \mathrm{ppm} \\
100 \mathrm{ppm} \\
150 \mathrm{ppm} \\
200 \mathrm{ppm} \\
250 \mathrm{ppm} \\
300 \mathrm{ppm}\end{array}$ & $\begin{array}{l}50.24 \\
52.68 \\
54.41 \\
52.38 \\
53.11 \\
49.09 \\
44.88\end{array}$ & $\begin{array}{l}1.00 \\
1.05 \\
1.08 \\
1.04 \\
1.06 \\
0.98 \\
0.89\end{array}$ & & IEC 60156 & {$[65]$ * } \\
\hline $\mathrm{Fe}_{3} \mathrm{O}_{4}$ & $\mathrm{VO}$ & OA & 30 & $\begin{array}{l}0.000 \% \text { wr } \\
0.004 \% \text { wr }\end{array}$ & $\begin{array}{l}49.90 \\
59.80\end{array}$ & $\begin{array}{l}1.00 \\
1.20\end{array}$ & & IEC 156 & {$[66]$} \\
\hline $\mathrm{Fe}_{3} \mathrm{O}_{4}$ & $\mathrm{NE}$ & OA & $<50$ & $\begin{array}{c}0.000 \% \mathrm{vr} \\
0.004 \% \mathrm{vr} \\
\mathrm{MO}\end{array}$ & $\begin{array}{l}65.40 \\
69.70 \\
70.30\end{array}$ & $\begin{array}{l}1.00 \\
1.07 \\
1.07\end{array}$ & & IEC 156 & [67] \\
\hline $\mathrm{Fe}_{3} \mathrm{O}_{4}$ & PFA & OA & $15-20$ & $\begin{array}{l}0.00 \mathrm{~g} / \mathrm{L} \\
0.01 \mathrm{~g} / \mathrm{L}\end{array}$ & $\begin{array}{l}25.64 \\
36.31\end{array}$ & $\begin{array}{l}1.00 \\
1.42\end{array}$ & & ASTM D6871 & {$[68]$} \\
\hline $\mathrm{Fe}_{3} \mathrm{O}_{4}$ & $\mathrm{MO}$ & OA & - & $\begin{array}{l}0.00 \mathrm{~g} / \mathrm{L} \\
0.05 \mathrm{~g} / \mathrm{L} \\
0.10 \mathrm{~g} / \mathrm{L} \\
0.15 \mathrm{~g} / \mathrm{L} \\
0.20 \mathrm{~g} / \mathrm{L} \\
0.40 \mathrm{~g} / \mathrm{L} \\
0.60 \mathrm{~g} / \mathrm{L} \\
0.80 \mathrm{~g} / \mathrm{L}\end{array}$ & $\begin{array}{l}60.05 \\
64.37 \\
66.26 \\
67.71 \\
70.75 \\
66.42 \\
64.87 \\
60.05\end{array}$ & $\begin{array}{l}1.00 \\
1.07 \\
1.09 \\
1.13 \\
1.18 \\
1.11 \\
1.08 \\
1.00\end{array}$ & & IEC 60156 & [69] \\
\hline $\mathrm{Fe}_{3} \mathrm{O}_{4}$ & TO & - & - & $\begin{array}{c}0.00 \\
X\end{array}$ & $\begin{array}{l}61.04 \\
70.60\end{array}$ & $\begin{array}{l}1.00 \\
1.16\end{array}$ & & IEC 60156 & {$[70]$} \\
\hline $\mathrm{Fe}_{3} \mathrm{O}_{4}$ & $\mathrm{NE}$ & $\mathrm{OA}(0.75 \mathrm{~g})$ & 30 & $\begin{array}{c}0.00 \\
X\end{array}$ & $\begin{array}{l}49.90 \\
59.80\end{array}$ & $\begin{array}{l}1.00 \\
1.20\end{array}$ & & IEC 60156 & {$[71]$} \\
\hline
\end{tabular}


Table 4. Cont.

\begin{tabular}{|c|c|c|c|c|c|c|c|c|c|}
\hline NP & BF & Surfactant & Size (nm) & Concentrations & BDV & BDV enh & Comments & Standard & Ref. \\
\hline \multirow{7}{*}{$\mathrm{Fe}_{2} \mathrm{O}_{3}$} & \multirow{7}{*}{$\mathrm{NE}$} & \multirow{7}{*}{$\mathrm{OA}$} & \multirow{7}{*}{$<50$} & $0.00 \% w / v$ & 64.50 & 1.00 & \multirow{7}{*}{ commercial } & & \multirow{7}{*}{ [74] } \\
\hline & & & & $0.004 \% w / v$ & 70.00 & 1.09 & & & \\
\hline & & & & $0.006 \% w / v$ & 73.00 & 1.13 & & & \\
\hline & & & & $0.008 \% w / v$ & 77.70 & 1.20 & & & \\
\hline & & & & $0.010 \% w / v$ & 59.00 & 0.91 & & & \\
\hline & & & & $0.012 \% w / v$ & 51.00 & 0.79 & & & \\
\hline & & & & $0.014 \% w / v$ & 27.00 & 0.42 & & & \\
\hline \multirow{7}{*}{$\mathrm{Fe}_{2} \mathrm{O}_{3}$} & \multirow{7}{*}{$\mathrm{NE}$} & \multirow{7}{*}{ OA } & \multirow{7}{*}{$<50$} & $0.00 \% w / v$ & 64.50 & 1.00 & \multirow{7}{*}{ synthesized } & & \multirow{7}{*}{ [74] } \\
\hline & & & & $0.004 \% w / v$ & 54.00 & 0.84 & & & \\
\hline & & & & $0.006 \% w / v$ & 55.00 & 0.85 & & & \\
\hline & & & & $0.008 \% w / v$ & 60.00 & 0.93 & & & \\
\hline & & & & $0.010 \% w / v$ & 66.00 & 1.02 & & & \\
\hline & & & & $0.012 \% w / v$ & 77.80 & 1.21 & & & \\
\hline & & & & $0.014 \% w / v$ & 22.00 & 0.34 & & & \\
\hline \multirow{18}{*}{$\mathrm{TiO}_{2}-\mathrm{r}$} & \multirow{18}{*}{$\mathrm{MO}$} & \multirow{6}{*}{-} & & $0.000000 \mathrm{phr}$ & 70.60 & 1.00 & \multirow{6}{*}{$\begin{array}{c}\text { moisture } \\
\text { 9.18-10.21 ppm; } \\
\text { phr-parts per } \\
\text { hundred resin }\end{array}$} & \multirow{18}{*}{ IEC 60156} & \multirow{18}{*}[77]{ * } \\
\hline & & & & $0.000393 \mathrm{phr}$ & 69.55 & 0.99 & & & \\
\hline & & & & $0.000701 \mathrm{phr}$ & 79.30 & 1.12 & & & \\
\hline & & & & $0.001095 \mathrm{phr}$ & 68.31 & 0.97 & & & \\
\hline & & & & $0.003401 \mathrm{phr}$ & 66.95 & 0.95 & & & \\
\hline & & & & $0.005704 \mathrm{phr}$ & 57.14 & 0.81 & & & \\
\hline & & & & $0.000000 \mathrm{phr}$ & 66.60 & 0.94 & & & \\
\hline & & & & $0.000393 \mathrm{phr}$ & 58.23 & 0.82 & & & \\
\hline & & & & $0.000701 \mathrm{phr}$ & 63.27 & 0.90 & moisture & & \\
\hline & & $\mathrm{SO}$ & $<20$ & $0.001095 \mathrm{phr}$ & 77.70 & 1.09 & 9.49-11.62 ppm & & \\
\hline & & & & $0.003401 \mathrm{phr}$ & 74.99 & 1.06 & & & \\
\hline & & & & $0005704 \mathrm{phr}$ & 64.36 & 0.91 & & & \\
\hline & & \multirow{6}{*}{ ODA } & & $0.000000 \mathrm{phr}$ & 60.30 & 0.85 & \multirow{6}{*}{$\begin{array}{c}\text { moisture } \\
12.40-14.05 \text { ppm }\end{array}$} & & \\
\hline & & & & $0.000393 \mathrm{phr}$ & 67.60 & 0.96 & & & \\
\hline & & & & $0.000701 \mathrm{phr}$ & 72.44 & 1.03 & & & \\
\hline & & & & $0.001095 \mathrm{phr}$ & 80.50 & 1.14 & & & \\
\hline & & & & $0.003401 \mathrm{phr}$ & 70.39 & 1.00 & & & \\
\hline & & & & $0.005704 \mathrm{phr}$ & 56.05 & 0.79 & & & \\
\hline
\end{tabular}


Table 4. Cont

\begin{tabular}{|c|c|c|c|c|c|c|c|c|c|}
\hline NP & BF & Surfactant & Size $(\mathrm{nm})$ & Concentrations & BDV & BDV enh & Comments & Standard & Ref. \\
\hline \multirow{15}{*}{$\mathrm{TiO}_{2}-\mathrm{r}$} & \multirow{15}{*}{$\mathrm{MO}$} & \multirow{5}{*}{-} & \multirow{15}{*}{20} & $0.000 \mathrm{~g} / \mathrm{L}$ & 80.00 & 1.00 & & \multirow{15}{*}{ IEC 60156} & \multirow{15}{*}{ [78] } \\
\hline & & & & $0.003 \mathrm{~g} / \mathrm{L}$ & 80.80 & 1.01 & & & \\
\hline & & & & $0.006 \mathrm{~g} / \mathrm{L}$ & 90.40 & 1.13 & & & \\
\hline & & & & $0.010 \mathrm{~g} / \mathrm{L}$ & 78.40 & 0.98 & & & \\
\hline & & & & $0.030 \mathrm{~g} / \mathrm{L}$ & 78.40 & 0.98 & & & \\
\hline & & & & $0.000 \mathrm{~g} / \mathrm{L}$ & 80.00 & 1.00 & & & \\
\hline & & & & $0.003 \mathrm{~g} / \mathrm{L}$ & 88.80 & 1.11 & & & \\
\hline & & SA & & $0.006 \mathrm{~g} / \mathrm{L}$ & 99.20 & 1.24 & & & \\
\hline & & SA & & $0.010 \mathrm{~g} / \mathrm{L}$ & 107.20 & 1.34 & & & \\
\hline & & & & $0.030 \mathrm{~g} / \mathrm{L}$ & 92.00 & 1.15 & & & \\
\hline & & \multirow{5}{*}{ SO } & & $0.000 \mathrm{~g} / \mathrm{L}$ & 80.00 & 1.00 & & & \\
\hline & & & & $0.003 \mathrm{~g} / \mathrm{L}$ & 60.00 & 0.75 & & & \\
\hline & & & & $0.006 \mathrm{~g} / \mathrm{L}$ & 78.40 & 0.98 & & & \\
\hline & & & & $0.010 \mathrm{~g} / \mathrm{L}$ & 76.00 & 0.95 & & & \\
\hline & & & & $0.030 \mathrm{~g} / \mathrm{L}$ & 82.40 & 1.03 & & & \\
\hline \multirow{6}{*}{$\mathrm{TiO}_{2}-\mathrm{r}$} & \multirow{6}{*}{$\mathrm{MO}$} & \multirow{6}{*}{-} & \multirow{6}{*}{$<20$} & $0.000 \mathrm{~g} / \mathrm{L}$ & 71.59 & 1.00 & & \multirow{6}{*}{ - } & \multirow{6}{*}{ [79] } \\
\hline & & & & $0.003 \mathrm{~g} / \mathrm{L}$ & 67.33 & 0.94 & & & \\
\hline & & & & $0.006 \mathrm{~g} / \mathrm{L}$ & 82.48 & 1.15 & & & \\
\hline & & & & $0.010 \mathrm{~g} / \mathrm{L}$ & 77.82 & 1.09 & & & \\
\hline & & & & $0.030 \mathrm{~g} / \mathrm{L}$ & 71.76 & 1.00 & & & \\
\hline & & & & $0.050 \mathrm{~g} / \mathrm{L}$ & 53.25 & 0.74 & & & \\
\hline \multirow{2}{*}{$\mathrm{TiO}_{2}$} & \multirow{2}{*}{$\mathrm{TO}$} & \multirow{2}{*}{ - } & \multirow{2}{*}{$<20$} & 0 & 67.90 & 1.00 & & \multirow{2}{*}{ ASTM D1816 } & \multirow{2}{*}{ [80] } \\
\hline & & & & $x$ & 80.90 & 1.19 & & & \\
\hline \multirow{6}{*}{$\mathrm{TiO}_{2}-\mathrm{r}$} & \multirow{6}{*}{$\mathrm{MO}$} & \multirow{6}{*}{-} & \multirow{6}{*}{20} & 0.0 & 66.11 & 1.00 & \multirow{6}{*}{$\begin{array}{c}\text { No data } \\
\text { about type of } \\
\text { concentration }\end{array}$} & \multirow{6}{*}{ IEC 60156} & \multirow{6}{*}[81]{$^{*}$} \\
\hline & & & & 0.3 & 66.87 & 1.01 & & & \\
\hline & & & & 0.6 & 74.40 & 1.13 & & & \\
\hline & & & & 1.0 & 65.12 & 0.99 & & & \\
\hline & & & & 3.0 & 65.12 & 0.99 & & & \\
\hline & & & & 5.0 & 53.10 & 0.80 & & & \\
\hline
\end{tabular}


Table 4. Cont.

\begin{tabular}{|c|c|c|c|c|c|c|c|c|c|}
\hline NP & BF & Surfactant & Size $(\mathrm{nm})$ & Concentrations & BDV & BDV enh & Comments & Standard & Ref. \\
\hline \multirow{2}{*}{$\mathrm{TiO}_{2}$} & \multirow{2}{*}{$\mathrm{MO}$} & \multirow{2}{*}{ - } & \multirow{2}{*}{20} & 0 & 86.00 & 1.00 & & & \multirow{2}{*}{ [82] } \\
\hline & & & & $x$ & 92.70 & 0.93 & & & \\
\hline \multirow{4}{*}{$\mathrm{TiO}_{2}$} & \multirow{4}{*}{$\mathrm{MO}$} & \multirow{4}{*}{ - } & \multirow{4}{*}{$<20$} & $0.000 \mathrm{vol} \%$ & 67.90 & 1.00 & fresh & \multirow{4}{*}{ IEC 60156} & \multirow{4}{*}{ [83] } \\
\hline & & & & $0.075 \mathrm{vol} \%$ & 80.90 & 1.19 & tresh & & \\
\hline & & & & $0.000 \mathrm{vol} \%$ & 86.02 & 1.00 & & & \\
\hline & & & & $0.075 \mathrm{vol} \%$ & 92.68 & 1.08 & aged & & \\
\hline \multirow{2}{*}{$\mathrm{TiO}_{2}$} & \multirow{2}{*}{$\mathrm{MO}$} & \multirow{2}{*}{-} & \multirow{2}{*}{$<20$} & $0.000 \mathrm{vol} \%$ & 67.9 & 1.00 & & \multirow{2}{*}{ ASTM D1816 } & \multirow{2}{*}{ [75] } \\
\hline & & & & $0.075 \mathrm{vol} \%$ & 80.9 & 1.19 & & & \\
\hline \multirow{4}{*}{$\mathrm{TiO}_{2}$} & \multirow{4}{*}{$\mathrm{MO}$} & \multirow{4}{*}{ CTAB } & \multirow{4}{*}{$<100$} & $0.0 \mathrm{~g} / \mathrm{L}$ & 12 & 1.00 & & \multirow{4}{*}{ ASTM D1816 } & \multirow{4}{*}{ [84] } \\
\hline & & & & $0.1 \mathrm{~g} / \mathrm{L}$ & 14 & 1.17 & & & \\
\hline & & & & $0.2 \mathrm{~g} / \mathrm{L}$ & 19 & 1.58 & & & \\
\hline & & & & $0.3 \mathrm{~g} / \mathrm{L}$ & 26 & 2.17 & & & \\
\hline \multirow{5}{*}{$\mathrm{TiO}_{2}$} & \multirow{5}{*}{$\mathrm{MO}$} & \multirow{5}{*}{-} & \multirow{5}{*}{ - } & $0.000 \mathrm{vol} \%$ fr & 32 & 1.00 & & \multirow{5}{*}{ IEC 60156} & \multirow{5}{*}{ [85] } \\
\hline & & & & $0.010 \mathrm{vol} \% \mathrm{fr}$ & 14 & 0.44 & after & & \\
\hline & & & & $0.075 \mathrm{vol} \% \mathrm{fr}$ & 22 & 0.69 & & & \\
\hline & & & & $0.010 \mathrm{vol} \%$ fr & 35 & 1.09 & after removing & & \\
\hline & & & & $0.075 \mathrm{vol} \% \mathrm{fr}$ & 38.4 & 1.20 & moisture & & \\
\hline \multirow{5}{*}{$\mathrm{TiO}_{2}-\mathrm{a}$} & & & & $0.00 \mathrm{vol} \%$ & 71.91 & 1.00 & & & \\
\hline & & & & $0.005 \mathrm{vol} \%$ & 74.89 & 1.04 & & & \\
\hline & $\mathrm{MO}$ & - & 46 & $0.050 \mathrm{vol} \%$ & 77.80 & 1.08 & & & {$[86]^{*}$} \\
\hline & & & & $0.200 \mathrm{vol} \%$ & 66.66 & 0.93 & & & \\
\hline & & & & $0.500 \mathrm{vol} \%$ & 57.84 & 0.80 & & & \\
\hline & & & & $0.000 \mathrm{vol} \%$ & 71.91 & 1.00 & & & \\
\hline & & & & $0.005 \mathrm{vol} \%$ & 83.29 & 1.16 & & & \\
\hline $\mathrm{TiO}_{2}-\mathrm{r}$ & $\mathrm{MO}$ & - & 105 & 0.05 vol $\%$ & 90.01 & 1.25 & & & {$[86]^{*}$} \\
\hline & & & & $0.2 \mathrm{vol} \%$ & 71.71 & 1.00 & & & \\
\hline & & & & $0.5 \mathrm{vol} \%$ & 61.07 & 0.85 & & & \\
\hline
\end{tabular}


Table 4. Cont.

\begin{tabular}{|c|c|c|c|c|c|c|c|c|c|}
\hline NP & BF & Surfactant & Size (nm) & Concentrations & BDV & BDV enh & Comments & Standard & Ref. \\
\hline \multirow{5}{*}{$\mathrm{TiO}_{2}$-a } & \multirow{5}{*}{$\mathrm{AB}$} & \multirow{5}{*}{-} & \multirow{5}{*}{46} & $0.000 \mathrm{vol} \%$ & 92.88 & 1.00 & & & \multirow{5}{*}[86]{$^{*}$} \\
\hline & & & & $0.005 \mathrm{vol} \%$ & 102.62 & 1.10 & & & \\
\hline & & & & $0.05 \mathrm{vol} \%$ & 100.38 & 1.08 & & & \\
\hline & & & & $0.2 \mathrm{vol} \%$ & 63.95 & 0.69 & & & \\
\hline & & & & $0.5 \mathrm{vol} \%$ & 54.09 & 0.58 & & & \\
\hline \multirow{2}{*}{$\mathrm{TiO}_{2}$} & \multirow{2}{*}{$\mathrm{NE}$} & \multirow{2}{*}{-} & \multirow{2}{*}{ - } & $0.000 \mathrm{vol} \%$ & 62.71 & 1.00 & & \multirow{2}{*}{ ASTM D1816 } & \multirow{2}{*}{ [87] } \\
\hline & & & & $0.00625 \mathrm{vol} \%$ & 82.23 & 1.31 & & & \\
\hline \multirow{15}{*}{$\mathrm{TiO}_{2}$} & \multirow{15}{*}{$\mathrm{MO}$} & \multirow{15}{*}{-} & \multirow{15}{*}{$<20$} & Time (day) & & & \multirow{8}{*}{ pure oil } & \multirow{15}{*}{ IEC 60156} & \multirow{15}{*}[88]{$^{*}$} \\
\hline & & & & 0 & 67.47 & 1.00 & & & \\
\hline & & & & 6 & 60.39 & 0.90 & & & \\
\hline & & & & 12 & 59.10 & 0.88 & & & \\
\hline & & & & 18 & 55.93 & 0.83 & & & \\
\hline & & & & 24 & 40.19 & 0.60 & & & \\
\hline & & & & 30 & 39.20 & 0.58 & & & \\
\hline & & & & 36 & 28.54 & 0.42 & & & \\
\hline & & & & 0 & 80.68 & 1.00 & \multirow{7}{*}{ nanofluid } & & \\
\hline & & & & 6 & 71.08 & 0.88 & & & \\
\hline & & & & 12 & 66.52 & 0.82 & & & \\
\hline & & & & 18 & 64.64 & 0.80 & & & \\
\hline & & & & 24 & 59.40 & 0.74 & & & \\
\hline & & & & 30 & 60.59 & 0.75 & & & \\
\hline & & & & 36 & 40.08 & 0.50 & & & \\
\hline \multirow{4}{*}{$\mathrm{TiO}_{2}$} & \multirow{4}{*}{$\mathrm{MO}$} & \multirow{4}{*}{-} & \multirow{4}{*}{$<20$} & 0 & - & 1.00 & \multirow{2}{*}{ fresh } & \multirow{4}{*}{ IEC 60156} & \multirow{4}{*}{ [76] } \\
\hline & & & & $x$ & - & 1.19 & & & \\
\hline & & & & 0 & - & 1.00 & & & \\
\hline & & & & $x$ & - & 1.07 & after 6 days & & \\
\hline \multirow{5}{*}{$\mathrm{TiO}_{2}$} & \multirow{5}{*}{ oil } & & & $0.00 \mathrm{~g} / \mathrm{L}$ & 23.60 & 1.00 & & & \\
\hline & & & & $0.06 \mathrm{~g} / \mathrm{L}$ & 30.03 & 1.27 & & & \\
\hline & & СТАВ & $<100$ & $0.18 \mathrm{~g} / \mathrm{L}$ & 29.30 & 1.24 & & ASTM D1816 & {$[89]^{*}$} \\
\hline & & & & $0.24 \mathrm{~g} / \mathrm{L}$ & 25.04 & 1.04 & & & \\
\hline & & & & $0.36 \mathrm{~g} / \mathrm{L}$ & 20.00 & 0.85 & & & \\
\hline
\end{tabular}


Table 4. Cont.

\begin{tabular}{|c|c|c|c|c|c|c|c|c|c|}
\hline NP & BF & Surfactant & Size (nm) & Concentrations & BDV & BDV enh & Comments & Standard & Ref. \\
\hline \multirow{13}{*}{$\mathrm{TiO}_{2}$} & $\mathrm{MO}$ & \multirow{13}{*}{$\begin{array}{c}\text { CTAB } \\
(3 \mathrm{~g} / \mathrm{L})\end{array}$} & \multirow{13}{*}{$<100$} & $0.00 \mathrm{~g} / \mathrm{L}$ & 19.80 & 1.00 & & \multirow{13}{*}{ ASTM D1816 } & \multirow{13}{*}[90]{} \\
\hline & \multirow{6}{*}{ SBE } & & & $0.00 \mathrm{~g} / \mathrm{L}$ & 20.60 & 1.04 & & & \\
\hline & & & & $0.01 \mathrm{~g} / \mathrm{L}$ & 22.30 & 1.13 & & & \\
\hline & & & & $0.05 \mathrm{~g} / \mathrm{L}$ & 24.10 & 1.22 & & & \\
\hline & & & & $0.1 \mathrm{~g} / \mathrm{L}$ & 25.70 & 1.30 & & & \\
\hline & & & & $0.15 \mathrm{~g} / \mathrm{L}$ & 29.40 & 1.48 & & & \\
\hline & & & & $0.2 \mathrm{~g} / \mathrm{L}$ & 33.60 & 1.70 & & & \\
\hline & \multirow{6}{*}{ PE } & & & $0.00 \mathrm{~g} / \mathrm{L}$ & 18.90 & 0.95 & & & \\
\hline & & & & $0.01 \mathrm{~g} / \mathrm{L}$ & 20.20 & 1.02 & & & \\
\hline & & & & $0.05 \mathrm{~g} / \mathrm{L}$ & 22.60 & 1.14 & & & \\
\hline & & & & $0.10 \mathrm{~g} / \mathrm{L}$ & 25.20 & 1.27 & & & \\
\hline & & & & $0.15 \mathrm{~g} / \mathrm{L}$ & 26.10 & 1.32 & & & \\
\hline & & & & $0.20 \mathrm{~g} / \mathrm{L}$ & 29.10 & 1.47 & & & \\
\hline \multirow{4}{*}{$\mathrm{TiO}_{2}$} & \multirow{4}{*}{$\mathrm{TO}$} & \multirow{4}{*}{-} & \multirow{4}{*}{$<100$} & $0.000 \mathrm{wt} \%$ & 61.20 & 1.00 & \multirow{14}{*}{ moisture 25.7 ppm } & \multirow{4}{*}{ IS 6792:1972 } & \multirow{4}{*}{ [91] } \\
\hline & & & & $0.005 w t \%$ & 80.36 & 1.31 & & & \\
\hline & & & & $0.010 w t \%$ & 75.15 & 1.23 & & & \\
\hline & & & & $0.050 \mathrm{wt} \%$ & 57.60 & 0.94 & & & \\
\hline \multirow{10}{*}{$\mathrm{TiO}_{2}$} & \multirow{10}{*}{$\mathrm{TO}$} & \multirow{10}{*}{ СТАВ } & \multirow{10}{*}{50} & $0.00 \mathrm{~g} / \mathrm{L}$ & 69.00 & 1.00 & & & \multirow{10}{*}{ [92] } \\
\hline & & & & $0.01 \mathrm{~g} / \mathrm{L}$ & 71.00 & 1.03 & & & \\
\hline & & & & $0.04 \mathrm{~g} / \mathrm{L}$ & 77.00 & 1.12 & & & \\
\hline & & & & $0.07 \mathrm{~g} / \mathrm{L}$ & 81.00 & 1.17 & & & \\
\hline & & & & $0.10 \mathrm{~g} / \mathrm{L}$ & 78.00 & 1.13 & & & \\
\hline & & & & $0.00 \mathrm{~g} / \mathrm{L}$ & 69.00 & 1.00 & & & \\
\hline & & & & $0.01 \mathrm{~g} / \mathrm{L}$ & 82.00 & 1.19 & & & \\
\hline & & & & $0.04 \mathrm{~g} / \mathrm{L}$ & 78.00 & 1.13 & & & \\
\hline & & & & $0.07 \mathrm{~g} / \mathrm{L}$ & 80.00 & 1.16 & & & \\
\hline & & & & $0.10 \mathrm{~g} / \mathrm{L}$ & 87.00 & 1.26 & & & \\
\hline \multirow{6}{*}{$\mathrm{SiO}_{2}$} & \multirow{6}{*}{ MO } & \multirow{6}{*}{-} & \multirow{6}{*}{20} & $0.0 \mathrm{~g} / \mathrm{L}$ & 81.40 & 1.00 & & & \multirow{6}{*}{ [81] } \\
\hline & & & & $0.3 \mathrm{~g} / \mathrm{L}$ & 72.27 & 0.89 & & & \\
\hline & & & & $0.6 \mathrm{~g} / \mathrm{L}$ & 77.97 & 0.96 & & & \\
\hline & & & & $1.0 \mathrm{~g} / \mathrm{L}$ & 78.58 & 0.97 & & & \\
\hline & & & & $3.0 \mathrm{~g} / \mathrm{L}$ & 79.19 & 0.97 & & & \\
\hline & & & & $5.0 \mathrm{~g} / \mathrm{L}$ & 79.27 & 0.97 & & & \\
\hline
\end{tabular}


Table 4. Cont.

\begin{tabular}{|c|c|c|c|c|c|c|c|c|c|}
\hline NP & BF & Surfactant & Size $(\mathrm{nm})$ & Concentrations & BDV & BDV enh & Comments & Standard & Ref. \\
\hline \multirow{5}{*}{$\mathrm{SiO}_{2}$} & \multirow{5}{*}{$\mathrm{MO}$} & \multirow{5}{*}{-} & \multirow{5}{*}{-} & $0.00 \mathrm{vol} \% \mathrm{fr}$ & 32.00 & 1.00 & \multirow{3}{*}{ after preparation } & \multirow{5}{*}{ IEC 60156} & \multirow{5}{*}{ [85] } \\
\hline & & & & $0.01 \mathrm{vol} \% \mathrm{fr}$ & 23.80 & 0.74 & & & \\
\hline & & & & $0.075 \mathrm{vol} \% \mathrm{fr}$ & 28.80 & 0.90 & & & \\
\hline & & & & $0.01 \mathrm{vol} \% \mathrm{fr}$ & 43.20 & 1.35 & \multirow{2}{*}{$\begin{array}{l}\text { after removing } \\
\text { moisture }\end{array}$} & & \\
\hline & & & & $0.075 \mathrm{vol} \% \mathrm{fr}$ & 44.60 & 1.39 & & & \\
\hline \multirow{6}{*}{$\mathrm{SiO}_{2}$} & \multirow{6}{*}{$\mathrm{MO}$} & \multirow{6}{*}{-} & \multirow{6}{*}{15} & $0.00 \%$ mas fr & 51.3 & 1.00 & \multirow{3}{*}{$\begin{array}{l}\text { humidity } \\
10-20 \text { ppm }\end{array}$} & \multirow{6}{*}{ IEC 60156} & \multirow{6}{*}{ [93] } \\
\hline & & & & $0.01 \%$ masfr & 61.2 & 1.19 & & & \\
\hline & & & & $0.02 \%$ mas fr & 65.1 & 1.27 & & & \\
\hline & & & & $0.00 \%$ mas fr & 76.00 & 1.00 & \multirow{3}{*}{$\begin{array}{l}\text { humidity } \\
20-30 \text { ppm }\end{array}$} & & \\
\hline & & & & $0.01 \%$ mas fr & 85.4 & 1.12 & & & \\
\hline & & & & $0.02 \%$ mas fr & 89.2 & 1.17 & & & \\
\hline \multirow{6}{*}{$\mathrm{SiO}_{2}$} & \multirow{6}{*}{$\mathrm{MO}$} & \multirow{6}{*}{-} & \multirow{6}{*}{15} & $0.00 \%$ mas fr & 51 & 100 & \multirow{3}{*}{$\begin{array}{l}\text { moisture } \\
15 \text { ppm }\end{array}$} & \multirow{6}{*}{ IEC 60156} & \multirow{6}{*}[94]{} \\
\hline & & & & $001 \%$ mas fr & 61 & 120 & & & \\
\hline & & & & $002 \%$ mas fr & 65 & 127 & & & \\
\hline & & & & $0.00 \%$ mas fr & 76 & 1.00 & \multirow{3}{*}{$\begin{array}{l}\text { moisture } \\
25 \text { ppm }\end{array}$} & & \\
\hline & & & & $0.01 \%$ mas fr & 85 & 1.12 & & & \\
\hline & & & & $0.02 \%$ mas fr & 89 & 1.17 & & & \\
\hline \multirow{6}{*}{$\mathrm{SiO}_{2}$} & \multirow{6}{*}{$\mathrm{MO}$} & - & - & $0.00 \%$ mass $\mathrm{fr}$ & 76 & 1.00 & & \multirow{6}{*}{ IEC 60156} & \multirow{6}{*}{ [95] } \\
\hline & & - & 15 & $0.01 \%$ mass $\mathrm{fr}$ & 85 & 1.12 & humidity 15 ppm & & \\
\hline & & Z6011 & 25 & $0.01 \%$ mass $\mathrm{fr}$ & 75 & 0.99 & & & \\
\hline & & & & $0.00 \%$ mass fr & 51 & 1.00 & \multirow{3}{*}{ humidity 25 ppm } & & \\
\hline & & - & 15 & $0.01 \%$ mass $\mathrm{fr}$ & 61 & 1.20 & & & \\
\hline & & Z6011 & 25 & $0.01 \%$ mass fr & 32 & 0.63 & & & \\
\hline \multirow{3}{*}{$\mathrm{SiO}_{2}$} & \multirow{3}{*}{$\mathrm{MO}$} & & & 0 & 50.9 & 1.00 & & & \\
\hline & & - & $\mathrm{A}$ & 20 & 53.8 & 1.04 & & IEC 60156 & [96] \\
\hline & & & $\mathrm{B}$ & 20 & 56.8 & 1.12 & & & \\
\hline
\end{tabular}


Table 4. Cont.

\begin{tabular}{|c|c|c|c|c|c|c|c|c|c|}
\hline NP & BF & Surfactant & Size $(\mathrm{nm})$ & Concentrations & BDV & BDV enh & Comments & Standard & Ref. \\
\hline \multirow{8}{*}{$\mathrm{SiO}_{2}$} & \multirow{2}{*}{$\mathrm{CO}$} & & & $0.00 \mathrm{~g} / \mathrm{L}$ & 33.2 & 1.00 & \multirow{4}{*}{$\mathrm{T}=30^{\circ} \mathrm{C}$} & \multirow{8}{*}{ IEC 60156} & \multirow{8}{*}{ [97] } \\
\hline & & & & $0.05 \mathrm{~g} / \mathrm{L}$ & 53.6 & 1.61 & & & \\
\hline & CCO & & & $0.00 \mathrm{~g} / \mathrm{L}$ & 50 & 1.00 & & & \\
\hline & $c c 0$ & - & $10-12$ & $0.05 \mathrm{~g} / \mathrm{L}$ & 54.4 & 1.09 & & & \\
\hline & CO & & & $0.00 \mathrm{~g} / \mathrm{L}$ & 332 & 1.00 & \multirow{4}{*}{$\mathrm{T}=60^{\circ} \mathrm{C}$} & & \\
\hline & co & & & $0.05 \mathrm{~g} / \mathrm{L}$ & 60.6 & 1.83 & & & \\
\hline & \multirow{2}{*}{$\mathrm{CCO}$} & & & $0.00 \mathrm{~g} / \mathrm{L}$ & 50 & 100 & & & \\
\hline & & & & $0.05 \mathrm{~g} / \mathrm{L}$ & 712 & 142 & & & \\
\hline \multirow{12}{*}{$\mathrm{SiO}_{2}$} & \multirow{12}{*}{ NE } & \multirow{12}{*}{-} & \multirow{12}{*}{$<80$} & $0.00 w \mathrm{t} \%$ & 30.03 & 1.00 & \multirow{4}{*}{ gap 1 mm } & \multirow{12}{*}{ IEC 60156} & \multirow{12}{*}[98]{$^{*}$} \\
\hline & & & & $0.01 w t \%$ & 34.92 & 1.16 & & & \\
\hline & & & & 0.05 wt $\%$ & 37.96 & 1.26 & & & \\
\hline & & & & $0.10 w \mathrm{t} \%$ & 39.97 & 1.33 & & & \\
\hline & & & & $0.00 \mathrm{wt} \%$ & 39.95 & 1.00 & \multirow{4}{*}{ gap $2.5 \mathrm{~mm}$} & & \\
\hline & & & & $0.01 w t \%$ & 44.67 & 1.12 & & & \\
\hline & & & & $0.05 \mathrm{wt} \%$ & 52.80 & 1.32 & & & \\
\hline & & & & $0.10 w \mathrm{t} \%$ & 59.81 & 1.50 & & & \\
\hline & & & & $0.00 \mathrm{wt} \%$ & 61.93 & 1.00 & \multirow{4}{*}{ gap 4 mm } & & \\
\hline & & & & $0.01 w t \%$ & 67.74 & 1.09 & & & \\
\hline & & & & $0.05 w \mathrm{t} \%$ & 79.68 & 1.29 & & & \\
\hline & & & & $0.10 w \mathrm{t} \%$ & 87.74 & 1.42 & & & \\
\hline \multirow{2}{*}{$\mathrm{SiO}_{2}$} & \multirow{2}{*}{ MO } & \multirow{2}{*}{ OA } & \multirow{2}{*}{-} & $0 \mathrm{vol} \%$ & 60.9 & 1.00 & & \multirow{2}{*}{ IEC 60156} & \multirow{2}{*}{ [99] } \\
\hline & & & & $20 \mathrm{vol} \%$ & 72.9 & 1.20 & & & \\
\hline \multirow{6}{*}{$\mathrm{SiO}_{2}$} & \multirow{6}{*}{$\mathrm{MO}$} & \multirow{6}{*}{$\mathrm{OA}$} & \multirow{6}{*}{20} & $0.00 \mathrm{vol} \%$ fr & 48.14 & 1.00 & & \multirow{6}{*}{ IEC 60156} & \multirow{6}{*}{ [100] } \\
\hline & & & & $0.01 \mathrm{vol} \% \mathrm{fr}$ & 58.24 & 1.21 & & & \\
\hline & & & & $0.02 \mathrm{vol} \%$ fr & 60.84 & 1.26 & & & \\
\hline & & & & $0.04 \mathrm{vol} \% \mathrm{fr}$ & 62.08 & 1.29 & & & \\
\hline & & & & $0.06 \mathrm{vol} \%$ fr & 63.90 & 1.33 & & & \\
\hline & & & & $0.15 \mathrm{vol} \%$ fr & 60.59 & 1.26 & & & \\
\hline
\end{tabular}


Table 4. Cont.

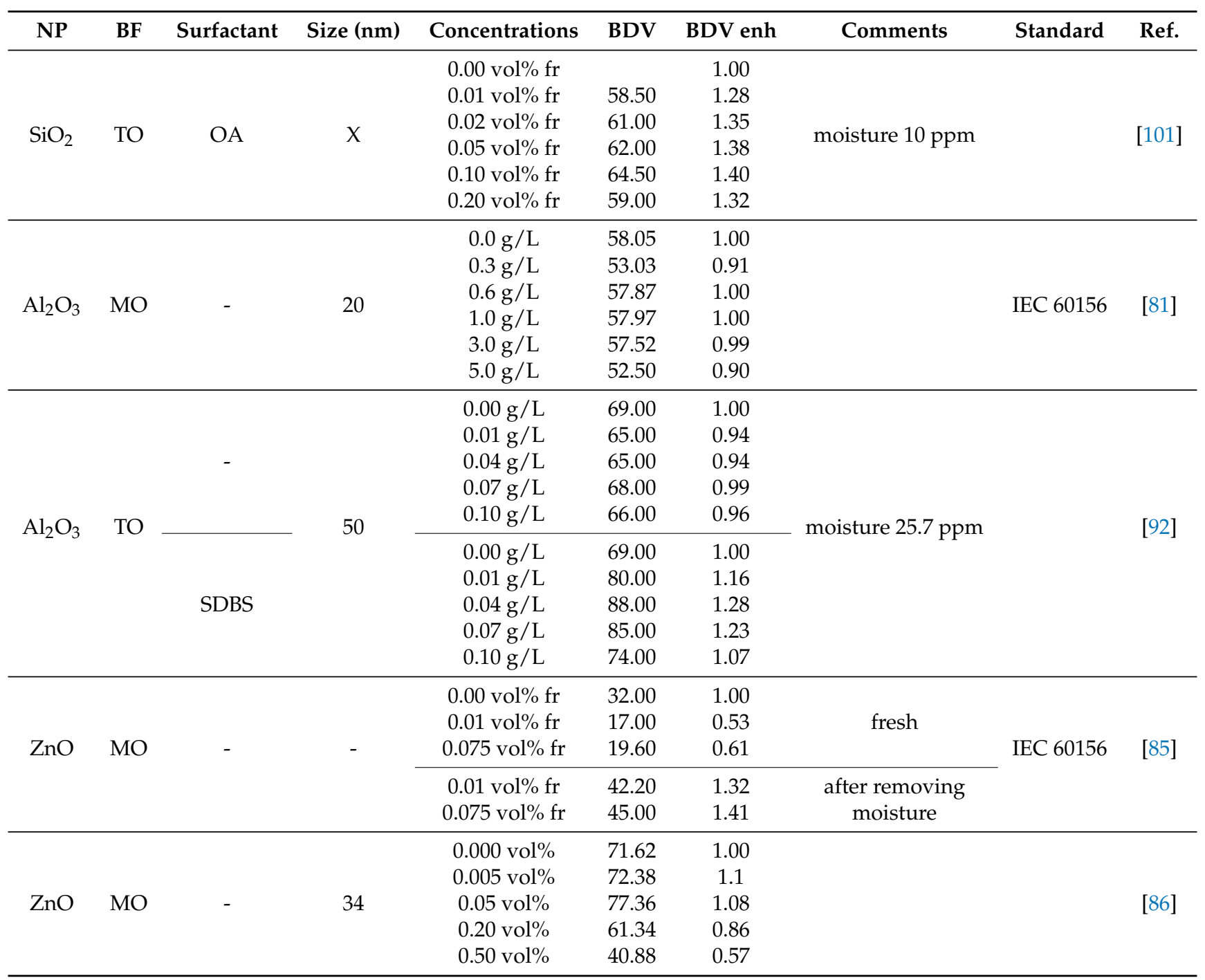


Table 4. Cont

\begin{tabular}{|c|c|c|c|c|c|c|c|c|c|}
\hline NP & BF & Surfactant & Size (nm) & Concentrations & BDV & BDV enh & Comments & Standard & Ref. \\
\hline \multirow{13}{*}{$\mathrm{ZnO}$} & $\mathrm{MO}$ & \multirow{13}{*}{$\begin{array}{l}\text { CTAB } \\
(3 \mathrm{~g} / \mathrm{L})\end{array}$} & \multirow{13}{*}{$<100$} & $0.00 \mathrm{~g} / \mathrm{L}$ & 19.80 & 1.00 & & \multirow{13}{*}{ ASTM D1816 } & \multirow{13}{*}{ [90] } \\
\hline & \multirow{6}{*}{ SBE } & & & $0.00 \mathrm{~g} / \mathrm{L}$ & 20.60 & 1.04 & & & \\
\hline & & & & $0.01 \mathrm{~g} / \mathrm{L}$ & 21.70 & 4.10 & & & \\
\hline & & & & $0.05 \mathrm{~g} / \mathrm{L}$ & 22.60 & 4.14 & & & \\
\hline & & & & $0.10 \mathrm{~g} / \mathrm{L}$ & 26.50 & 4.34 & & & \\
\hline & & & & $0.15 \mathrm{~g} / \mathrm{L}$ & 29.10 & 4.47 & & & \\
\hline & & & & $0.20 \mathrm{~g} / \mathrm{L}$ & 28.70 & 4.45 & & & \\
\hline & \multirow{6}{*}{ palm ester } & & & $0.00 \mathrm{~g} / \mathrm{L}$ & 18.90 & 0.95 & & & \\
\hline & & & & $0.01 \mathrm{~g} / \mathrm{L}$ & 20.00 & 1.10 & & & \\
\hline & & & & $0.05 \mathrm{~g} / \mathrm{L}$ & 21.60 & 1.09 & & & \\
\hline & & & & $0.10 \mathrm{~g} / \mathrm{L}$ & 26.20 & 1.32 & & & \\
\hline & & & & $0.15 \mathrm{~g} / \mathrm{L}$ & 26.80 & 1.35 & & & \\
\hline & & & & $0.20 \mathrm{~g} / \mathrm{L}$ & 27.30 & 1.38 & & & \\
\hline \multirow{4}{*}{ semiconducting } & \multirow{4}{*}{$\mathrm{MO}$} & \multirow{4}{*}{-} & \multirow{4}{*}{$<20$} & 0 & 71.59 & 1.00 & & \multirow{4}{*}{ IEC 60156} & \multirow{4}{*}[103]{} \\
\hline & & & & low & 78.68 & 1.10 & & & \\
\hline & & & & medium & 83.20 & 1.16 & & & \\
\hline & & & & high & 75.87 & 1.06 & & & \\
\hline \multirow{8}{*}{$\mathrm{Fe}_{3} \mathrm{O}_{4}$} & \multirow{8}{*}{$\mathrm{MO}$} & \multirow{8}{*}{-} & \multirow{8}{*}{-} & 0 & 50.00 & 1.00 & moisture & \multirow{8}{*}{ ASTM D877 } & \multirow{8}{*}{ [73] } \\
\hline & & & & $x$ & 50.00 & 1.00 & $<5$ ppm & & \\
\hline & & & & 0 & 43.00 & 0.86 & moisture & & \\
\hline & & & & $X$ & 47.00 & 0.94 & 10-20 ppm & & \\
\hline & & & & 0 & 37.00 & 0.74 & moisture & & \\
\hline & & & & $x$ & 44.00 & 0.88 & 20-30 ppm & & \\
\hline & & & & 0 & 28.00 & 0.56 & moisture & & \\
\hline & & & & $X$ & 40.00 & 0.80 & $>30 \mathrm{ppm}$ & & \\
\hline
\end{tabular}


Table 4. Cont.

\begin{tabular}{|c|c|c|c|c|c|c|c|c|c|}
\hline NP & BF & Surfactant & Size $(\mathrm{nm})$ & Concentrations & BDV & BDV enh & Comments & Standard & Ref. \\
\hline \multirow{29}{*}{$\begin{array}{c}\text { magnetic NP } \\
\text { (ferrofluid EFH-1) }\end{array}$} & \multirow{29}{*}{$\mathrm{MO}$} & \multirow{29}{*}{-} & & $0.000 \mathrm{vol} \%$ & 12.03 & 1.00 & \multirow{10}{*}{ gap $1.5 \mathrm{~mm}$} & \multirow{29}{*}{ IEC 156} & \multirow{29}{*}[104]{$*$} \\
\hline & & & & $0.082 \mathrm{vol} \%$ & 39.62 & 3.29 & & & \\
\hline & & & & $0.162 \mathrm{vol} \%$ & 37.03 & 3.08 & & & \\
\hline & & & & $0.238 \mathrm{vol} \%$ & 40.72 & 3.38 & & & \\
\hline & & & & $0.312 \mathrm{vol} \%$ & 37.79 & 3.14 & & & \\
\hline & & & & $0.385 \mathrm{vol} \%$ & 39.45 & 3.28 & & & \\
\hline & & & & $0.45 \mathrm{vol} \%$ & 42.79 & 3.56 & & & \\
\hline & & & & 0.52 vol $\%$ & 42.41 & 3.52 & & & \\
\hline & & & & 0.59 vol $\%$ & 42.17 & 3.50 & & & \\
\hline & & & & $0.65 \mathrm{vol} \%$ & 31.17 & 2.59 & & & \\
\hline & & & & $0.000 \mathrm{vol} \%$ & 12.62 & 1.00 & & & \\
\hline & & & & $0.082 \mathrm{vol} \%$ & 11.24 & 0.89 & & & \\
\hline & & & & $0.162 \mathrm{vol} \%$ & 26.69 & 2.11 & & & \\
\hline & & & & $0.238 \mathrm{vol}^{\%}$ & 32.72 & 2.59 & & & \\
\hline & & & - & $0.312 \mathrm{vol} \%$ & 32.21 & 2.55 & & & \\
\hline & & & & $0.385 \mathrm{vol} \%$ & 29.45 & 2.33 & gap $2.3 \mathrm{~mm}$ & & \\
\hline & & & & $0.45 \mathrm{vol}^{\%} \%$ & 33.76 & 2.67 & & & \\
\hline & & & & $0.000 \mathrm{vol} \%$ & 10.00 & 1.00 & \multirow{6}{*}{$\begin{array}{l}\text { without magnetic } \\
\text { field }\end{array}$} & & \\
\hline & & & & $0.082 \mathrm{vol} \%$ & 26.00 & 2.60 & & & \\
\hline & & & & $0.162 \mathrm{vol} \%$ & 32.50 & 3.25 & & & \\
\hline & & & & $0.238 \mathrm{vol} \%$ & 30.50 & 3.05 & & & \\
\hline & & & & $0.312 \mathrm{vol} \%$ & 31.70 & 3.17 & & & \\
\hline & & & & $0.385 \mathrm{vol} \%$ & 30.00 & 3.00 & & & \\
\hline & & & & $0.000 \mathrm{vol} \%$ & 12.50 & 1.00 & \multirow{6}{*}{$\begin{array}{l}\text { with magnetic } \\
\text { field }\end{array}$} & & \\
\hline & & & & $0.082 \mathrm{vol} \%$ & 41.00 & 3.28 & & & \\
\hline & & & & $0.162 \mathrm{vol} \%$ & 41.50 & 3.32 & & & \\
\hline & & & & $0.238 \mathrm{vol} \%$ & 41.50 & 3.32 & & & \\
\hline & & & & $0.312 \mathrm{vol} \%$ & 41.00 & 3.28 & & & \\
\hline & & & & $0.385 \mathrm{vol} \%$ & 41.50 & 3.32 & & & \\
\hline
\end{tabular}


Table 4. Cont.

\begin{tabular}{|c|c|c|c|c|c|c|c|c|c|}
\hline NP & BF & Surfactant & Size (nm) & Concentrations & BDV & BDV enh & Comments & Standard & Ref. \\
\hline $\begin{array}{c}\text { magnetic NP } \\
\text { (ferrofluid EFH-1) }\end{array}$ & $\mathrm{MO}$ & - & - & $\begin{array}{l}0.000 \mathrm{vol} \% \\
0.082 \mathrm{vol} \% \\
0.162 \mathrm{vol} \% \\
0.238 \mathrm{vol} \% \\
0.312 \mathrm{vol} \% \\
0.385 \mathrm{vol} \% \\
0.450 \mathrm{vol} \% \\
0.520 \mathrm{vol} \% \\
0.590 \mathrm{vol} \% \\
0.650 \mathrm{vol} \% \\
\end{array}$ & $\begin{array}{l}12.03 \\
39.62 \\
37.03 \\
40.72 \\
37.79 \\
39.45 \\
42.79 \\
42.41 \\
42.17 \\
31.17\end{array}$ & $\begin{array}{c}1.00 \\
3.29 \\
3.080 \\
3.38 \\
3.14 \\
3.28 \\
3.56 \\
3.52 \\
3.50 \\
2.59\end{array}$ & & IEC 156 & {$[105]^{*}$} \\
\hline $\mathrm{ZrO}_{2}$ & - & - & 50 & $\begin{array}{l}0.000 w \mathrm{wt} \% \\
0.005 w \mathrm{wt} \% \\
0.010 w \mathrm{w} \% \\
0.050 \mathrm{wt} \% \\
\end{array}$ & $\begin{array}{l}61.20 \\
67.34 \\
75.24 \\
66.13 \\
\end{array}$ & $\begin{array}{l}1.00 \\
1.10 \\
1.23 \\
1.08 \\
\end{array}$ & & IS 6792:1972 & [91] \\
\hline $\begin{array}{l}\text { fullerene } \\
\text { spherical }\end{array}$ & $\mathrm{MO}$ & - & 70 & $\begin{array}{l}0.00 \% \text { mas fr } \\
0.05 \% \text { mas fr } \\
0.10 \% \text { mas fr }\end{array}$ & $\begin{array}{l}51.00 \\
61.00 \\
69.00\end{array}$ & $\begin{array}{l}1.00 \\
1.20 \\
1.35\end{array}$ & & IEC 60156 & [109] \\
\hline $\begin{array}{c}\text { insulating } \\
\text { NP (metal oxide) }\end{array}$ & $\mathrm{TO}$ & - & - & $\begin{array}{l}0.00 \mathrm{~g} / \mathrm{L} \\
0.05 \mathrm{~g} / \mathrm{L}\end{array}$ & $\begin{array}{l}57.00 \\
81.70\end{array}$ & $\begin{array}{l}1.00 \\
1.43\end{array}$ & & IEC 60156 & [107] \\
\hline semiconducting & $\mathrm{TO}$ & - & - & $\begin{array}{l}0.00 \mathrm{~g} / \mathrm{L} \\
0.05 \mathrm{~g} / \mathrm{L}\end{array}$ & $\begin{array}{l}57.00 \\
65.10\end{array}$ & $\begin{array}{l}1.00 \\
1.14\end{array}$ & & IEC 60156 & [107] \\
\hline conductive & $\mathrm{TO}$ & - & - & $\begin{array}{l}0.00 \mathrm{~g} / \mathrm{L} \\
0.05 \mathrm{~g} / \mathrm{L}\end{array}$ & $\begin{array}{l}57.00 \\
70.30 \\
\end{array}$ & $\begin{array}{l}1.00 \\
1.23\end{array}$ & & IEC 60156 & [107] \\
\hline conductive & $\mathrm{MO}$ & - & $\begin{array}{c}15 / 5 X \\
10-50 \mu \mathrm{m}\end{array}$ & $\begin{array}{l}0.000 \mathrm{vol} \% \\
0.005 \mathrm{vol} \% \\
0.010 \mathrm{vol} \% \\
0.050 \mathrm{vol} \%\end{array}$ & $\begin{array}{l}25.00 \\
7.00 \\
6.00 \\
1.25\end{array}$ & $\begin{array}{l}1.00 \\
0.28 \\
0.24 \\
0.05\end{array}$ & & ASTM D1816 & [102] \\
\hline nanodiamond & $\mathrm{MO}$ & - & 6 & $\begin{array}{l}0.000 \mathrm{vol} \% \\
0.005 \mathrm{vol} \% \\
0.010 \mathrm{vol} \% \\
0.050 \mathrm{vol} \%\end{array}$ & $\begin{array}{c}25.00 \\
14.70 \\
9.80 \\
6.00\end{array}$ & $\begin{array}{l}1.00 \\
0.59 \\
0.39 \\
0.24\end{array}$ & & ASTM D1816 & [102] \\
\hline
\end{tabular}


Table 4. Cont

\begin{tabular}{|c|c|c|c|c|c|c|c|c|c|}
\hline NP & BF & Surfactant & Size (nm) & Concentrations & BDV & BDV enh & Comments & Standard & Ref. \\
\hline \multirow{5}{*}{ AlN } & \multirow{5}{*}{$\mathrm{MO}$} & \multirow{5}{*}{-} & \multirow{5}{*}{6} & $0.00 \mathrm{vol} \%$ & 88.00 & 1.00 & & \multirow{5}{*}{ ASTM D1816 } & \multirow{5}{*}{ [108] } \\
\hline & & & & oleic acid oil & 92.00 & 1.05 & & & \\
\hline & & & & $0.079 \mathrm{vol} \%$ & 126.00 & 1.43 & & & \\
\hline & & & & 0.127 vol $\%$ & 131.00 & 1.49 & & & \\
\hline & & & & $0.159 \mathrm{vol} \%$ & 131.00 & 1.49 & & & \\
\hline
\end{tabular}

* Data read from graph. $X$, no data available. 


\section{Lightning Impulse Breakdown Voltage of Nanofluids}

Not only the BDV magnitude of transformer oils is an important parameter, but also the lightning impulse breakdown voltage is a key factor for practical applications of nanoparticle insulating oil-based nanofluids in high voltage transformers, and that is why the LI BDV value of insulating oils is also of interest to researchers and engineers.

\subsection{Nitrides and Other Nanoparticles}

Iron oxide suspensions were studied by Liu et al. [110]. They investigated the lightning impulse breakdown voltage of magnetite $\left(\mathrm{Fe}_{3} \mathrm{O}_{4}\right)$ and maghemite $\left(\mathrm{Fe}_{2} \mathrm{O}_{3}\right)$ with the average size of nanoparticles in the range from 5-20 nm. To get better stability of nanofluids, they used an unspecified surfactant. They conducted examination according to the IEC 60897 standard using electrodes with the configuration of a needle/sphere and a lightning impulse of 1.2/50 $\mu$ s. After adding nanoparticles to the mineral oil, they observed an increase in positive impulse breakdown voltage by $13.93 \%$ and a decrease in negative impulse breakdown voltage by $18.31 \%$. Streamer velocity for both positive and negative impulse breakdown voltage values was lower than that in pure mineral oil $(1.77 \mathrm{~km} / \mathrm{s})$, and it was $0.97 \mathrm{~km} / \mathrm{s}$ and $1.01 \mathrm{~km} / \mathrm{s}$, respectively.

$\mathrm{Li}$ et al. [111] studied nanoparticles of $\mathrm{Fe}_{3} \mathrm{O}_{4}$ with a modified surface by oleic acid suspended in vegetable oil (rapeseed oil). The average size of used nanoparticles was $30 \mathrm{~nm}$ in diameter. Measurements of lightning impulse breakdown voltage were conducted according to the standard of IEC 60897. The electrode system was a steel needle/sphere with a $13 \mathrm{~mm}$ diameter of the sphere and distance between the electrodes of $15 \mathrm{~mm}$. The content of moisture in the vegetable oil and nanofluid was $288 \mathrm{mg} / \mathrm{kg}$ and $283 \mathrm{mg} / \mathrm{kg}$, respectively. They observed a $37.4 \%$ and a $11.8 \%$ increase for the nanofluid containing $\mathrm{Fe}_{3} \mathrm{O}_{4}$ nanoparticles, respectively for positive and negative LI BDV. Li et al. also noticed that the time to lightning impulse breakdown voltage of nanofluids was greater than for pure oil, and it was $21.2 \%$ and $14.4 \%$, respectively. Li et al. [66] also studied a suspension of $\mathrm{Fe}_{3} \mathrm{O}_{4}$ nanoparticles in vegetable oil. Measurements were conducted according to the IEC standard for positive and negative impulse breakdown voltage. The average from five measurements showed that positive LI BDV was $37 \%$ higher than the pure oil sample. On the other hand, negative LI BDV was only $12 \%$ higher than the pure oil sample. Furthermore, the average streamer velocity for both positive and negative LI BDV was increased by $21 \%$ and $14 \%$, respectively. Ghasemi et al. [112] investigated the ability to improve lightning BDV in transformer oil of $\mathrm{Fe}_{3} \mathrm{O}_{4}$ nanoparticles with three different volume concentrations $(0.20,0.40,0.60 \%)$. The surface of nanoparticles was modified using oleic acid, which allowed achieving the stability of nanofluids without a precipitation longer than four months. They used two spherical electrodes with a $2.5 \mathrm{~mm}$ distance between them and a 1.2/50 $\mu$ s impulse. The measurement setup is presented in Figures 6 and 7.

The findings indicate that the addition of iron oxide nanoparticles to the transformer oil was favorable in some ranges of the volume concentration of nanoparticles. The optimum improvement in LI BDV was achieved for $0.3 \mathrm{vol} \%$, and it was $16 \%$ more than pure oil. Yang et al. [113] measured the impulse breakdown in oil samples containing dispersed $10 \mathrm{~nm}$ nanoparticles of $\mathrm{Fe}_{3} \mathrm{O}_{4}$ with a concentration of $0.03 \mathrm{~g} / \mathrm{L}$. For this purpose, they used the improved traditional Kerr electrooptic field mapping technique [114]. The picture of the measurement setup is presented in Figure 8.

They used two parallel plate electrodes made of aluminum with a $3 \mathrm{~mm}$ distance between them and a photodetector array. A voltage waveform of 150/500 $\mu$ s was used in this study. They found that the mean breakdown voltage for transformer oil with nanoparticles was higher by $11.2 \%$ than that of pure oil. On the other hand, the time to breakdown voltage was decreased by the addition of nanoparticles by $38.5 \%$. The positive and negative impulse breakdown voltages for the the suspension of iron oxide in mineral oil were measured also by Rafiq et al. $[69,115]$. The scheme of the measuring cell for this type of test is presented in Figure 9. 


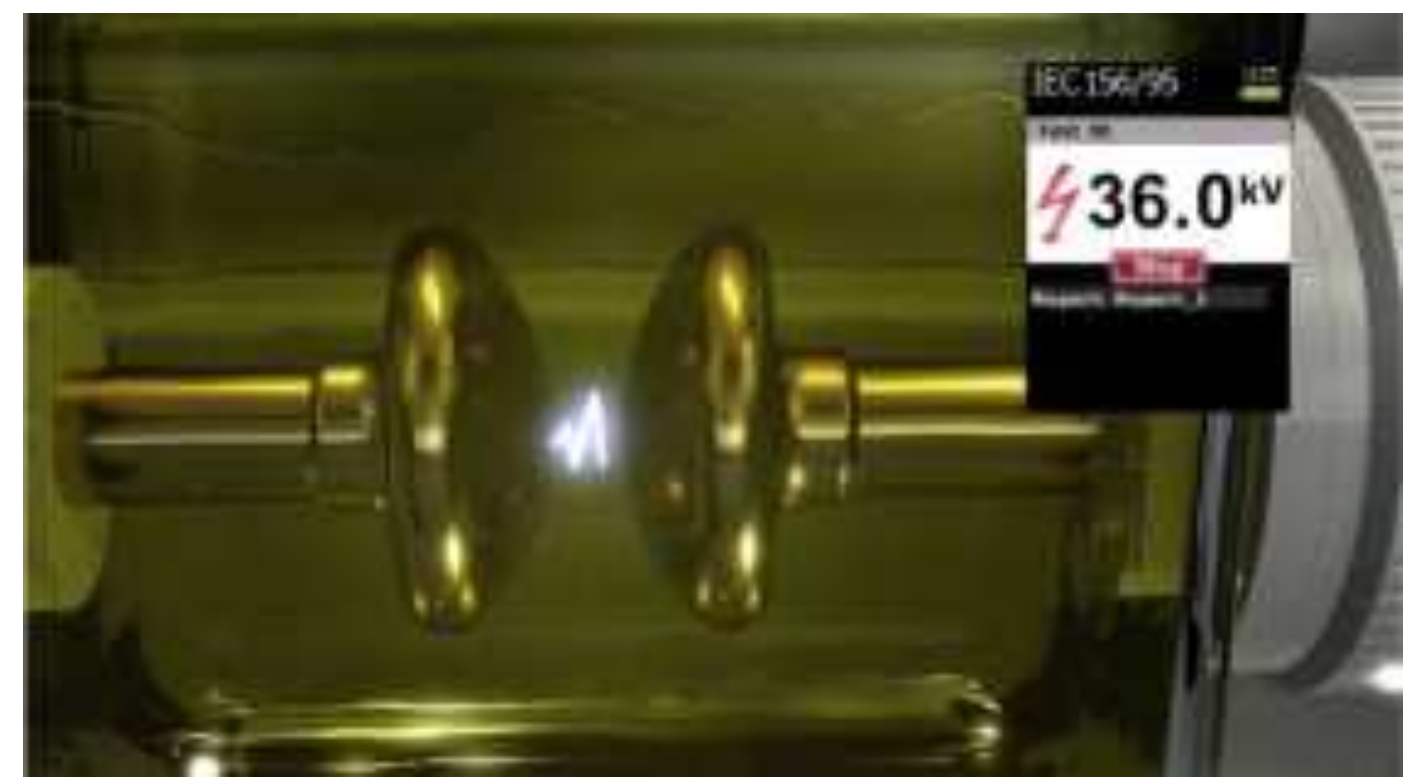

Figure 6. View of the measuring cell during the BDV test. Reproduced with permission from [112].

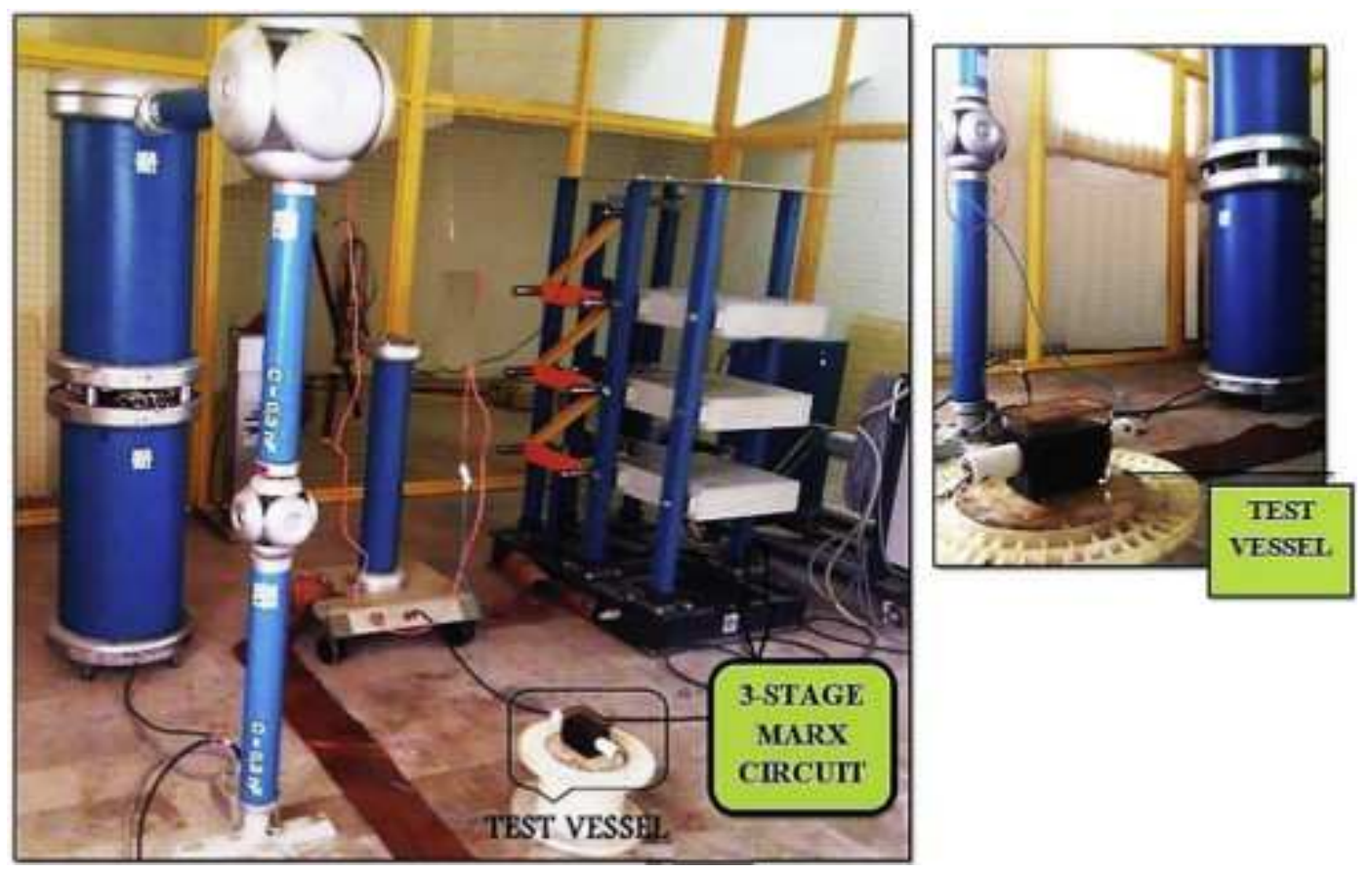

Figure 7. Impulse wave generator and measuring stand. Reproduced with permission from [112]. 


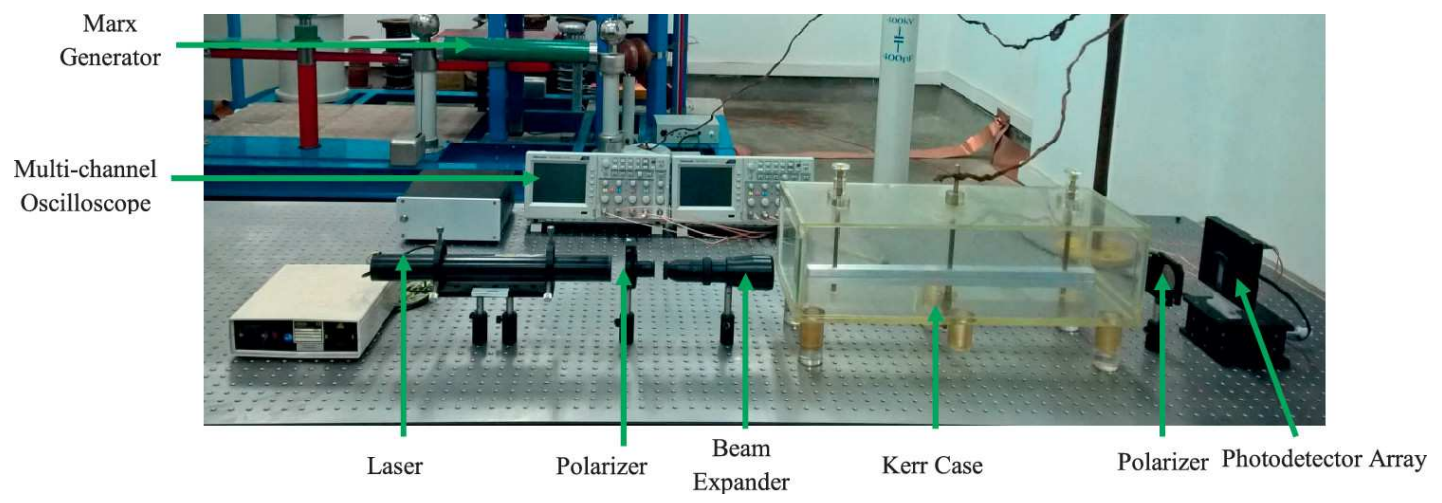

Figure 8. Photo of the measuring stand for Kerr electrooptic mapping measurements. Reproduced under the conditions of the Creative Commons Attribution license from [113].

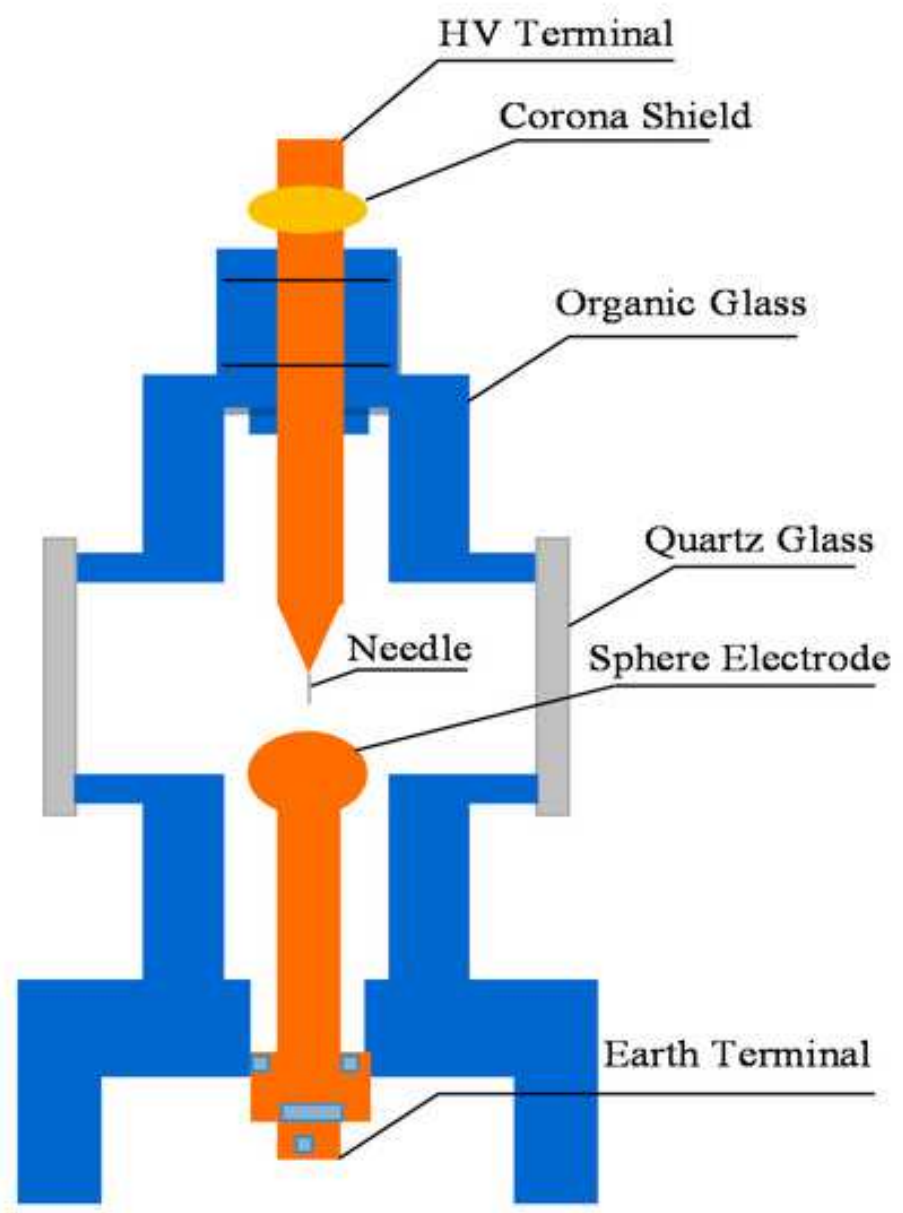

Figure 9. The scheme of the measuring cell for the LI BDV test. Reproduced under the conditions of the Creative Commons Attribution license from [115].

Similar to AC BDV, the maximum enhancement of positive LI BDV was achieved for a $0.4 \mathrm{~g} / \mathrm{L}$ concentration of nanoparticles, and it was greater than 1.36 times in comparison to pure mineral oil; whereas, negative LI BDV constantly decreased with increasing concentration and dropped by $36 \%$ as compared to pure oil. In another paper, Rafiq et al. [70] examined the insulating properties of a suspension of magnetic $\mathrm{Fe}_{3} \mathrm{O}_{4}$ nanoparticles and mineral oil with one unknown concentration. Results showed that the addition of $\mathrm{Fe}_{3} \mathrm{O}_{4}$ nanoparticles increased in PLI BDV by 1.36 times. On the 
other hand, the values of NLI BDV decreased by the addition of magnetic nanoparticles by 0.85 times. Ramu et al. [116] studied transformer oil with $\mathrm{Fe}_{3} \mathrm{O}_{4}$ nanoparticles and tested their influence on both positive and negative lightning impulse (NLI) BDV. For this purpose, they employed a pair of needle/sphere electrodes according to the IEC standard and found an $81.4 \%$ increase in LI BDV for positive and a $9.4 \%$ decrease for negative LI BDV. Pure natural ester oil and their LI BDV properties were also studied by $\mathrm{Li}$ et al. [117]. The effect of $\mathrm{Fe}_{3} \mathrm{O}_{4}$ nanoparticles was also investigated. They found that inclusions of $\mathrm{Fe}_{3} \mathrm{O}_{4}$ could improve the LI BIDV properties of natural ester oil. Positive and negative lightning breakdown voltages were increased by $37 \%$ and $12 \%$, respectively.

\subsection{Titanium Oxide Nanoparticles}

Lv et al. [78] studied the lightning impulse breakdown voltage of transformer oil containing stearic acid-modified $\mathrm{TiO}_{2}$ nanoparticles with various concentrations. All measurements were conducted in accordance with the IEC 60897 standard with a 1.2/50 $\mu$ s impulse. They observed improvements in LI $\mathrm{BDV}$ in a concentration ranging from $0.003-0.03 \mathrm{~g} / \mathrm{L}$, and the maximum enhancement was achieved for the highest examined concentration, being $17 \%$. Yue et al. [79] measured $\mathrm{LI} \mathrm{BDV}$ in $\mathrm{TiO}_{2}$ transformer oil-based nanofluids. Five samples with concentrations in the range of $0.003-0.05 \mathrm{~g} / \mathrm{L}$ were studied according to the IEC 60897 standard using a 1.2/50 $\mu$ s voltage impulse and a $25 \mathrm{~mm}$ distance between electrodes. Results indicated that the addition of $\mathrm{TiO}_{2}$ nanoparticles to transformer oil enhanced LI BDV. The maximum enhancement was achieved for $0.03 \mathrm{~g} / \mathrm{L}$, and it was $16.7 \%$ higher than that of pure oil. LI BDV for transformer oil with $\mathrm{TiO}_{2}$ nanoparticles was also studied by Du et al. [80]. They conducted measurements based on the ASTM D3300 standard. Their results showed a 24\% increase in LI BDV for this type of fluids in comparison to pure transformer oil, and the time to BDV increased $53.3 \%$ as well. $\mathrm{Lv}$ et al. [81] studied the $\mathrm{LI} \mathrm{BDV}$ of $\mathrm{TiO}_{2}$ transformer oil nanofluid with various concentrations and concluded that LI BDV increased in the concentration range from $0.3-0.6 \%$, the maximum enhancement being 13\%. Measurements were conducted in line with the IEC 60897 standard at room temperature. Mutian et al. [82] reported increases in the positive lightning (PLI) breakdown voltage for mineral oils enriched with $\mathrm{TiO}_{2}$ nanoparticles. They observed $47 \%$ enhancement in PLI BDV for this type of nanofluid, and also, the time to breakdown was increased from $14.27 \mu \mathrm{s}-25.11 \mu \mathrm{s}$. Du et al. [75] studied LI BDV for mineral oil with $\mathrm{TiO}_{2}$ nanoparticles with a $0.075 \%$ by volume concentration. They observed that the presence of $\mathrm{TiO}_{2}$ nanoparticles in the mineral oil increased LI BDV by $24 \%$, and the time to breakdown also increased from $15.2 \mu \mathrm{s}-23.3 \mu \mathrm{s}$. Hu et al. [88] studied the LI BDV of mineral oil with $\mathrm{TiO}_{2}$ nanoparticles after heating at $130{ }^{\circ} \mathrm{C}$ for 36 days. They performed measurements of LI BDV every six days. For the first 18 days, they observed approximately 1.3 times higher values of LI BDV for nanofluid in comparison to pure oil. After, this time difference between pure oil and nanofluids was negligible. In both cases, LI BDV was decreasing with increasing aging time. Rafiq et al. [76] studied the LI BDV of mineral oil with dispersed $\mathrm{TiO}_{2}$ nanoparticles for fresh samples and after six days in $130^{\circ} \mathrm{C}$. They found that LI BDV increased by $23 \%$ and $47 \%$ for fresh and aged samples, respectively. Pugazhendhi et al. [91] studied the $\mathrm{LI} \mathrm{BDV} \mathrm{of} \mathrm{TiO}_{2}$ nanoparticles suspended in transformer oil with three mass concentrations $(0.005,0.01,0.05 \%)$. Their investigations revealed that the maximum improvement for this type of nanofluid was $19 \%$ for a $0.005 \mathrm{wt} \%$ concentration.

\subsection{Silicon Oxide Nanoparticles}

Liu et al. [110] prepared mineral oil-based nanofluid containing a $0.04 \mathrm{vol} \%$ concentration of $\mathrm{SiO}_{2}$ nanoparticles modified by surfactant and compared its LI BDV to pure mineral oil according to the IEC 60897 standard. They found a 9\% decrease in PLI BDV in comparison to the pure oil sample; on the other hand, the value of NLI BDV was almost unchanged. Furthermore, an impact on streamer velocity was observed for both positive and negative $\mathrm{LI} B D V$, and it was a $4.5 \%$ increase and a $22 \%$ decrease for PLI BDV and NLI BDV, respectively. LI BDV of $\mathrm{SiO}_{2}$ nanoparticles dispersed in mineral oil were also studied by Ramu et al. [116]. They measured LI BDV using a self-made measuring stand, prepared in line with the suggestions of the ASTM and IEC standards. The values of the positive and 
negative LI BDV showed a different behavior under the presence of $\mathrm{SiO}_{2}$ nanoparticles. PLI BDV was increased by $81 \%$, while NLI BDV was decreased by $4 \%$. Similar situations were observed for the time to breakdown voltage, where its observed $41.7 \%$ increase and $4 \%$ decrease for positive and negative LI $\mathrm{BDV}$, respectively, was reported. Streamer velocity was increased for both positive and negative LI BDV. The impact of $\mathrm{SiO}_{2}$ nanoparticles with a $20 \mathrm{vol} \%$ concentration on insulating mineral oil was studied by Rafiq and Lv [99]. They found that PLI BDV increased 1.11 times, but, on the other hand, NLI BDV reduced 0.93 times. Similar behavior was observed in the time to BDV.

\subsection{Aluminum Oxide Nanoparticles}

Liu et al. [110] studied $\mathrm{Al}_{2} \mathrm{O}_{3}$ nanoparticles with a diameter ranging from 5-20 nm modified by surfactant and dispersed in transformer oil with a $0.1425 \mathrm{vol} \%$ concentration. They measured positive and negative LI BDV according to the IEC 60897 standard and found a decrease in both, $12 \%$ and 13\% for positive and negative LI BDV, respectively.

\subsection{Others Nanoparticles}

Jian et al. [103] studied the LI BDV of mineral oil with semiconductive nanoparticles with three different concentrations. They conducted measurements using the ASTM D3300 standard and found that LI BDV increased with increasing concentration of nanoparticles. The maximum enhancement was observed for the highest semiconductive nanoparticles concentration. Segal et al. [73] measured the LI BDV of two mineral oils with magnetite nanoparticles according to the ASTM D3300 standard for a $25.4 \mathrm{~mm}$ and a $55 \mathrm{~mm}$ gap. They found that LI BDV increased with increasing the gap. Effect of nanoparticles concentration in base fluids was also observed. Positive lightning impulse breakdown voltage for both mineral oils was enhanced at least $80 \%$. On the other hand, negative lightning impulse breakdown was decreased by at least $2 \%$. Dispersion of $\mathrm{ZrO}_{2}$ in transformer oil and their LI BDV was investigated by Pugazhendhi et al. [91]. They performed measurements and revealed that addition of $\mathrm{ZrO}_{2}$ nanoparticles with a $0.005 \mathrm{wt} \%$ concentration to transformer oil caused the maximum increase in LI BDV, and it was 16\%; also, other samples showed improvement in LI BDV. Lv et al. [107] studied the LI BDV properties of mineral oil with the inclusion of three types of nanoparticles (insulating, semi-conducting, conducting) with a $0.05 \mathrm{~g} / \mathrm{L}$ concentration and found an increase in LI BDV for each of them, being $7 \%, 8 \%$ and $1 \%$ for insulating, semi-conducting and conducting nanoparticles, respectively. Liu et al. [110] used $\mathrm{ZnO}$ nanoparticles with a modified surface by surfactant to change the insulating properties of mineral oil. They prepared nanofluid using $\mathrm{ZnO}$ nanoparticles with a diameter in the range $5-20 \mathrm{~nm}$ with a $0.0475 \mathrm{vol} \%$ concentration. LI BDV was measured according to the IEC 60897 standard, and the obtained results exhibited a decrease in both positive and negative values of LI BDV. The addition of a $0.0475 \mathrm{vol} \%$ concentration to mineral oil caused a $3.4 \%$ and a $34.5 \%$ decrease in the positive and negative LI BDV, respectively.

The results of all AC LI BDV measurements discussed in this review are summarized in Table 5 and plotted in Figure 10. 


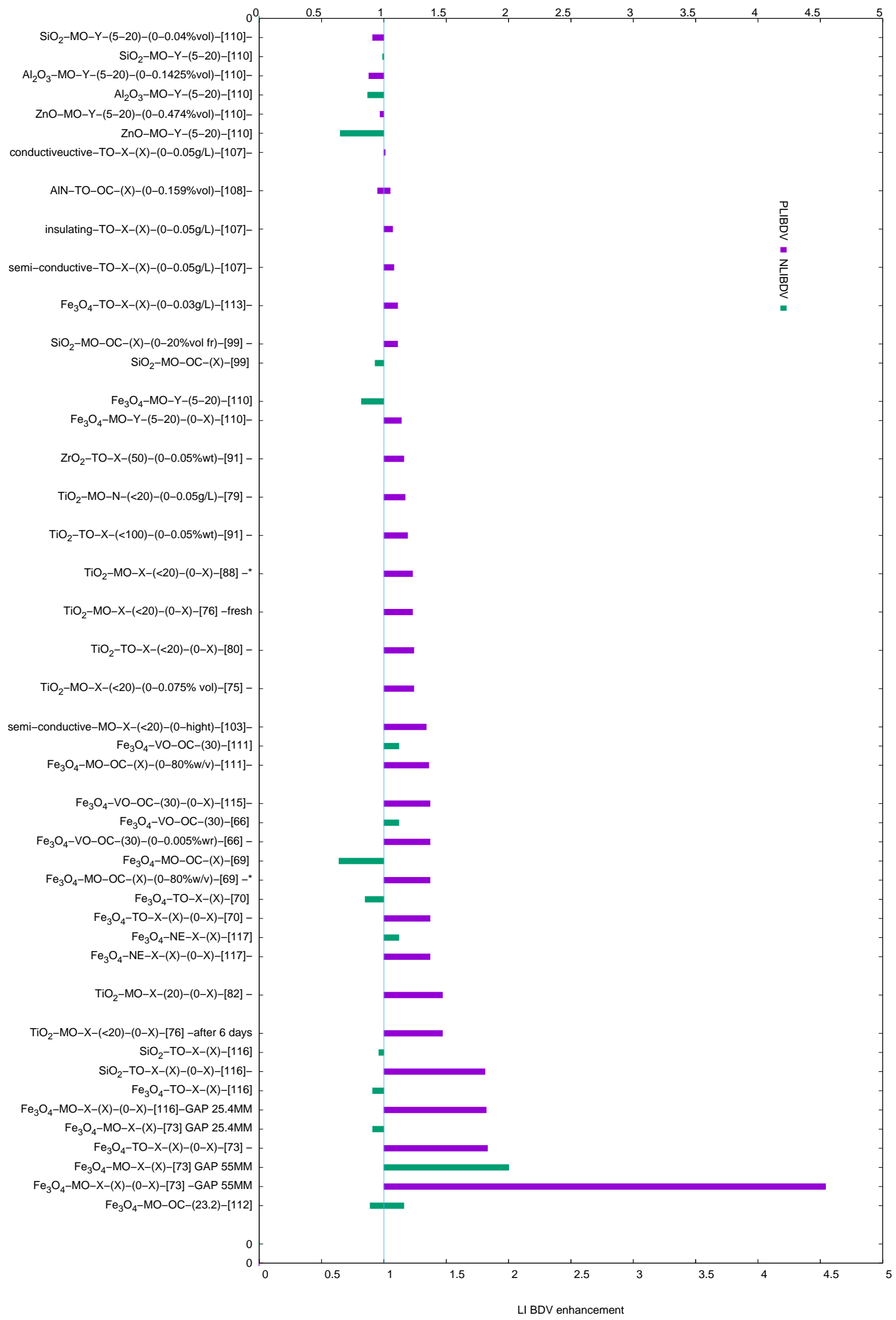

Figure 10. Range of enhancement in LI BDV values of nanoparticle oil-based nanofluids. Structure of legend: nanoparticle-based fluid-surfactant-(nanoparticle size)-(concentration range)-ref. $X$, no data available; N, no surfactant; Y, with surfactant, but unspecified; *, data read from graph. 
Table 5. Summary of the lightning impulse breakdown voltage for various nanofluids.

\begin{tabular}{|c|c|c|c|c|c|c|c|c|c|c|c|c|c|c|c|}
\hline $\mathrm{NP}$ & $\mathrm{BF}$ & Surfactant & Size (nm) & Concentrations & PL BDV & $\mathrm{PL} \mathrm{BDV}_{n f} / \mathrm{PL} \mathrm{BDV}_{b f}$ & NL BDV & $\mathrm{NL} \mathrm{BDV}_{n f} / \mathrm{NL} \mathrm{BDV}_{b f}$ & Time + & Time - & Stream + & Stream - & Comments & Standard & Ref. \\
\hline $\mathrm{Fe}_{3} \mathrm{O}_{4}$ & MO & Yes & $5-20$ & $\begin{array}{l}0 \\
X\end{array}$ & $\begin{array}{c}98.77 \\
112.53\end{array}$ & $\begin{array}{c}1 \\
1.139\end{array}$ & $\begin{array}{l}-156.56 \\
-127.9\end{array}$ & $\begin{array}{c}1 \\
0.82\end{array}$ & & & $\begin{array}{l}1.77 \\
0.97\end{array}$ & $\begin{array}{l}1.77 \\
1.01\end{array}$ & & IEC 60897 & [110] \\
\hline $\mathrm{Fe}_{3} \mathrm{O}_{4}$ & vo & $\mathrm{OA}$ & 30 & $\begin{array}{l}0 \\
\mathrm{X}\end{array}$ & $\begin{array}{c}73.9 \\
101.5\end{array}$ & $\begin{array}{c}1 \\
1.373\end{array}$ & $\begin{array}{l}83.8 \\
93.7\end{array}$ & $\begin{array}{c}1 \\
1.12\end{array}$ & $\begin{array}{l}9.9 \\
12\end{array}$ & $\begin{array}{l}11.1 \\
12.7\end{array}$ & & & & IEC 60897 & [111] \\
\hline $\mathrm{Fe}_{3} \mathrm{O}_{4}$ & vo & $\mathrm{OA}$ & 30 & $\begin{array}{l}0.000 \% \text { wr } \\
0.004 \% \text { wr }\end{array}$ & $\begin{array}{c}73.9 \\
101.5\end{array}$ & $\begin{array}{c}1 \\
1.373\end{array}$ & $\begin{array}{l}83.8 \\
93.7\end{array}$ & $\begin{array}{c}1 \\
1.12\end{array}$ & $\begin{array}{l}9.9 \\
12\end{array}$ & $\begin{array}{l}11.1 \\
12.7\end{array}$ & & & & IEC 60897 & [66] \\
\hline $\mathrm{Fe}_{3} \mathrm{O}_{4}$ & то & - & - & $\begin{array}{l}0 \\
\mathrm{X}\end{array}$ & $\begin{array}{l}86 \\
157\end{array}$ & $\begin{array}{c}1 \\
1.826\end{array}$ & $\begin{array}{l}170 \\
154\end{array}$ & $\begin{array}{c}1 \\
0.91\end{array}$ & $\begin{array}{l}12 \\
26\end{array}$ & $\begin{array}{l}27 \\
15\end{array}$ & $\begin{array}{l}2.12 \\
0.98\end{array}$ & $\begin{array}{l}0.94 \\
1.69\end{array}$ & & & [116] \\
\hline $\mathrm{Fe}_{3} \mathrm{O}_{4}$ & MO & OA & 23.2 & $\begin{array}{l}0.0 \mathrm{vol} \% \\
0.2 \mathrm{vol} \% \\
0.3 \mathrm{vol} \% \\
0.6 \mathrm{vol} \%\end{array}$ & & & $\begin{array}{l}151.1 \\
159.4 \\
175.4 \\
134.6\end{array}$ & $\begin{array}{c}1 \\
1.05 \\
1.16 \\
0.89\end{array}$ & & & & & & & [112] \\
\hline $\mathrm{Fe}_{3} \mathrm{O}_{4}$ & TO & - & - & $\begin{array}{c}0 . \mathrm{g} / \mathrm{L} \\
0.3 \mathrm{~g} / \mathrm{L}\end{array}$ & $\begin{array}{l}99.1 \\
110.2 \\
\end{array}$ & $\begin{array}{c}1 \\
1.112 \\
\end{array}$ & & & $\begin{array}{l}306 \\
188 \\
\end{array}$ & & & & & & [113] \\
\hline $\mathrm{Fe}_{3} \mathrm{O}_{4}$ & MO & $\mathrm{OA}$ & - & $\begin{array}{l}0 \% w / v \\
5 \% w / v \\
10 \% w / v \\
20 \% w / v \\
40 \% w / v \\
60 \% w / v \\
80 \% w / v \\
\end{array}$ & $\begin{array}{c}79.24 \\
83.56 \\
84.08 \\
93.47 \\
107.47 \\
102.36 \\
88.07 \\
\end{array}$ & $\begin{array}{c}1 \\
1.05 \\
1.06 \\
1.18 \\
1.37 \\
1.3 \\
1.11 \\
\end{array}$ & $\begin{array}{c}124.79 \\
122.7 \\
119.71 \\
115.57 \\
106.19 \\
92.14 \\
80.3 \\
\end{array}$ & $\begin{array}{c}1 \\
0.98 \\
0.96 \\
0.93 \\
0.85 \\
0.74 \\
0.64 \\
\end{array}$ & $\begin{array}{l}12.87 \\
14.82 \\
18.32 \\
21.19 \\
25.33 \\
25.08 \\
21.98 \\
\end{array}$ & & \begin{tabular}{l|}
1.94 \\
1.68 \\
1.36 \\
1.17 \\
0.98 \\
0.99 \\
1.13 \\
\end{tabular} & & & IEC 60897 & [69] * \\
\hline $\mathrm{Fe}_{3} \mathrm{O}_{4}$ & TO & - & - & $\begin{array}{l}0 \\
X\end{array}$ & $\begin{array}{l}79.38 \\
108.5\end{array}$ & $\begin{array}{c}1 \\
1.367\end{array}$ & $\begin{array}{l}124.75 \\
106.3\end{array}$ & $\begin{array}{l}1.00 \\
0.85\end{array}$ & $\begin{array}{l}12.87 \\
25.33\end{array}$ & $\begin{array}{l}14.26 \\
11.03\end{array}$ & $\begin{array}{l}1.94 \\
0.98\end{array}$ & $\begin{array}{l}1.05 \\
1.36\end{array}$ & & IEC 60897 & [70] \\
\hline \multirow{3}{*}{$\mathrm{Fe}_{3} \mathrm{O}_{4}$} & \multirow{3}{*}{ MO } & \multirow{3}{*}{$\mathrm{OA}$} & $\begin{array}{c}0 \\
10 \\
20 \\
40\end{array}$ & $\begin{array}{c}0 \% w / v \\
5 \% w / v \\
10 \% w / v \\
20 \% w / v \\
40 \% w / v \\
60 \% w / v \\
0 \% w / v / v \\
40 \% w / v \\
40 \% w / v \\
40 \% w / v\end{array}$ & $\begin{array}{c} \\
79.36 \\
88.03 \\
108.09 \\
87.8\end{array}$ & $\begin{array}{c}1 \\
1.054 \\
1.062 \\
1.184 \\
1.366 \\
1.3 \\
\end{array}$ & $\begin{array}{c} \\
124.78 \\
97.89 \\
83.56 \\
114.47\end{array}$ & . & $\begin{array}{l}12.87 \\
14.82 \\
18.32 \\
21.19 \\
25.33 \\
25.08 \\
\end{array}$ & & $\begin{array}{l}1.94 \\
1.68 \\
1.36 \\
1.17 \\
0.98 \\
0.99 \\
\end{array}$ & & & \multirow{3}{*}{ IEC 60897} & \multirow{3}{*}{ [115] } \\
\hline & & & 20 & $\begin{array}{c}\text { gap (mm) } \\
5 \\
10 \\
15 \\
20 \\
30 \\
40\end{array}$ & $\begin{array}{c}67.82 \\
99.5 \\
127.27 \\
157.45 \\
175.59 \\
218.61\end{array}$ & & $\begin{array}{c}85.24 \\
102.54 \\
106.55 \\
132.07 \\
151.61 \\
172.67\end{array}$ & & & & & & Concentration $40 \%$ & & \\
\hline & & & 0 & $\begin{array}{c}\text { gap (mm) } \\
5 \\
10 \\
15 \\
20 \\
30 \\
40\end{array}$ & $\begin{array}{l}62.22 \\
93.16 \\
114.93 \\
117.78 \\
132.84 \\
162.96\end{array}$ & & $\begin{array}{c}89.22 \\
80.62 \\
90.44 \\
111.91 \\
131.66 \\
156.62\end{array}$ & & & & & & Concentration 0\% & & \\
\hline
\end{tabular}


Table 5. Cont

\begin{tabular}{|c|c|c|c|c|c|c|c|c|c|c|c|c|c|c|c|}
\hline $\mathrm{NP}$ & BF & Surfactant & Size (nm) & Concentrations & PL BDV & PL $\operatorname{BDV}_{n f} /$ PL BDV $\mathbf{B D}_{b f}$ & NL BDV & $\mathrm{NL}_{\mathbf{B D V}_{n f}} / \mathrm{NL}^{\mathrm{BDV}} \mathrm{b}_{b f}$ & Time + & Time - & Stream + & Stream - & Comments & Standard & Ref. \\
\hline $\mathrm{Fe}_{3} \mathrm{O}_{4}$ & $\mathrm{NE}$ & - & - & $\begin{array}{l}0 \\
\mathrm{X}\end{array}$ & $\begin{array}{l}73.9 \\
101.5\end{array}$ & $\begin{array}{c}1 \\
1.373\end{array}$ & $\begin{array}{l}83.8 \\
93.7\end{array}$ & $\begin{array}{c}1 \\
1.12\end{array}$ & & & & & & & [117] \\
\hline $\mathrm{TiO}_{2}-\mathrm{r}$ & MO & no & $<20$ & $\begin{array}{c}0.003 \mathrm{~g} / \mathrm{L} \\
0.006 \mathrm{~g} / \mathrm{L} \\
0.01 \mathrm{~g} / \mathrm{L} \\
0.03 \mathrm{~g} / \mathrm{L} \\
0.05 \mathrm{~g} / \mathrm{L} \\
\end{array}$ & \begin{tabular}{|c|}
79.7 \\
86.4 \\
85.8 \\
89.4 \\
93 \\
\end{tabular} & $\begin{array}{c}1 \\
1.084 \\
1.077 \\
1.122 \\
1.167 \\
\end{array}$ & & & $\begin{array}{c}14 \\
15.5 \\
16 \\
15.5 \\
16 \\
\end{array}$ & & & & & & [79] \\
\hline $\mathrm{TiO}_{2}$ & TO & - & $<20$ & $\begin{array}{l}0 \\
x\end{array}$ & $\begin{array}{l}77.6 \\
95.9\end{array}$ & $\begin{array}{c}1 \\
1.236\end{array}$ & & & $\begin{array}{l}15.2 \\
23.3\end{array}$ & & & & & ASTM D3300 & [80] \\
\hline $\mathrm{TiO}_{2}$ & MO & - & 20 & $\begin{array}{l}0 \\
x \\
\end{array}$ & $\begin{array}{l}70.25 \\
103.33 \\
\end{array}$ & $\begin{array}{c}1 \\
1.471 \\
\end{array}$ & & & $\begin{array}{l}14.27 \\
25.11\end{array}$ & & & & & & [82] \\
\hline $\mathrm{TiO}_{2}$ & MO & - & $<20$ & $\begin{array}{c}0 \text { vol } \% \\
0.075 \mathrm{vol} \% \\
\end{array}$ & $\begin{array}{l}77.6 \\
95.9\end{array}$ & $\begin{array}{c}1 \\
1.24\end{array}$ & & & $\begin{array}{l}15.2 \\
23.3\end{array}$ & & & & & ASTM D3300 & [75] \\
\hline $\mathrm{TiO}_{2}$ & MO & - & $<20$ & $\begin{array}{c}\text { time (day) } \\
0 \\
6 \\
12 \\
18 \\
24 \\
30 \\
36 \\
0 \\
6 \\
12 \\
18 \\
24 \\
30 \\
36 \\
\end{array}$ & $\begin{array}{c}77.64 \\
76.41 \\
69.75 \\
72.57 \\
69.52 \\
69.56 \\
69.33 \\
96.2 \\
102.78 \\
96.3 \\
73.29 \\
70.89 \\
77.75 \\
70.82 \\
\end{array}$ & $\begin{array}{c}1 \\
0.98 \\
0.90 \\
0.93 \\
0.90 \\
0.90 \\
0.89 \\
1.00 \\
1.07 \\
1.00 \\
0.76 \\
0.74 \\
0.74 \\
0.74 \\
\end{array}$ & & & & & & & pure oil & IEC 60897 & [88] \\
\hline \multirow{2}{*}{$\mathrm{TiO}_{2}$} & \multirow{2}{*}{ MO } & \multirow{2}{*}{ - } & \multirow{2}{*}{$<20$} & $\begin{array}{l}0 \\
x \\
\end{array}$ & & $\begin{array}{c}1 \\
1.23 \\
\end{array}$ & & & & & & & fresh & \multirow{2}{*}{ IEC 60897} & \multirow{2}{*}{ [76] } \\
\hline & & & & $\begin{array}{l}0 \\
X \\
\end{array}$ & & $\begin{array}{c}1 \\
1.47 \\
\end{array}$ & & & & & & & after 6 days & & \\
\hline $\mathrm{TiO}_{2}$ & TO & - & $<100$ & $\begin{array}{l}0.000 \mathrm{wt} \% \\
0.005 \mathrm{wt} \% \\
0.010 \mathrm{wt} \% \\
0.050 \mathrm{w} t \%\end{array}$ & $\begin{array}{l}34.13 \\
40.70 \\
38.90 \\
37.30\end{array}$ & $\begin{array}{l}1.000 \\
1.192 \\
1.140 \\
1.093\end{array}$ & & & & & & & & IS 11697:1986 & [91] \\
\hline $\mathrm{SiO}_{2}$ & MO & yes & $5-20$ & $\begin{array}{l}0.00 \mathrm{vol} \% \\
0.04 \mathrm{vol} \%\end{array}$ & $\begin{array}{l}98.77 \\
90.11\end{array}$ & $\begin{array}{c}1 \\
0.91\end{array}$ & $\begin{array}{l}-156.56 \\
-156.42\end{array}$ & $\begin{array}{c}1 \\
0.99\end{array}$ & & & $\begin{array}{l}1.77 \\
1.85\end{array}$ & $\begin{array}{l}1.77 \\
1.38\end{array}$ & & IEC 60897 & [110] \\
\hline $\mathrm{SiO}_{2}$ & TO & - & - & $\begin{array}{l}0 \\
\mathrm{x} \\
\end{array}$ & $\begin{array}{c}86 \\
156 \\
\end{array}$ & $\begin{array}{c}1 \\
1.814 \\
\end{array}$ & $\begin{array}{l}170 \\
163\end{array}$ & $\begin{array}{c}1 \\
0.96\end{array}$ & $\begin{array}{l}12 \\
17\end{array}$ & $\begin{array}{l}27 \\
26\end{array}$ & $\begin{array}{l}2.12 \\
1.44\end{array}$ & $\begin{array}{l}0.94 \\
2.87\end{array}$ & & & [116] \\
\hline $\mathrm{SiO}_{2}$ & MO & $\mathrm{OA}$ & 20 & $\begin{array}{c}0 \mathrm{vol} \% \\
20 \mathrm{vol} \%\end{array}$ & $\begin{array}{l}81.01 \\
90.21\end{array}$ & $\begin{array}{c}1 \\
1.11\end{array}$ & $\begin{array}{l}135.4 \\
126.2\end{array}$ & $\begin{array}{c}1 \\
0.93\end{array}$ & $\begin{array}{l}12.95 \\
18.01\end{array}$ & $\begin{array}{c}16.3 \\
12.79\end{array}$ & $\begin{array}{l}1.93 \\
1.38\end{array}$ & $\begin{array}{l}1.53 \\
1.95\end{array}$ & & IEC 60897 & [99] \\
\hline
\end{tabular}


Table 5. Cont

\begin{tabular}{|c|c|c|c|c|c|c|c|c|c|c|c|c|c|c|c|}
\hline NP & BF & Surfactant & Size $(\mathrm{nm})$ & Concentrations & PL BDV & $\mathrm{PL} \mathbf{B D V}_{n f} / \mathrm{PL} \mathbf{B D V}_{b f}$ & NL BDV & $\mathrm{NL}_{\mathrm{BDV}}{ }_{n f} / \mathrm{NL} \mathrm{BDV}_{b f}$ & Time + & Time - & Stream + & Stream - & Comments & Standard & Ref. \\
\hline $\mathrm{Al}_{2} \mathrm{O}_{3}$ & MO & yes & $5-20$ & $\begin{array}{c}0 \mathrm{vol} \% \\
0.1425 \mathrm{vol} \%\end{array}$ & $\begin{array}{c}98.77 \\
87.3 \\
\end{array}$ & $\begin{array}{c}1 \\
0.88\end{array}$ & $\begin{array}{c}-156.56 \\
136.16\end{array}$ & $\begin{array}{c}1 \\
-0.87\end{array}$ & & & $\begin{array}{l}1.77 \\
2.01\end{array}$ & $\begin{array}{l}1.77 \\
1.45 \\
\end{array}$ & & IEC 60897 & [110] \\
\hline $\mathrm{ZnO}$ & MO & yes & $5-20$ & $\begin{array}{c}0 \mathrm{vol} \% \\
0.0475 \mathrm{vol} \%\end{array}$ & $\begin{array}{l}98.77 \\
95.46\end{array}$ & $\begin{array}{c}1 \\
0.97\end{array}$ & $\begin{array}{l}-156.56 \\
-102.67\end{array}$ & $\begin{array}{c}1 \\
0.65\end{array}$ & & & $\begin{array}{l}1.77 \\
1.05\end{array}$ & $\begin{array}{l}1.77 \\
1.31\end{array}$ & & IEC 60897 & [110] \\
\hline semiconductive & MO & - & $<20$ & $\begin{array}{c}0 \\
\text { Low } \\
\text { Medium } \\
\text { High }\end{array}$ & $\begin{array}{l}70 \\
86 \\
87 \\
94 \\
\end{array}$ & $\begin{array}{c}1 \\
1.229 \\
1.243 \\
1.343 \\
\end{array}$ & & & & & & & ASTM D3300 & [103] & \\
\hline \multirow[t]{2}{*}{$\mathrm{Fe}_{3} \mathrm{O}_{4}$} & $\begin{array}{l}\text { MO U60 } \\
\text { MO N10x } \\
\text { MO U60 } \\
\text { MO N10x }\end{array}$ & & - & $\begin{array}{l}0 \\
0 \\
X \\
X\end{array}$ & $\begin{array}{l}86 \\
88 \\
157 \\
156\end{array}$ & $\begin{array}{c}1 \\
1.023 \\
1.826 \\
1.814\end{array}$ & $\begin{array}{l}170 \\
177 \\
154 \\
173\end{array}$ & $\begin{array}{c}1 \\
1 \\
0.91 \\
0.98\end{array}$ & $\begin{array}{l}12 \\
16 \\
26 \\
25\end{array}$ & $\begin{array}{l}27 \\
23 \\
15 \\
17\end{array}$ & & & gap $2.5 \mathrm{~mm}$ & ASTM D3300 & \multirow[t]{2}{*}{ [73] } \\
\hline & $\begin{array}{l}\text { MO U60 } \\
\text { MO U60 }\end{array}$ & & & $\begin{array}{l}0 \\
\mathrm{X} \\
\end{array}$ & $\begin{array}{l}225 \\
390 \\
\end{array}$ & $\begin{array}{l}2.616 \\
4.535 \\
\end{array}$ & $\begin{array}{l}340 \\
321\end{array}$ & $\begin{array}{c}2 \\
1.89\end{array}$ & $\begin{array}{l}25 \\
46\end{array}$ & $\begin{array}{l}28 \\
32\end{array}$ & & & gap $55 \mathrm{~mm}$ & & \\
\hline $\mathrm{ZrO}_{2}$ & - & - & 50 & $\begin{array}{c}0 \mathrm{wt} \% \\
0.005 \mathrm{wt} \% \\
0.010 \mathrm{wt} \% \\
0.050 \mathrm{wt} \%\end{array}$ & $\begin{array}{l}34.13 \\
39.60 \\
38.59 \\
36.61\end{array}$ & $\begin{array}{l}1.000 \\
1.160 \\
1.131 \\
1.073\end{array}$ & & & & & & & $\begin{array}{c}\text { Indian } \\
\text { Standard (IS) }\end{array}$ & IS11697:1986 & [91] \\
\hline Insulation (metal oxide) & MO & - & 70 & $\begin{array}{c}0 \% \text { mass fr } \\
0.05 \% \text { mass fr }\end{array}$ & $\begin{array}{l}72.5 \\
77.5\end{array}$ & $\begin{array}{c}1 \\
1.07\end{array}$ & & & & & & & & IEC 60897 & [107] \\
\hline Semiconductive & TO & - & - & $\begin{array}{c}0 \mathrm{~g} / \mathrm{L} \\
0.05 \mathrm{~g} / \mathrm{L}\end{array}$ & $\begin{array}{l}72.5 \\
78.3 \\
\end{array}$ & $\begin{array}{c}1 \\
1.08 \\
\end{array}$ & & & & & & & & IEC 60897 & [107] \\
\hline Conductive & TO & - & - & $\begin{array}{c}0 \mathrm{~g} / \mathrm{L} \\
0.05 \mathrm{~g} / \mathrm{L}\end{array}$ & $\begin{array}{l}72.5 \\
73.3\end{array}$ & $\begin{array}{c}1 \\
1.01\end{array}$ & & & & & & & & IEC 60897 & [107] \\
\hline AlN & TO & $\mathrm{OA}$ & - & $\begin{array}{c}0 \mathrm{vol} \% \\
\text { OA } \\
0.079 \mathrm{vol} \% \\
0.127 \mathrm{vol} \% \\
0.159 \mathrm{vol} \%\end{array}$ & $\begin{array}{l}162 \\
154 \\
155 \\
170 \\
166\end{array}$ & $\begin{array}{c}1 \\
0.95 \\
0.96 \\
1.05 \\
1.03\end{array}$ & & & & & & & & & [108] \\
\hline
\end{tabular}




\section{Possible Mechanism}

The mechanism behind improvement of the breakdown voltage in nanofluids based on both mineral and ester oils is not well understood yet. Some researchers assigned this enhancement to creating an electrical double layer (EDL) around the nanoparticles suspended in base fluid, as shown in Figure 11 [83,92,101]. Free ions existing in base fluid are attracted to the surface of nanoparticles and due to electrostatic forces are immobilized. This part of EDL is called the compact layer, and the density of net charge in this region drops down with the increasing radius of the layer, reaching zero. Electrostatic interaction in this area is lower, and ions can be mobile, creating a diffuse layer. The charge carrier in nanofluids under an external electrical field are moving through the sample using the channel created in EDL, where carriers can be trapped and de-trapped by opposite charges, leading to slowing down of the carriers. In effect, higher external power is needed to create the conducting path between electrodes [101].

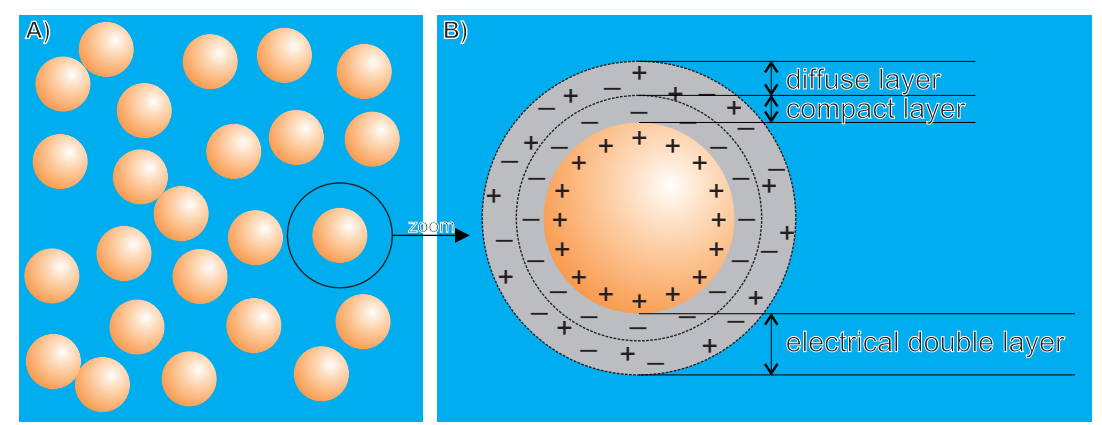

Figure 11. (A) Schematic view of nanoparticles dispersed in base fluid and (B) schematic view of the formation of an electrical double layer around a nanoparticle.

\section{Conclusions}

The present work provides an extensive review on the insulating properties of both mineral and natural ester insulating oils containing different types of nanoparticles with various concentrations. The most often studied nanoparticles are titanium oxides and iron oxide. The maximum enhancement in BDV was observed by Lee et al. [104,106] for magnetic nanofluids prepared using EFH-1 ferrofluid and transformer oil. On the other hand, the biggest deterioration in values of BDV was observed by Fontes [102] for MWCNT dispersed in mineral oil. Values of both positive and negative LI BDV are also strongly dependent on the inclusion of nanoparticles into transformer oils. The maximum enhancement in positive lightning impulse breakdown voltage was noticed by Segal et al. [73] for iron oxide dispersed in mineral oil, and it was 4.5 times. Furthermore, the maximum increase in negative impulse breakdown voltage was observed for the same material, and it was 2.0 times.

This overview of papers leads to a few conclusions about the factors affecting the values of breakdown voltage (BDV) and the lightning impulse breakdown voltage (LI BDV). First, it is obvious that the concentration of nanoparticles in transformer oils has a strong effect on BDV values, and this effect is not unequivocal. As many researchers have revealed [97,104,105], the increase in the load of nanoparticles in the base fluid causes an increase in BDV. On the other hand, there are nanofluids that exhibit an increase in BDV only up to some concentration, above which a decrease in BDV is observed $[77,86,90,95]$. In some cases, the addition of nanoparticles causes the completely opposite effect: decreasing BDV below a pure base fluid [73,85,102]. Furthermore, the content of moisture is important for the good insulating properties of transformer oil-based nanofluids as Bakrutheen et al. [85] and Jin et al. [93-95] reported. The lifetime of nanofluids is not without significance, and it was investigated by Yue-fan et al. [83] and Rafiq et al. [76]. To improve the stability of nanofluids, researchers often use surfactants. One of the most used surfactants is oleic acid, but from the point of view of the AC BDV values of transformer oil-based nanofluids, the most effective 
surfactant is CTAB. As was presented in this review paper, nanoparticles might be used to improve the insulating properties of transformers. Unfortunately, at the moment, the mechanisms occurring in transformer oils containing nanoparticles during breakdown voltage tests are not fully understood; additionally, a lack of a unified method of preparation and testing of the BDV of nanofluids and concentration representation cause problems with the comparison of the results obtained by different researcher, so further work in both the experimental and the theoretical field of this issue should be considered, taking into account standardized rules of sample preparation, measurement methods and data representation.

Author Contributions: All authors contributed equally.

Funding: This research received no external funding.

Conflicts of Interest: The authors declare no conflict of interest.

\section{Abbreviations}

The following abbreviations are used in this manuscript:

$\begin{array}{ll}\text { AB } & \text { alkyl benzene } \\ \text { AC } & \text { alternating current } \\ \text { ASTM } & \text { The American Society for Testing and Materials } \\ \text { BDV } & \text { breakdown voltage }(\mathrm{kV}) \\ \text { BF } & \text { base fluid } \\ \text { CCO } & \text { coconut oil } \\ \text { CO } & \text { corn oil } \\ \text { CTAB } & \text { hexadecyl trimethyl ammonium Bromide } \\ \text { DC } & \text { direct current } \\ \text { IEC } & \text { International Electrotechnical Commission } \\ \text { LI } & \text { lightning impulse } \\ \text { MO } & \text { mineral oil } \\ \text { NE } & \text { natural ester oil } \\ \text { NF } & \text { nanofluid } \\ \text { NLI } & \text { negative lightning impulse } \\ \text { NP } & \text { nanoparticle } \\ \text { OA } & \text { oleic acid } \\ \text { ODA } & \text { octadecanoic acid } \\ \text { PE } & \text { palm ester } \\ \text { PFAE } & \text { palm fatty acid ester } \\ \text { PLI } & \text { positive lightning impulse } \\ \text { PV/T } & \text { hybrig photovoltaic and thermal solar system } \\ \text { SA } & \text { stearic acid } \\ \text { SBE } & \text { soybean ester } \\ \text { SDBS } & \text { sodium dodecyl benzene sulfonate } \\ \text { SO } & \text { silicon oil } \\ \text { TO } & \text { transformer oil } \\ \text { VO } & \text { vegetable oil } \\ & \end{array}$

\section{References}

1. Choi, S.U.; Eastman, J.A. Enhancing thermal conductivity of fluids with nanoparticles. ASME-Publ. 1995, 231, 99-106.

2. Haddad, Z.; Abid, C.; Oztop, H.F.; Mataoui, A. A review on how the researchers prepare their nanofluids. Int. J. Therm. Sci. 2014, 76, 168-189. [CrossRef]

3. Hwang, Y.; Lee, J.K.; Lee, J.K.; Jeong, Y.M.; Cheong, S.I.; Ahn, Y.C.; Kim, S.H. Production and dispersion stability of nanoparticles in nanofluids. Powder Technol. 2008, 186, 145-153. [CrossRef] 
4. Khalil, M.; Jan, B.M.; Tong, C.W.; Berawi, M.A. Advanced nanomaterials in oil and gas industry: Design, application and challenges. Appl. Energy 2017, 191, 287-310. [CrossRef]

5. Yu, W.; Xie, H. A review on nanofluids: Preparation, stability mechanisms, and applications. J. Nanomater. 2012, 2012, 1. [CrossRef]

6. Sundar, L.S.; Sharma, K.; Singh, M.K.; Sousa, A. Hybrid nanofluids preparation, thermal properties, heat transfer and friction factor-A review. Renew. Sustain. Energy Rev. 2017, 68, 185-198. [CrossRef]

7. Fan, J.; Wang, L. Review of heat conduction in nanofluids. J. Heat Transf. 2011, 133, 040801. [CrossRef]

8. Wang, X.Q.; Mujumdar, A.S. Heat transfer characteristics of nanofluids: A review. Int. J. Therm. Sci. 2007, 46, 1-19. [CrossRef]

9. Trisaksri, V.; Wongwises, S. Critical review of heat transfer characteristics of nanofluids. Renew. Sustain. Energy Rev. 2007, 11, 512-523. [CrossRef]

10. Sergis, A.; Hardalupas, Y. Anomalous heat transfer modes of nanofluids: A review based on statistical analysis. Nanoscale Res. Lett. 2011, 6, 391. [CrossRef] [PubMed]

11. Thomas, S.; Sobhan, C.B.P. A review of experimental investigations on thermal phenomena in nanofluids. Nanoscale Res. Lett. 2011, 6, 377. [CrossRef] [PubMed]

12. Ramesh, G.; Prabhu, N.K. Review of thermo-physical properties, wetting and heat transfer characteristics of nanofluids and their applicability in industrial quench heat treatment. Nanoscale Res. Lett. 2011, 6, 334. [CrossRef] [PubMed]

13. Hussien, A.A.; Abdullah, M.Z.; Mohad A.A.N. Single-phase heat transfer enhancement in micro/minichannels using nanofluids: Theory and applications. Appl. Energy 2016, 164, 733-755. [CrossRef]

14. Kleinstreuer, C.; Feng, Y. Experimental and theoretical studies of nanofluid thermal conductivity enhancement: A review. Nanoscale Res. Lett. 2011, 6, 229. [CrossRef] [PubMed]

15. Wen, D.; Lin, G.; Vafaei, S.; Zhang, K. Review of nanofluids for heat transfer applications. Particuology 2009, 7, 141-150. [CrossRef]

16. Das, S.K.; Choi, S.U.; Patel, H.E. Heat transfer in nanofluids-a review. Heat Transf. Eng. 2006, $27,3-19$. [CrossRef]

17. Daungthongsuk, W.; Wongwises, S. A critical review of convective heat transfer of nanofluids. Renew. Sustain. Energy Rev. 2007, 11, 797-817. [CrossRef]

18. Özerinç, S.; Kakaç, S.; Yazıcıoğlu, A.G. Enhanced thermal conductivity of nanofluids: A state-of-the-art review. Microfluid. Nanofluid. 2010, 8, 145-170. [CrossRef]

19. Khalaj, A.H.; Halgamuge, S.K. A Review on efficient thermal management of air-and liquid-cooled data centers: From chip to the cooling system. Appl. Energy 2017, 205, 1165-1188. [CrossRef]

20. Younes, H.; Christensen, G.; Li, D.; Hong, H.; Ghaferi, A.A. Thermal conductivity of nanofluids. J. Nanofluids 2015, 4, 107-132. [CrossRef]

21. Lee, J.H.; Lee, S.H.; Choi, C.; Jang, S.; Choi, S. A review of thermal conductivity data, mechanisms and models for nanofluids. Int. J. Micro-Nano Scale Trans. 2011. [CrossRef]

22. Murshed, S.S.; de Castro, C.N. Conduction and convection heat transfer characteristics of ethylene glycol based nanofluids-A review. Appl. Energy 2016, 184, 681-695. [CrossRef]

23. Aguilar, T.; Navas, J.; Sánchez-Coronilla, A.; Martín, E.I.; Gallardo, J.J.; Martínez-Merino, P.; Gómez-Villarejo, R.; Piñero, J.C.; Alcántara, R.; Fernández-Lorenzo, C. Investigation of enhanced thermal properties in NiO-based nanofluids for concentrating solar power applications: A molecular dynamics and experimental analysis. Appl. Energy 2018, 211, 677-688. [CrossRef]

24. Chen, H.; Ding, Y. Heat transfer and rheological behavior of nanofluids-A review. In Advances in Transport Phenomena; Springer: New York, NY, USA, 2009; pp. 135-177.

25. Aladag, B.; Halelfadl, S.; Doner, N.; Maré, T.; Duret, S.; Estellé, P. Experimental investigations of the viscosity of nanofluids at low temperatures. Appl. Energy 2012, 97, 876-880. [CrossRef]

26. Sundar, L.S.; Sharma, K.; Naik, M.; Singh, M.K. Empirical and theoretical correlations on viscosity of nanofluids: A review. Renew. Sustain. Energy Rev. 2013, 25, 670-686. [CrossRef]

27. Meyer, J.P.; Adio, S.A.; Sharifpur, M.; Nwosu, P.N. The viscosity of nanofluids: A review of the theoretical, empirical, and numerical models. Heat Transf. Eng. 2016, 37, 387-421. [CrossRef]

28. Murshed, S.S.; Estellé, P. A state of the art review on viscosity of nanofluids. Renew. Sustain. Energy Rev. 2017, 76, 1134-1152. [CrossRef] 
29. Masoumi, N.; Sohrabi, N.; Behzadmehr, A. A new model for calculating the effective viscosity of nanofluids. J. Phys. D Appl. Phys. 2009, 42, 055501. [CrossRef]

30. Bashirnezhad, K.; Bazri, S.; Safaei, M.R.; Goodarzi, M.; Dahari, M.; Mahian, O.; Dalkılıça, A.S.; Wongwises, S. Viscosity of nanofluids: A review of recent experimental studies. Int. Commun. Heat Mass Transf. 2016, 73, 114-123. [CrossRef]

31. Hossain, M.S.; Saidur, R.; Sabri, M.F.M.; Said, Z.; Hassani, S. Spotlight on available optical properties and models of nanofluids: A review. Renew. Sustain. Energy Rev. 2015, 43, 750-762. [CrossRef]

32. Philip, J.; Laskar, J.M. Optical properties and applications of ferrofluids-A review. J. Nanofluids 2012, 1, 3-20. [CrossRef]

33. Voitylov, A.; Veso, O.; Petrov, M.; Rolich, V.; Trusov, A.; Vojtylov, V. Light refraction in aqueous suspensions of diamond particles. Coll. Surf. A Physicochem. Eng. Asp. 2018, 538, 417-422. [CrossRef]

34. Estellé, P.; Cabaleiro, D.; Żyła, G.; Lugo, L.; Murshed, S.S. Current trends in surface tension and wetting behavior of nanofluids. Renew. Sustain. Energy Rev. 2018, 94, 931-944. [CrossRef]

35. Baby, T.T.; Ramaprabhu, S. Investigation of thermal and electrical conductivity of graphene based nanofluids. J. Appl. Phys. 2010, 108, 124308. [CrossRef]

36. Ganguly, S.; Sikdar, S.; Basu, S. Experimental investigation of the effective electrical conductivity of aluminum oxide nanofluids. Powder Technol. 2009, 196, 326-330. [CrossRef]

37. Shoghl, S.N.; Jamali, J.; Moraveji, M.K. Electrical conductivity, viscosity, and density of different nanofluids: An experimental study. Exp. Therm. Fluid Sci. 2016, 74, 339-346. [CrossRef]

38. Sarojini, K.K.; Manoj, S.V.; Singh, P.K.; Pradeep, T.; Das, S.K. Electrical conductivity of ceramic and metallic nanofluids. Coll. Surf. A Physicochem. Eng. Asp. 2013, 417, 39-46. [CrossRef]

39. Żyła, G.; Fal, J.; Estellé, P. Thermophysical and dielectric profiles of ethylene glycol based titanium nitride (TiN-EG) nanofluids with various size of particles. Int. J. Heat Mass Transf. 2017, 113, 1189-1199. [CrossRef]

40. Kulkarni, D.P.; Das, D.K.; Vajjha, R.S. Application of nanofluids in heating buildings and reducing pollution. Appl. Energy 2009, 86, 2566-2573. [CrossRef]

41. Taylor, R.; Coulombe, S.; Otanicar, T.; Phelan, P.; Gunawan, A.; Lv, W.; Rosengarten, G.; Prasher, R.; Tyagi, H. Small particles, big impacts: A review of the diverse applications of nanofluids. J. Appl. Phys. 2013, 113, 011301. [CrossRef]

42. Hussein, A.; Kadirgama, K.; Noor, M. Nanoparticles suspended in ethylene glycol thermal properties and applications: An overview. Renew. Sustain. Energy Rev. 2016, 69, 1324-1330. [CrossRef]

43. Bashirnezhad, K.; Ghavami, M.; Alrashed, A.A. Experimental investigations of nanofluids convective heat transfer in different flow regimes: A review. J. Mol. Liq. 2017. [CrossRef]

44. Mahian, O.; Kianifar, A.; Kalogirou, S.A.; Pop, I.; Wongwises, S. A review of the applications of nanofluids in solar energy. Int. J. Heat Mass Transf. 2013, 57, 582-594. [CrossRef]

45. Kim, H.; Kim, J.; Cho, H. Experimental study on performance improvement of U-tube solar collector depending on nanoparticle size and concentration of $\mathrm{Al}_{2} \mathrm{O}_{3}$ nanofluid. Energy 2017, 118, 1304-1312. [CrossRef]

46. Loni, R.; Asli-ardeh, E.A.; Ghobadian, B.; Kasaeian, A.; Gorjian, S. Thermodynamic analysis of a solar dish receiver using different nanofluids. Energy 2017, 133, 749-760. [CrossRef]

47. Hassani, S.; Taylor, R.A.; Mekhilef, S.; Saidur, R. A cascade nanofluid-based PV/T system with optimized optical and thermal properties. Energy 2016, 112, 963-975. [CrossRef]

48. Mahian, O.; Kianifar, A.; Heris, S.Z.; Wen, D.; Sahin, A.Z.; Wongwises, S. Nanofluids effects on the evaporation rate in a solar still equipped with a heat exchanger. Nano Energy 2017, 36, 134-155. [CrossRef]

49. Huminic, G.; Huminic, A. Application of nanofluids in heat exchangers: A review. Renew. Sustain. Energy Rev. 2012, 16, 5625-5638. [CrossRef]

50. Hosseinian, A.; Isfahani, A.M.; Shirani, E. Experimental investigation of surface vibration effects on increasing the stability and heat transfer coeffcient of MWCNTs-water nanofluid in a flexible double pipe heat exchanger. Exp. Therm. Fluid Sci. 2018, 90, 275-285. [CrossRef]

51. Xing, M.; Yu, J.; Wang, R. Performance of a vertical closed pulsating heat pipe with hydroxylated MWNTs nanofluid. Int. J. Heat Mass Transf. 2017, 112, 81-88. [CrossRef]

52. Sarafraz, M.; Nikkhah, V.; Madani, S.; Jafarian, M.; Hormozi, F. Low-frequency vibration for fouling mitigation and intensification of thermal performance of a plate heat exchanger working with $\mathrm{CuO} /$ water nanofluid. Appl. Therm. Eng. 2017, 121, 388-399. [CrossRef] 
53. Shahrul, I.; Mahbubul, I.; Saidur, R.; Sabri, M. Experimental investigation on $\mathrm{Al}_{2} \mathrm{O}_{3}-\mathrm{W}, \mathrm{SiO}_{2}-\mathrm{W}$ and $\mathrm{ZnO}-\mathrm{W}$ nanofluids and their application in a shell and tube heat exchanger. Int. J. Heat Mass Transf. 2016, 97, 547-558. [CrossRef]

54. Zhang, J.; Wang, F.; Li, J.; Ran, H.; Li, X.; Fu, Q. Breakdown Voltage and Its Influencing Factors of Thermally Aged Oil-Impregnated Paper at Pulsating DC Voltage. Energies 2017, 10, 1411. [CrossRef]

55. Li, J.; He, Z.; Grzybowski, S. Electrical aging lifetime model of oil-impregnated paper under pulsating DC voltage influenced by temperature. IEEE Trans. Dielectr. Electr. Insul. 2013, 20, 1992-1997. [CrossRef]

56. Rainer, W.; Peter, B. Application Note an 16-002. High Voltage Testing; Technical Report; Semikron: Nuremberg, Germany, 2016.

57. Gray, J. Application Note: Improving Safety and Performance with DC Dielectric Testing. Available online: http:/ / www.gigavac.com/application-notes/high-voltage-relays/dielectric-testing (accessed on 22 October 2018).

58. Primo, V.A.; Garcia, B.; Albarracin, R. Improvement of transformer liquid insulation using nanodielectric fluids: A review. IEEE Electr. Insul. Mag. 2018, 34, 13-26. [CrossRef]

59. Testing, T.A.S. ASTM D1816-12S Tandard Test Method for Dielectric Breakdown Voltage of Insulating Liquids Using VDE Electrodes; Technical Report; The American Society for Testing and Materials: West Conshohocken, PA, USA, 2012.

60. Testing, T.A.S. ASTM D877 Standard Test Method for Dielectric Breakdown Voltage Of Insulating Liquids Using Disk Electrodes; Technical Report; The American Society for Testing and Materials: West Conshohocken, PA, USA, 2013.

61. Testing, T.A.S. ASTM D6871-17 Standard Specification for Natural (Vegetable Oil) Ester Fluids Used in Electrical Apparatus; Technical Report; The American Society for Testing and Materials: West Conshohocken, PA, USA, 2017.

62. Commission, I.E. IEC 60156 Insulating Liquids-Determination of the Breakdown Voltage at Power Frequency-Test Method; Technical Report; International Electrotechnical Commission: Geneva, Switzerland, 1995.

63. Testing, T.A.S. ASTM D3300 Standard Test Method for Dielectric Breakdown Voltage of Insulating Oils of Petroleum Origin Under Impulse Conditions; Technical Report; The American Society for Testing and Materials: West Conshohocken, PA, USA, 2012.

64. Commission, I.E. IEC 60897 Methods for the Determination of the Lightning Breakdown Voltage of Insulating Liquids; Technical Report; International Electrotechnical Commission: Geneva, Switzerland, 1987.

65. Du, B.; Li, J.; Wang, B.M.; Zhang, Z.T. Preparation and breakdown strength of $\mathrm{Fe}_{3} \mathrm{O}_{4}$ nanofluid based on transformer oil. In Proceedings of the 2012 International Conference on High Voltage Engineering and Application (ICHVE), Shanghai, China, 17-20 September 2012; pp. 311-313.

66. Li, J.; Zhang, Z.; Zou, P.; Grzybowski, S.; Zahn, M. Preparation of a vegetable oil-based nanofluid and investigation of its breakdown and dielectric properties. Electr. Insul. Mag. 2012, 28, 43-50. [CrossRef]

67. Peppas, G.; Charalampakos, V.; Pyrgioti, E.; Polydoropoulou, E. Influence of surface modified $\mathrm{Fe}_{3} \mathrm{O}_{4}$ nanoparticles on the dielectric properties of natural ester based nanofluid. In Proceedings of the 19th International Symposium on High Voltage Engineerin (ISH 2015), Pilsen, Czech Republic, 23-28 August 2015.

68. Mohamad, M.; Zainuddin, H.; Ghani, S.; Chairul, I. Breakdown and partial discharge performance of Palm Fatty Acid Ester (PFAE) oil-based $\mathrm{Fe}_{3} \mathrm{O}_{4}$ nanofluids. In Proceedings of the 2016 IEEE International Conference on Power and Energy (PECon), Melaka, Malaysia, 28-29 November 2016; pp. 317-321.

69. Rafiq, M.; Li, C.; Ge, Y.; Lv, Y.; Yi, K. Effect of $\mathrm{Fe}_{3} \mathrm{O}_{4}$ nanoparticle concentrations on dielectric property of transformer oil. In Proceedings of the 2016 IEEE International Conference on High Voltage Engineering and Application (ICHVE), Chengdu, China, 19-22 September 2016.

70. Rafiq, M.; Li, C.; Lv, Y.; Yi, K.; Sun, Q. Breakdown characteristics of mineral oil based magnetic nanofluids. In Proceedings of the 2016 IEEE International Conference on High Voltage Engineering and Application (ICHVE), Chengdu, China, 19-22 September 2016; pp. 1-4.

71. Zou, P.; Li, J.; Sun, C.X.; Zhang, Z.T.; Liao, R.J. Dielectric properties and electrodynamic process of natural ester-based insulating nanofluid. Mod. Phys. Lett. B 2011, 25, 2021-2031. [CrossRef]

72. Kudelcik, J.; Bury, P.; Kopcansky, P.; Timko, M. Dielectric breakdown in mineral oil ITO 100 based magnetic fluid. Phys. Procedia 2010, 9, 78-81. [CrossRef] 
73. Segal, V.; Hjortsberg, A.; Rabinovich, A.; Nattrass, D.; Raj, K. AC (60 Hz) and impulse breakdown strength of a colloidal fluid based on transformer oil and magnetite nanoparticles. In Proceedings of the Conference Record of the 1998 IEEE International Symposium on Electrical Insulation, Arlington, VA, USA, 7-10 June 1998; Volume 2, pp. 619-622.

74. Peppas, G.D.; Bakandritsos, A.; Charalampakos, V.P.; Pyrgioti, E.C.; Tucek, J.; Zboril, R.; Gonos, I.F. Ultrastable natural ester-based nanofluids for high voltage insulation applications. ACS Appl. Mater. Interfaces 2016, 8, 25202-25209. [CrossRef] [PubMed]

75. Du, Y.; Lv, Y.; Li, C.; Chen, M.; Zhong, Y.; Zhou, J.; Li, X.; Zhou, Y. Effect of semiconductive nanoparticles on insulating performances of transformer oil. IEEE Trans. Dielectr. Electr. Insul. 2012, 19, 770-776.

76. Rafiq, M.; Wang, W.; Ma, K.; Zhou, Y.; Wang, Q.; Li, C.; Lv, Y. Insulating and aging properties of transformer oil-based $\mathrm{TiO}_{2}$ nanofluids. In Proceedings of the 2014 IEEE Conference on Electrical Insulation and Dielectric Phenomena (CEIDP), Des Moines, IA, USA, 19-22 October 2014; pp. 457-461.

77. Du, Y.F.; Lv, Y.Z.; Wang, F.C.; Li, X.X.; Li, C.R. Effect of $\mathrm{TiO}_{2}$ nanoparticles on the breakdown strength of transformer oil. In Proceedings of the Conference Record of the 2010 IEEE International Symposium on Electrical Insulation (ISEI), San Diego, CA, USA, 6-9 June 2010; pp. 1-3.

78. Lv, Y.Z.; Li, X.X.; Du, Y.F.; Wang, F.C.; Li, C.R. Preparation and breakdown strength of $\mathrm{TiO}_{2}$ fluids based on transformer oil. In Proceedings of the 2010 Annual Report Conference on Electrical Insulation and Dielectic Phenomena, West Lafayette, IN, USA, 17-20 October 2010; pp. 1-3.

79. Du, Y.; Lv, Y.; Zhou, J.; Li, X.; Li, C. Breakdown properties of transformer oil-based $\mathrm{TiO}_{2}$ nanofluid. In Proceedings of the 2010 Annual Report Conference on Electrical Insulation and Dielectic Phenomena, West Lafayette, IN, USA, 17-20 October 2010; pp. 1-4.

80. Du, Y.; Lv, Y.; Li, C.; Chen, M.; Zhou, J.; Li, X.; Zhou, Y.; Tu, Y. Effect of electron shallow trap on breakdown performance of transformer oil-based nanofluids. J. Appl. Phys. 2011, 110, 104104. [CrossRef]

81. Lv, Y.Z.; Wang, L.F.; Li, X.X.; Du, Y.F.; Zhou, J.Q.; Li, C.R. Experimental investigation of breakdown strength of mineral oil-based nanofluids. In Proceedings of the 2011 IEEE International Conference on Dielectric Liquids, Trondheim, Norway, 26-30 June 2011; pp. 1-3.

82. Chen, M.T.; Du, Y.F.; Lv, Y.Z.; Zhou, J.Q.; Li, X.X. Effect of nanoparticles on the dielectric strength of aged transformer oil. In Proceedings of the 2011 Annual Report Conference on Electrical Insulation and Dielectric Phenomena, Cancun, Mexico, 16-19 October 2011; pp. 664-667.

83. Du, Y.F.; Lv, Y.Z.; Zhou, J.Q.; Chen, M.T.; Li, X.X. Effect of ageing on insulating property of mineral oil-based $\mathrm{TiO}_{2}$ nanofluids. In Proceedings of the 2011 IEEE International Conference on Dielectric Liquids, Trondheim, Norway, 26-30 June 2011; pp. 1-4.

84. Mansour, D.E.A.; Atiya, E.G.; Khattab, R.M.; Azmy, A.M. Effect of titania nanoparticles on the dielectric properties of transformer oil-based nanofluids. In Proceedings of the 2012 Annual Report Conference on Electrical Insulation and Dielectric Phenomena, Montreal, QC, Canada, 14-17 October 2012; pp. 295-298.

85. Bakrutheen, M.; Karthik, R.; Madavan, R. Investigation of critical parameters of insulating mineral oil using semiconductive nanoparticles. In Proceedings of the 2013 International Conference on Circuits, Power and Computing Technologies (ICCPCT), Nagercoil, India, 20-21 March 2013; pp. 294-299.

86. Hanai, M.; Hosomi, S.; Kojima, H.; Hayakawa, N.; Okubo, H. Dependence of $\mathrm{TiO}_{2}$ and $\mathrm{ZnO}$ nanoparticle concentration on electrical insulation characteristics of insulating oil. In Proceedings of the 2013 Annual Report Conference on Electrical Insulation and Dielectric Phenomena, Shenzhen, China, 20-23 October 2013; pp. 780-783.

87. Zhong, Y.; Lv, Y.; Li, C.; Du, Y.; Chen, M.; Zhang, S.; Zhou, Y.; Chen, L. Insulating properties and charge characteristics of natural ester fluid modified by $\mathrm{TiO}_{2}$ semiconductive nanoparticles. IEEE Trans. Dielectr. Electr. Insul. 2013, 20, 135-140. [CrossRef]

88. Hu, Z.F.; Ma, K.B.; Wang, W.; Rafiq, M.; Zhou, Y.; Wang, Q.; Du, Y.F.; Li, C.R.; Lv, Y.Z. Thermal aging properties of transformer oil-based $\mathrm{TiO}_{2}$ nanofluids. In Proceedings of the 2014 IEEE 18th International Conference on Dielectric Liquids (ICDL), Bled, Slovenia, 29 June-3 July 2014.

89. Atiya, E.G.; Mansour, D.E.A.; Khattab, R.M.; Azmy, A.M. Dispersion behavior and breakdown strength of transformer oil filled with $\mathrm{TiO}_{2}$ nanoparticles. IEEE Trans. Dielectr. Electr. Insul. 2015, 22, $2463-2472$. [CrossRef]

90. Saenkhumwong, W.; Suksri, A. The improved dielectric properties of natural ester oil by using $\mathrm{ZnO}$ and $\mathrm{TiO}_{2}$ nanoparticles. Eng. Appl. Sci. Res. 2017, 44, 148-153. 
91. Pugazhendhi, S.C. Experimental evaluation on dielectric and thermal characteristics of nano filler added transformer oil. In Proceedings of the 2012 International Conference on High Voltage Engineering and Application, Shanghai, China, 17-20 September 2012; pp. 207-210.

92. Mansour, D.E.A.; Elsaeed, A.M.; Izzularab, M.A. The role of interfacial zone in dielectric properties of transformer oil-based nanofluids. IEEE Trans. Dielectr. Electr. Insul. 2016, 23, 3364-3372. [CrossRef]

93. Jin, H.; Andritsch, T.; Morshuis, P.; Smit, J. AC breakdown voltage and viscosity of mineral oil based $\mathrm{SiO}_{2}$ nanofluids. In Proceedings of the 2012 Annual Report Conference on Electrical Insulation and Dielectric Phenomena, Montreal, QC, Canada, 14-17 October 2012; pp. 902-905.

94. Jin, H.; Andritsch, T.; Tsekmes, I.; Kochetov, R.; Morshuis, P.; Smit, J. Properties of mineral oil based silica nanofluids. IEEE Trans. Dielectr. Electr. Insul. 2014, 21, 1100-1108.

95. Jin, H.; Morshuis, P.H.; Smit, J.J.; Andritsch, T. The effect of surface treatment of silica nanoparticles on the breakdown strength of mineral oil. In Proceedings of the 2014 IEEE 18th International Conference on Dielectric Liquids (ICDL), Bled, Slovenia, 29 June-3 July 2014.

96. Rafiq, M.; Khan, D.; Ali, M. Insulating properties of transformer oil-based silica nanofluids. In Proceedings of the 2015 Power Generation System and Renewable Energy Technologies (PGSRET), Islamabad, Pakistan, 10-11 June 2015; pp. 1-3.

97. Karthik, R.; Raymon, A. Effect of silicone oxide nano particles on dielectric characteristics of natural ester. In Proceedings of the 2016 IEEE International Conference on High Voltage Engineering and Application (ICHVE), Chengdu, China, 19-22 September 2016.

98. Prasad, D.; Chandrasekar, S. Investigations on Dielectric Performance Characteristics of Natural Ester based Nano-Fluids for Power Transformer Applications. Asian J. Res. Soc. Sci. Hum. 2016, 6, 1146-1157. [CrossRef]

99. Rafiq, M.; Li, C.; Du, Q.; Lv, Y.; Yi, K. Effect of $\mathrm{SiO}_{2}$ nanoparticle on insulating breakdown properties of transformer oil. In Proceedings of the 2016 IEEE International Conference on High Voltage Engineering and Application (ICHVE), Chengdu, China, 19-22 September 2016.

100. Dong, M.; Dai, J.; Li, Y.; Xie, J.; Ren, M.; Dang, Z. Insight into the dielectric response of transformer oil-based nanofluids. AIP Adv. 2017, 7, 025307. [CrossRef]

101. Jianzhuo, D.; Ming, D.; Li, W.; Yang, L.; Jianyi, W. Study on AC breakdown and broadband dielectric response properties of transformer oil-based nanofluids. In Proceedings of the 2016 International Conference on Condition Monitoring and Diagnosis (CMD), Xi'an, China, 25-28 September 2016; pp. $24-27$.

102. Fontes, D.H.; Ribatski, G.; Bandarra Filho, E.P. Experimental evaluation of thermal conductivity, viscosity and breakdown voltage AC of nanofluids of carbon nanotubes and diamond in transformer oil. Diam. Relat. Mater. 2015, 58, 115-121. [CrossRef]

103. Zhou, J.Q.; Du, Y.F.; Chen, M.T.; Li, C.R.; Li, X.X. AC and lightning breakdown strength of transformer oil modified by semiconducting nanoparticles. In Proceedings of the 2011 Annual Report Conference on Electrical Insulation and Dielectric Phenomena, Cancun, Mexico, 16-19 October 2011; pp. 652-654.

104. Lee, J.C.; Kim, W.Y. Experimental study on the dielectric breakdown voltage of the insulating oil mixed with magnetic nanoparticles. Phys. Procedia 2012, 32, 327-334. [CrossRef]

105. Lee, J.C.; Seo, H.S.; Kim, Y.J. The increased dielectric breakdown voltage of transformer oil-based nanofluids by an external magnetic field. Int. J. Therm. Sci. 2012, 29-33. [CrossRef]

106. Lee, J.C.; Lee, W.H.; Lee, S.H.; Lee, S. Positive and negative effects of dielectric breakdown in transformer oil based magnetic fluids. Mater. Res. Bull. 2012, 47, 2984-2987. [CrossRef]

107. Lv, Y.; Wang, W.; Ma, K.; Zhang, S.; Zhou, Y.; Li, C.; Wang, Q. Nanoparticle effect on dielectric breakdown strength of transformer oil-based nanofluids. In Proceedings of the 2013 Annual Report Conference on Electrical Insulation and Dielectric Phenomena, Shenzhen, China, 20-23 October 2013; pp. 680-682.

108. Liu, D.; Zhou, Y.; Yang, Y.; Zhang, L.; Jin, F. Characterization of high performance AIN nanoparticle-based transformer oil nanofluids. IEEE Trans. Dielectr. Electr. Insul. 2016, 23, 2757-2767. [CrossRef]

109. Jin, H.; Andritsch, T.; Morshuis, P.; Smit, J. AC breakdown voltage and viscosity of mineral oil based fullerene nanofluids. In Proceedings of the 2013 Annual Report Conference on Electrical Insulation and Dielectric Phenomena, Shenzhen, China, 20-23 October 2013; pp. 703-706.

110. Liu, R.; Pettersson, L.A.; Auletta, T.; Hjortstam, O. Fundamental research on the application of nano dielectrics to transformers. In Proceedings of the 2011 Annual Report Conference on Electrical Insulation and Dielectric Phenomena (CEIDP), Cancun, Mexico, 16-19 October 2011; pp. 423-427. 
111. Li, J.; Zhang, Z.T.; Zou, P.; Du, B.; Liao, R.J. Lightning impulse breakdown characteristics and electrodynamic process of insulating vegetable oil-based nanofluid. Mod. Phys. Lett. B 2012, 26, 1250095. [CrossRef]

112. Ghasemi, J.; Jafarmadar, S.; Nazari, M. Effect of magnetic nanoparticles on the lightning impulse breakdown voltage of transformer oil. J. Magn. Magn. Mater. 2015, 389, 148-152. [CrossRef]

113. Yang, Q.; Yu, F.; Sima, W.; Zahn, M. Space charge inhibition effect of nano- $\mathrm{Fe}_{3} \mathrm{O}_{4}$ on improvement of impulse breakdown voltage of transformer oil based on improved Kerr optic measurements. AIP Adv. 2015, 5, 097207. [CrossRef]

114. Shi, J.; Yang, Q.; Sima, W.; Liao, L.; Huang, S.; Zahn, M. Space charge dynamics investigation based on Kerr electro-optic measurements and processing of CCD images. IEEE Trans. Dielectr. Electr. Insul. 2013, 20, 601-611.

115. Lv, Y.; Rafiq, M.; Li, C.; Shan, B. Study of Dielectric Breakdown Performance of Transformer Oil Based Magnetic Nanofluids. Energies 2017, 10, 1025.

116. Ramu, T.; Keshavan, B.; Murthy, K.B. Application of a class of nano fluids to improve the loadability of power transformers. In Proceedings of the 2012 IEEE 10th International Conference on the Properties and Applications of Dielectric Materials (ICPADM), Bangalore, India, 24-28 July 2012; pp. 1-6.

117. Li, J.; Liao, R.; Yang, L. Investigation of natural ester based liquid dielectrics and nanofluids. In Proceedings of the 2012 International Conference on High Voltage Engineering and Application, Shanghai, China, 17-20 September 2012; pp. 16-21.

(C) 2018 by the authors. Licensee MDPI, Basel, Switzerland. This article is an open access article distributed under the terms and conditions of the Creative Commons Attribution (CC BY) license (http://creativecommons.org/licenses/by/4.0/). 